Paulo Henrique Pereira Gonçalves

\title{
Análise da variabilidade genética de uma pequena população de Frieseomelitta varia (Hymenoptera, Apidae, Meliponini) por meio de análise do DNA mitocondrial, microssatélites e morfometria geométrica das asas
}

Analysis of the genetic variability of a small population of Frieseomelitta varia (Hymenoptera, Apidae, Meliponini) through mitochondrial DNA analysis, microsatellites and geometric morphometry of wings

São Paulo 


\section{Paulo Henrique Pereira Gonçalves}

\section{Análise da variabilidade genética de uma pequena população de Frieseomelitta varia (Hymenoptera, Apidae, Meliponini) por meio de análise do DNA mitocondrial, microssatélites e morfometria geométrica das asas}

Analysis of the genetic variability of a small population of Frieseomelitta varia

(Hymenoptera, Apidae, Meliponini) through mitochondrial DNA analysis, microsatellites and geometric morphometry of wings

Dissertação apresentada ao Instituto de Biociências da Universidade de São Paulo para obtenção de Título de Mestre em Ciências, na Área de Biologia/Genética.

Orientadora:

Profa. Dra. Maria Cristina Arias

São Paulo 
Gonçalves, Paulo Henrique Pereira

Análise da variabilidade genética de uma pequena população de Frieseomelitta varia (Hymenoptera, Apidae, Meliponini) por meio de análise do DNA mitocondrial, microssatélites e morfometria geométrica das asas

$$
\text { ix }+140 \text { páginas }
$$

Dissertação (Mestrado) - Instituto de Biociências da Universidade de São Paulo. Departamento de Genética e Biologia Evolutiva.

1. Frieseomelitta varia 2. DNA mitocondrial 3. Microssatélites 4. Morfometria Geométrica de asas

I. Universidade de São Paulo. Instituto de Biociências. Departamento de Genética e Biologia Evolutiva.

\section{Comissão Julgadora}

$\operatorname{Prof(a).\operatorname {Dr}(a).}$

$\operatorname{Prof(a).~Dr(a).~}$

Prof(a). Dr(a). Maria Cristina Arias 
Aos meus amados pais, à minha irmã, à minha querida namorada a todos os meus familiares, à todos os meus amigos, e a Deus dedico 


\section{.... Mais uma vez...}

Mas é claro que o sol vai voltar amanhã,

Mais uma vez eu sei

Escuridão já ví pior de endoidecer gente sã

Espera que o soljá vem.

Tem gente que está do mesmo lado que você

Mas devería estar do lado de lá

Tem gente que machuca os outros

Tem gente que não sabe amar

Tem gente enganando a gente

Veja a nossa vida como está

Mas eu sei que um dia a gente aprende

Se você quíser alguém em quem confiar

Confie em si mesmo

Quem acredita sempre alcança!

Mas é claro que o sol vai voltar amanhã

Mais uma vez eu sei

Escurídão já ví pior de endoidecer gente sã

Espera que o sol já vem.

Nunca deixe que the digam que não vale a pena

Acreditar no sonho que se tem

Ou que seus planos nunca vão dar certo

Ou que você nunca vai ser alguém

Tem gente que machuca os outros

Tem gente que não sabe amar

$\mathcal{M}$ as eu sei que um dia a gente aprende

Se você quíser alguém em quem confiar

Confie em si mesmo

Quem acredita sempre alcança!

Renato Russo

Tudo o que um sonho precisa para ser realizado, é alguém que acredite que ele possa ser realizado". 


\section{Agradecimentos}

Em primeiro lugar agradeço a Deus por ter me dado a vida, me sustentado até o presente momento e ter me dado força e sabedoria para ingressar na pós-graduação e realizar (e finalizar!) este trabalho.

Aos meus pais que sempre me incentivaram e encorajaram em todas as decisões que tomei. Por me guiarem nas horas difíceis, por confiarem em mim e sempre estarem ao meu lado quando precisei.

À minha namorada, Thaiomara, que de todas as formas e em todos os momentos possíveis, sejam eles alegres ou tristes, fáceis ou difíceis, sempre esteve ao meu lado e por ter me acompanhado durante todos estes anos, me encorajando nas horas que tive medo.

À toda minha família que sempre acreditou em mim.

Aos amigos do laboratório, Leandro (Jusé), Gustavo (Tavinho), Elaine, Alisson, Alayne e Susy pelo incentivo e aprendizagem que tive e pelos bons momentos que tivemos no laboratório.

Ao Flavio e à Rute por sempre me incentivar a fazer mestrado, me apoiar em São Paulo e também por sempre me encorajar e acreditar em mim, mesmo quando eu próprio não acreditava.

À minha orientadora, sem a qual eu não seria possível conquistar mais esta etapa de minha vida, pelos incansáveis ensinamentos que ela prestou a mim e pela paciência. 
À todos os que me forneceram amostras para que eu pudesse realizar este estudo.

À Dra. Favízia Freitas de Oliveira pela identificação dos espécimes deste estudo.

À toda equipe do CBMEG-UNICAMP, em especial à Profa. Dra. Anete Pereira de Souza, pela oportunidade de fazer o curso de construção de bibliotecas genômicas enriquecidas em microssatélites, o qual foi muito útil para a realização deste trabalho.

Ao Departamento de Genética e Biologia Evolutiva pela possibilidade de realizar o projeto.

Ao Projeto BIOTA-FAPESP pelo financiamento do projeto.

À CAPES pela bolsa concedida. 
1. INTRODUCÃ

1.1 As abelhas sem ferrão (tribo Meliponini) .............................................. 2

1.2 A espécie Frieseomelitta varia (Lepeletier 1836) ......................................... 3

1.3 Estudos populacionais e evolutivos em abelhas ….................................. 7

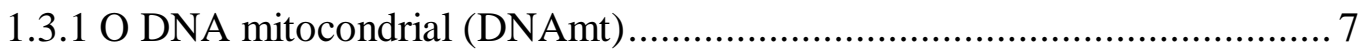

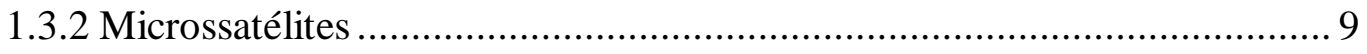

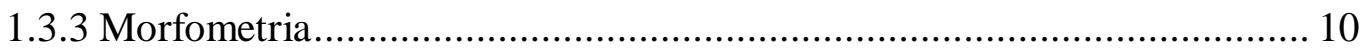

1.4 Pequenas populações versus variabilidade genética ................................ 12

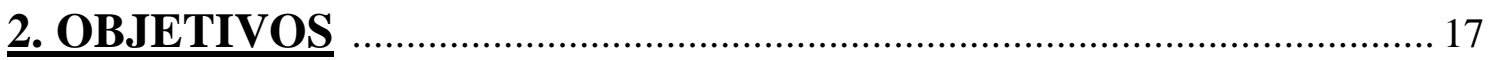

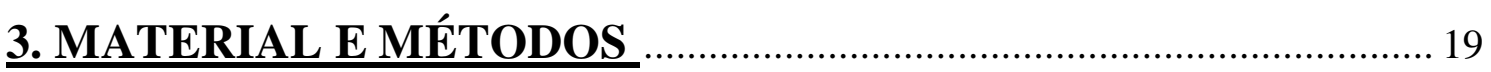

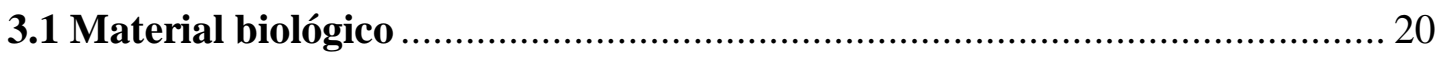

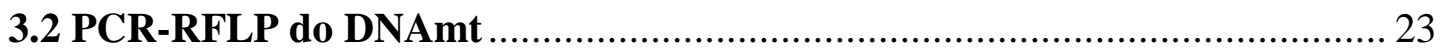

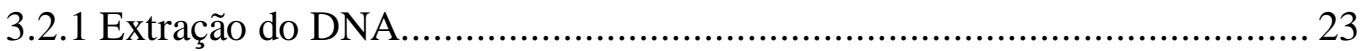

3.2.2 Amplificação de regiões do genoma mitocondrial via PCR .................... 24

3.2.3 Digestão dos produtos de PCR com enzimas de restrição ....................... 26

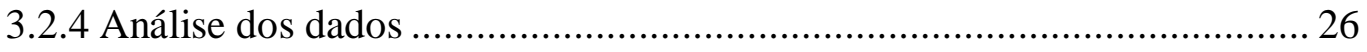

3.3 Sequenciamento de um trecho do gene Citocromo Oxidase I (COI) ..............2 28

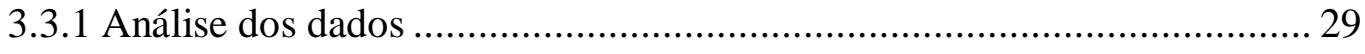

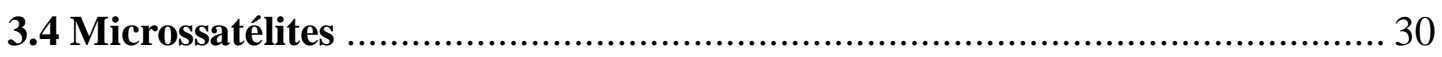

3.4.1 Construção da biblioteca enriquecida em microssatélites para

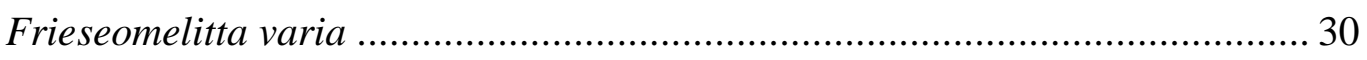

3.4.1.1 Extração de DNA total e Digestão com $R s a \mathrm{I}$................................ 30

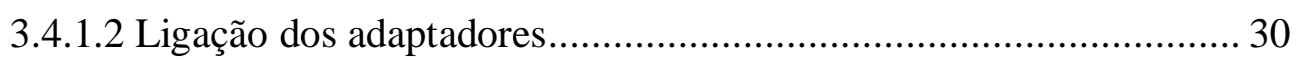

3.4.1.3 Pré-amplificação via PCR ....................................................... 31

3.4.1.4 Purificação do DNA ….......................................................... 31

3.4.1.5 Seleção dos fragmentos contendo microssatélites ......................... 32 
3.4.1.7 Clonagem dos produtos de PCR

3.4.1.8 Sequenciamento, visualização das sequências e identificação dos microssatélites 34

3.4.1.9 Desenho dos primers 35

3.4.1.10 Padronização das reações de PCR para a amplificação dos locos de microssatélites e resolução em géis de poliacrilamida 35

3.4.2 Padronização das condições de PCR e triagem populacional com os locos utilizados no estudo por análise de fragmentos em sequenciador automático.... 36

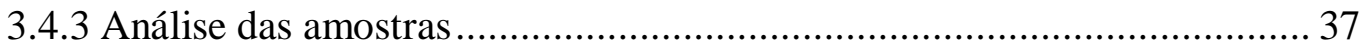

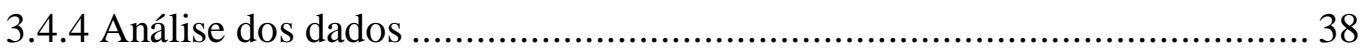

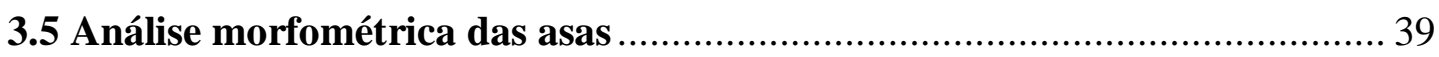

3.5.1 Análise dos dados ................................................................ 40

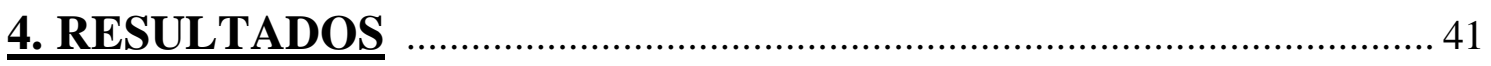

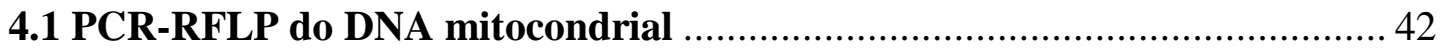

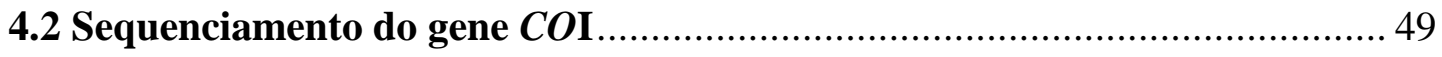

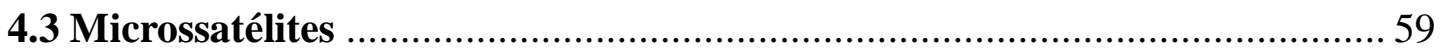

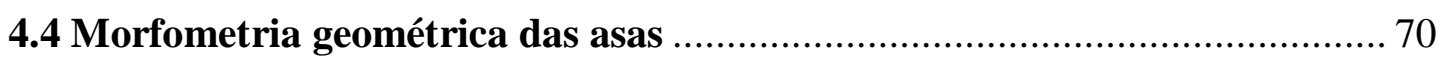

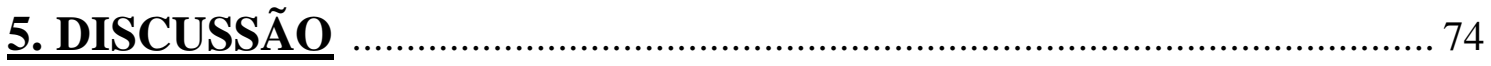

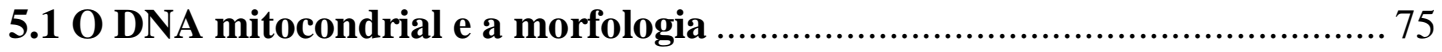

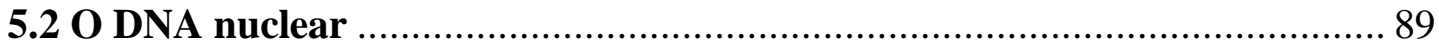

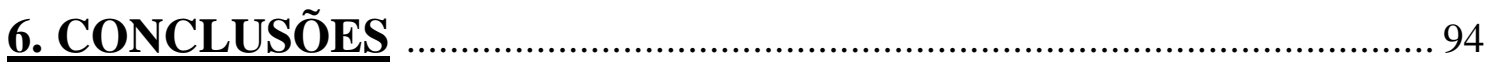

7. RESUMO

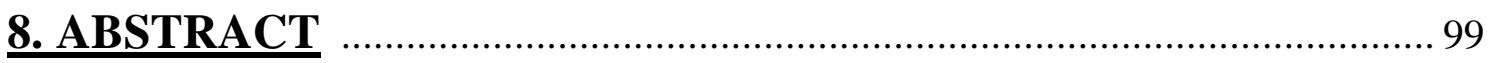

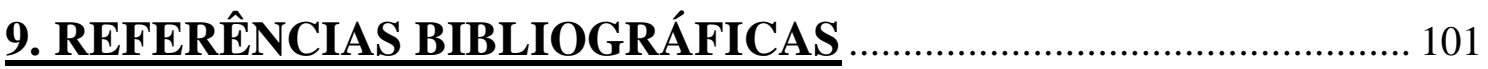

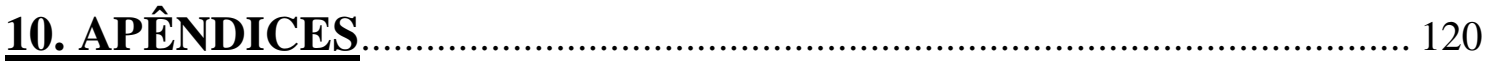


1. Introdução

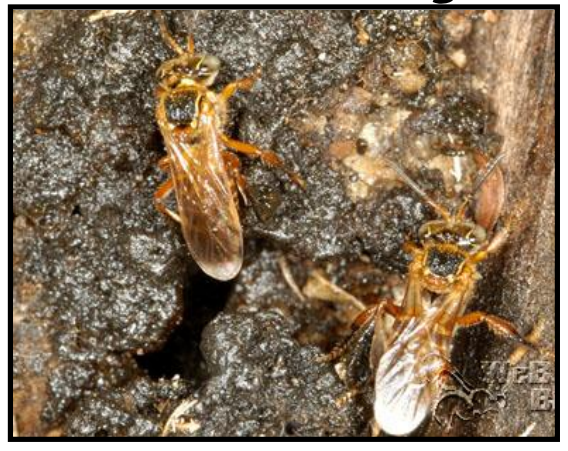




\subsection{As abelhas sem ferrão (tribo Meliponini)}

De acordo com Michener (2007), Apidae é uma das mais diversas famílias de abelhas existente, apresentando o maior número de tribos. A biologia de Apidae também é altamente diversificada, com comportamentos variando desde solitário a altamente social, espécies parasitas sociais, cleptoparasitas, e variação com relação ao substrato para construção do ninho como solo e ocos de árvores. Esta família é divida em três subfamílias: Xylocopinae, Nomadinae e Apinae. Esta última é a maior e mais diversificada, e na qual está contida a tribo Meliponini.

As abelhas da tribo Meliponini apresentam distribuição pantropical, ocupando principalmente as regiões neotropicais do planeta, embora sejam encontradas também em regiões subtropicais. São descritas mais de 400 espécies contidas em 50 gêneros, sendo que mais de 300 espécies pertencentes a 30 gêneros são encontradas nas Américas (Michener, 2007).

Os meliponíneos são caracterizados por possuírem o ferrão vestigial, e por isso, são comumente referidos como "abelhas sem ferrão". Outra característica que marca a tribo é o comportamento altamente social presente em todas as espécies (Michener, 2007). Em termos ecológicos, os meliponíneos apresentam um estreito relacionamento com as Angiospermas, sendo responsáveis por grande parte da polinização das plantas nativas, ainda, por serem abelhas poliléticas, visitam e coletam pólen de diversas espécies de plantas (Heard, 1999). No Brasil, os meliponíneos são responsáveis por cerca de 60 a $90 \%$ da polinização, conforme o ambiente onde estão inseridas (Kerr et al., 1996). Do ponto de vista econômico, as abelhas sem ferrão são importantes na 
produção de mel e outros produtos, e embora essa produção seja inferior à de Apis mellifera, a qualidade é tida como ótima. Portanto, esses produtos têm um alto valor agregado, sendo responsável por uma considerável fatia do faturamento do segmento apícola no mercado (Kerr, 1997). Por outro lado, existe o potencial incipiente das abelhas sem ferrão na polinização de culturas agrícolas comerciais (Malagodi-Braga e Kleinert, 2002).

Em função do desmatamento desenfreado que ocorre nos ambientes florestais, as abelhas sem ferrão estão sendo seriamente ameaçadas, pois dependem de ocos nas árvores para nidificarem e das flores para recursos alimentares (Kerr et al., 1996). Diversos outros fatores têm sido relacionados com a diminuição ou desaparecimento das populações de abelhas sem ferrão no Brasil. Dentre eles podemos citar a ação de meleiros que destroem completamente as colônias em busca do mel para a venda, a ação de serrarias e madeireiras que buscam árvores mais antigas, as quais geralmente possuem os locais mais adequados para nidificação das abelhas e o uso de inseticidas em culturas agrícolas ou mesmo nas cidades (para combate a vetores de doenças como a dengue), afetando assim as populações de regiões próximas (Kerr et al., 2001). Além disso, devemos também levar em consideração as atuais alterações climáticas que também vêm ameaçando não só as abelhas, mas muitas outras espécies animais e vegetais.

\subsection{A espécie Frieseomelitta varia (Lepeletier, 1836)}

O gênero Frieseomelitta (Ihering, 1912) apresenta distribuição geográfica que abrange os estados do Sudeste do Brasil até o México. O gênero é composto por 16 
espécies, das quais 10 estão presentes no Brasil: Frieseomelitta dispar, F. doederleini, $F$. flavicornis, $F$. francoi, $F$. languida, $F$. longipes, $F$. portoi, $F$. silvestrii, $F$. trichocerata, e por último temos a espécie alvo deste projeto, Frieseomelitta varia (Silveira et al., 2002).

A espécie Frieseomelitta varia (Figura 1), de acordo com Camargo e Pedro (2008), apresenta vasta distribuição geográfica, cobrindo os estados brasileiros da Bahia, Minas Gerais, São Paulo, Goiás, Tocantins, Mato Grosso, e alcançando até a região central da Bolívia (região de Santa Cruz) (Figura 2).

Sobre os locais de construção de ninhos, é citado na literatura que $F$. varia utiliza quase que exclusivamente pequenos ocos de árvores (Nogueira-Neto, 1997). Curtopassi-Laurino (2002) observou $F$. varia e $F$. silvestrii nidificando em ocos de árvores mortas, e troncos como os usados em mourões de cercas. Além disso, esse gênero utiliza resina na construção dos ninhos (Nogueira-Neto, 1997).

Em relação à estrutura do ninho, a $F$. varia constrói uma entrada pequena e circular, pela qual apenas uma abelha passa por vez (Couvillon e Ratnieks, 2008). As células de cria são construídas em forma de cacho e o mel é depositado em potes ovais; já o pólen é depositado em tubos cilíndricos de três a quinze centímetros de altura (Kerr et al., 1996) (Figura 3).

As células reais de Frieseomelitta não são propositalmente construídas, no entanto, as rainhas são grandes e emergem de casulos reais. Isso é explicado pelo fato de às vezes uma larva romper a parede de uma célula de cria vizinha e consumir o alimento ali presente, tornando-se maior em tamanho e tecendo um casulo maior, dito real (Nogueira-Neto, 1997). Outra característica interessante do gênero Frieseomelitta é o fato das operárias não produzirem ovos tróficos como faz grande parte dos meliponíneos (Kerr et al., 1996). 

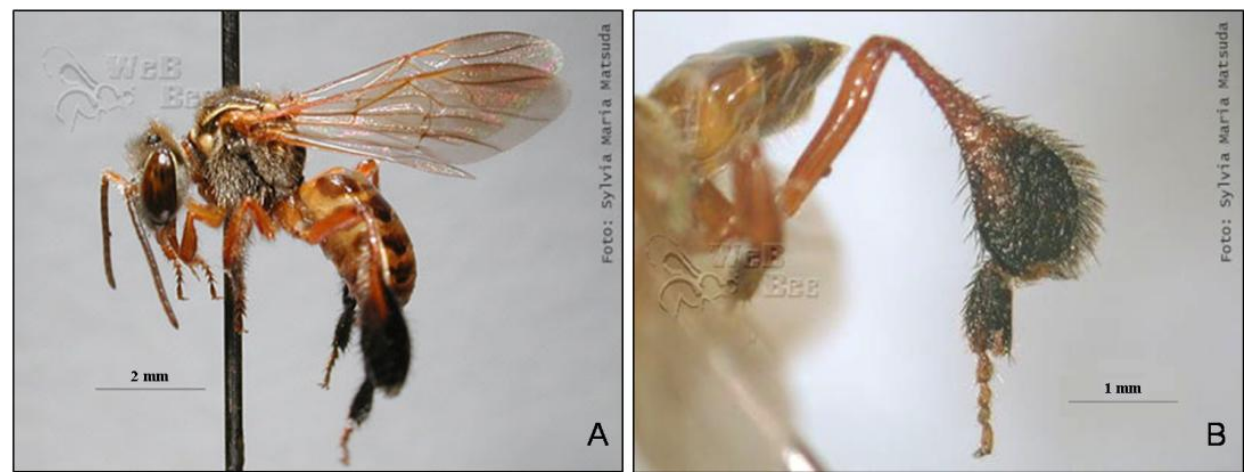

Figura 1: (A) Vista lateral de uma operária de Frieseomelitta varia. (B) Detalhe da espécie evidenciando a grande corbícula em forma de raquete. Fonte: http://www.webbee.org.br

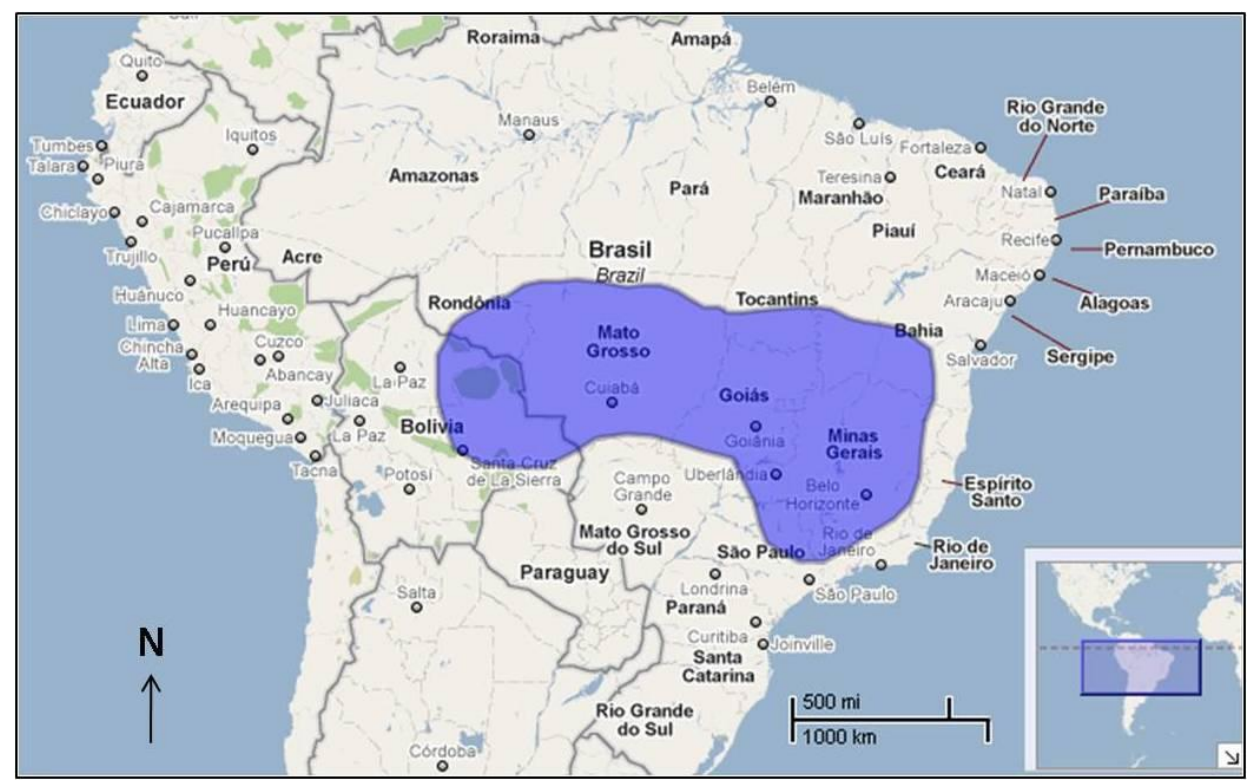

Figura 2: Distribuição geográfica de Frieseomelitta varia (área azul)

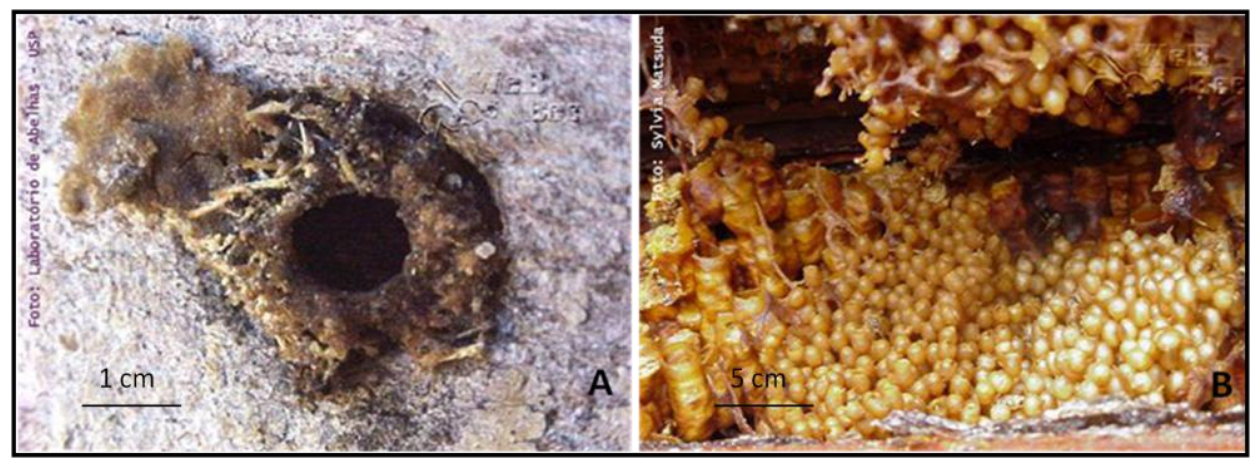

Figura 3: Detalhes da pequena entrada (A) e da estrutura interna do ninho (B) de Frieseomelitta varia mostrando os potes cilíndricos de pólen (à esquerda da foto B), as células de cria em forma de cacho (parte superior da foto B) e os potes ovais de mel. 
Há geralmente de uma a três guardas na entrada do ninho de Frieseomelitta varia. Estas são capazes de distinguir entre abelhas do próprio ninho e abelhas provenientes de outros ninhos por meio de sinais olfatórios (Couvillon e Ratnieks, 2008; Nunes et al., 2008). O padrão diário de trabalho das operárias de Frieseomelitta varia apresenta dois picos de entrada e saída no ninho: um por volta das 12:00 h, e outro por volta das 16:00 h, demonstrando preferência por temperaturas mais elevadas do dia (Mesquita et al., 2002; Teixeira et al., 2002 ).

O polietismo etário também está presente na espécie Frieseomelitta varia, ou seja, foi verificada uma relação entre a idade e a função desempenhada pelas operárias na colônia (Faustino et al., 2002). O polietismo é variável e depende das condições e necessidades da colônia em um determinado momento (Figueiredo et al., 2002). Foi observado que indivíduos que raspavam cerume das células do ninho apresentavam uma média de idade de 11 a 20 dias; abelhas que construíam células de cria apresentavam média de 51 a 60 dias de vida e abelhas que faziam limpeza apresentavam média de idade de 1 a 10 dias. O único trabalho realizado durante todo o período de vida dos indivíduos foi o trabalho com cera (Faustino et al., 2002; Figueiredo et al., 2002). De acordo com Figueiredo et al. (2002) Frieseomelitta varia apresenta uma longevidade de 6 a 61 dias, o que é pouco se comparado com Frieseomelitta silvestrii que vive de 7 a 155 dias.

Baptistella et al. (2007a) destacaram que essa espécie tem o hábito de construir os ninhos de forma agregada em áreas com alta densidade de árvores, buscando uma melhor fonte de recursos. Estes autores ressaltaram ainda a flexibilidade desta espécie na colonização de novas áreas, já que grande parte dos ninhos por eles estudados (84\%) se encontrava em cavidades pré-existentes de postes da rede elétrica. 


\subsection{Estudos populacionais e evolutivos em abelhas}

Tradicionalmente, a sistemática, evolução e a biologia geral de abelhas, principalmente dos Meliponini, têm sido estudadas por meio de análises morfométricas e comportamentais (Camargo e Pedro, 1992). Em Apis, análises multivariadas de caracteres morfológicos em conjunto com características comportamentais e ecológicas permitiram a descrição das inúmeras subespécies e espécies distribuídas nos continentes do Velho Mundo (Ruttner, 1988). Porém, por sofrerem influência do ambiente e por serem controlados por vários genes, o emprego desses caracteres em estudos de variabilidade genética é questionável. Nesse contexto, os marcadores moleculares passaram a exercer importante papel no estudo da diversidade e evolução das abelhas. Dentre as ferramentas moleculares recentemente mais utilizadas em estudos populacionais, estão o RFLP (Restriction Fragment Length Polymorphism) e sequenciamento do DNA mitocondrial (DNAmt) e os microssatélites. No entanto, a maioria dos estudos ainda se restringe às abelhas do gênero Apis, mais especificamente à Apis mellifera, colocando esta espécie como uma das mais estudadas entre os insetos. Dentro da ordem Hymenoptera, Apis mellifera foi a primeira, e a única espécie a ter o genoma mitocondrial (Crozier e Crozier, 1993) e nuclear (HGSC, 2006) totalmente sequenciados. No entanto, recentemente Silvestre et al. (2008) realizaram o sequenciamento parcialmente completo de uma segunda espécie de abelha altamente eussocial, Melipona bicolor, pertencente à tribo Meliponini.

\subsubsection{O DNA mitocondrial (DNAmt)}


O DNAmt é uma molécula circular e apresenta um conteúdo gênico bastante conservado evolutivamente. Esse pequeno genoma (em média apresenta $16 \mathrm{~Kb}$ nos animais) (Moritz et al., 1987), possui dois genes codificadores para as subunidades ribossômicas ( $12 S$ e $16 S$ ); vinte e dois genes para os RNA transportadores (RNAt); três genes para as subunidades da enzima citocromo oxidase (COI, II e III); um para o citocromo B; dois para as subunidades da enzima ATPase (subunidades 6 e 8); e sete para as subunidades da enzima NADH desidrogenase. Nos invertebrados há também uma região rica em $\mathrm{A}+\mathrm{T}$, não codificadora, e tida como responsável pela origem de replicação e transcrição da molécula do DNAmt (Wolstenholme, 1992) (Figura 4). O tamanho dessa região é extremamente variável entre as espécies, apresentando às vezes polimorfismo de tamanho a nível intraespecífico (Moritz et al., 1987).

A análise desse genoma, ou de alguns de seus genes, tem sido extremamente informativa para estudos filogenéticos, populacionais e evolutivos, pois apresenta alta taxa de evolução em relação ao genoma nuclear, não sofre recombinação, é pequeno, de estrutura gênica simples (não possui sequências repetitivas, pseudogenes e introns) e apresenta herança materna (Brown, 1985; Harrison, 1989).

Devido a tais atributos o DNAmt tem sido utilizado em diversos estudos em abelhas (Lobo et al., 1989; Del Lama et al., 1990; Garnery et al., 1991; Sheppard et al., 1991; Garnery et al., 1992; Arias e Sheppard, 1996; Franck et al., 1998; Meixner et al., 2000; El-Niweiri; Moritz, 2008, entre outros). 


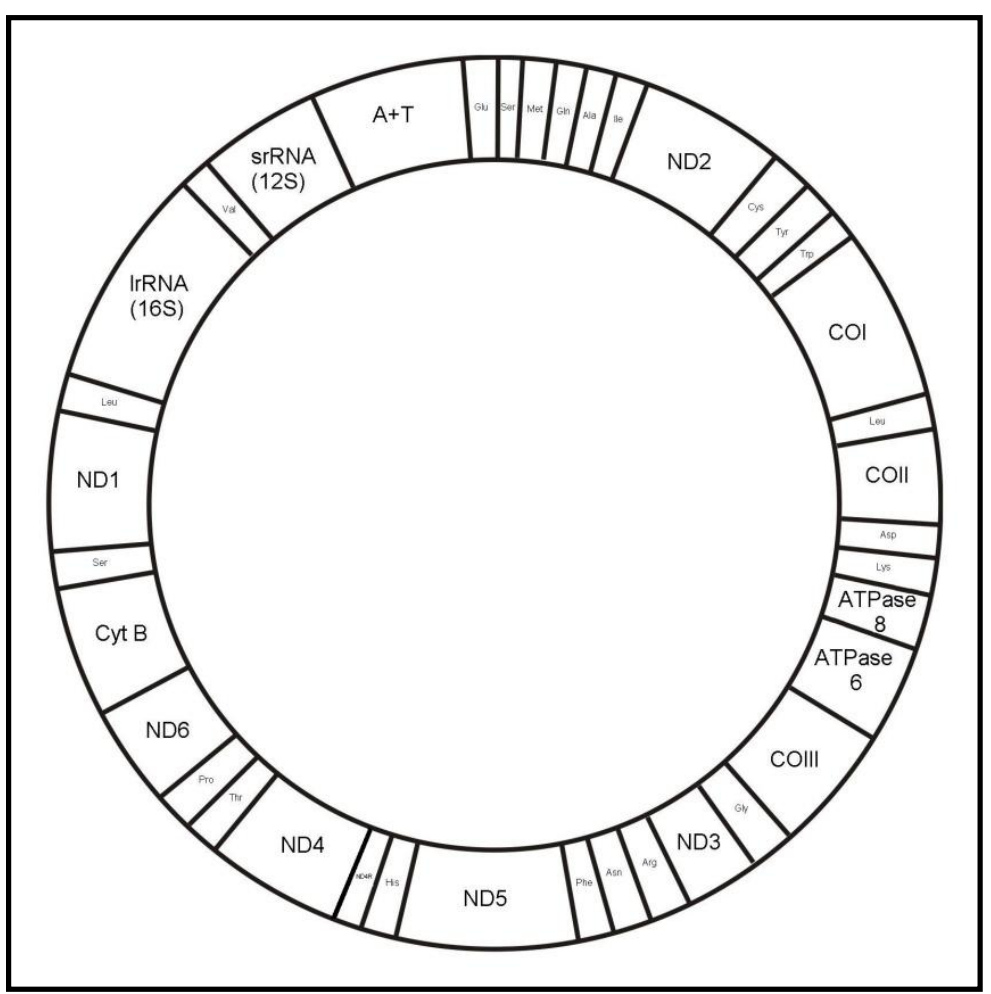

Figura 4: Representação esquemática do genoma mitocondrial de Apis mellifera mostrando seus genes. $12 \mathrm{~S}$ e 18S: Subunidades menor e maior do RNAr. ND1, ND2, ND3, ND4, ND5, ND6: Subunidades 1, 2, 3, 4, 5 e 6 da NADH desidrogenase. $C O$ I, $C O I I$ e $C O$ III: Subunidades I, II e III da citocromo c oxidase. ATPase 6 e ATPase 8: Subunidades 6 e 8 da ATP F0 sintase. Cyt B: Citocromo B. A+T: Origem de replicação e transcrição do DNAmt.

\subsubsection{Microssatélites}

Os microssatélites são definidos como regiões do genoma que contêm número variável de repetições (uma a cinco bases) em tandem (Hillis et al., 1996). Os microssatélites são classificados em quatro grupos: 1) perfeitos (ACACACACACAC); 2) imperfeitos (AGAGAGTGAGAG); 3) interrompidos (AGAGCCCAGAG) e 4) compostos (GAGAGAATATATAT). Tais regiões são amplificadas via PCR (Polymerase Chain Reaction) e são úteis em estudos genéticos por serem, caracteres mendelianos, codominantes, seletivamente neutros, altamente polimórficos e estarem amplamente distribuídos pelo genoma (Hillis et al., 1996; Strassmann et al., 1996). O 
polimorfismo entre os alelos reside na variação do número de cópias da repetição. Os microssatélites vêm sendo empregados em estudos de âmbito populacional e comportamental de diferentes espécies de abelhas (Estoup et al., 1993; Estoup et al., 1995; Widmer e Schmid-Hempel, 1999; Paxton et al., 1999b; Green et al., 2001; Francisco, 2002; Brito, 2005; Francisco et al., 2006; Francisco e Arias, 2010; Brito e Arias, 2010).

Em abelhas sem ferrão, locos de microssatélites foram isolados e caracterizados para oito espécies: Melipona bicolor (Peters et al., 1998), Scaptotrigona postica (Paxton et al., 1999), Trigona carbonaria (Green et al., 2001), Nannotrigona testaceicornis (Oliveira et al., 2009), Tetragonisca angustula (Brito et al., 2009), Melipona seminigra (Francini et al., 2009), Melipona rufiventris (Lopes et al., 2009a) e Melipona mondury (Lopes et al., 2009b).

\subsubsection{Morfometria}

Tradicionalmente, os estudos morfológicos em abelhas utilizavam uma série de medidas corporais como variáveis, baseando-se principalmente em análise univariada (onde se usava apenas um caractere por vez), tornando difícil a discriminação entre os grupos (Francoy, 2007). Somente a partir da década de 60, quando se começou a usar a morfometria multivariada (baseada em Análise de Componente Principal e Análises discriminantes) é que uma identificação mais robusta foi possível. A morfometria multivariada tem seu ápice em 1978 com a publicação de um trabalho de Ruttner, onde são descritas uma série de 40 medidas necessárias para a discriminação das subespécies de Apis mellifera (Ruttner et al., 1978). 
Surge então na década de 90 a Morfometria Geométrica (Bookstein, 1991) que se baseia em coordenadas cartesianas de pontos anatômicos (landmarks) marcados em estruturas homólogas, ao invés de medidas lineares (como as usadas na morfometria tradicional), fornecendo assim a posição relativa dos pontos (medida de deformação relativa). Esta metodologia tem a vantagem de possibilitar a reconstrução da forma estudada usando as posições relativas dos pontos marcados na mesma (Rohlf e Marcus, 1993). A morfometria geométrica também é baseada no que é denominado como relative warps. A base das relative warps é a análise de Distância de Procrustes, em que se faz a sobreposição de vários exemplares a uma dada configuração referência (principal warps). Esta referência pode ser qualquer exemplar da amostra ou a configuração média (consensus) da amostragem total (Francoy, 2007). Para cada landmark, um residual de Procruste é a diferença entre a posição dos landmarks dos exemplares e a posição do landmark homólogo do consensus (Rodrigues et al, 2003). A morfometria geométrica das asas tem sido usada com sucesso na discriminação de espécies de abelhas, baseando-se em pontos marcados manualmente nas junções das nervuras (Francoy et al., 2006; Mendes et al., 2007; Francoy, et al., 2008; Francisco et al., 2008).

$\mathrm{Na}$ tentativa de realizar estudos mais robustos e confiáveis vários trabalhos têm combinado marcadores moleculares e análises morfométricas para estabelecer a estrutura genética de populações de abelhas (Estoup et al., 1996; Widmer et al.,1998; Widmer e Shimid-Hempel, 1999; Hepburn et al., 2001; Kandemir et al., 2005; Kandemir et al., 2006; Francoy et al., 2007; Strange et al., 2008), sendo que há estudos em que as análises morfométricas revelaram alto grau de polimorfismo intraespecífico corroborando os dados moleculares (Quezada-Euán et al., 2006). 


\subsection{Pequenas populações versus variabilidade genética}

A ordem Hymenoptera é caracterizada por possuir o sistema genético Haplodiplóide. Neste, as fêmeas são geradas por ovos fertilizados sendo, portanto, diplóides (2n). Os ovos não fertilizados, haplóides (n), originam os machos. Em Hymenoptera o sistema de determinação sexual é governado pela composição alélica de um único loco, denominado Complementary Sex Determination (sl-CSD). (Beye et al., 2003; Hedrick et al., 2006; de Boer et al., 2007; de Boer et al., 2008). Os machos são hemizigotos enquanto que as fêmeas são heterozigotas para o loco CSD. No entanto, a homozigose deste loco em indivíduos diplóides, gera machos diplóides. Estes são extremamente prejudiciais para o ninho, pois além de serem estéreis, eles requerem a mesma quantidade de recursos que uma fêmea em desenvolvimento. Quando em grande número, os machos diplóides tendem a tornar a colônia fraca, ou até mesmo levá-la ao declínio, pois eles não realizam as funções que uma operária comum realizaria, como por exemplo, o forrageamento e a manutenção do ninho (Nogueira-Neto, 2002; Zayed e Packer, 2005; Kraus et al., 2007; Hein et al., 2009). Há na literatura alguns relatos onde os machos diplóides podem se reproduzir. Porém os indivíduos gerados por esses cruzamentos são inviáveis por serem triplóides (de Boer et al.,2007). Até o momento, apenas na espécie de vespa Euodynerus foraminatus o cruzamento de machos diplóides gera prole viável (Cowan e Stahlhut, 2004).

Diante deste cenário genético, Kerr e Vencovsky (1982) postularam a necessidade da manutenção de no mínimo 44 ninhos de uma mesma espécie de abelha para evitar o endocruzamento e a consequente perda da variabilidade genética da população, e em decorrência, a produção de machos diplóides. Esse número de ninhos seria suficiente para manter no mínimo seis alelos diferentes para o loco CSD, 
diminuindo a probabilidade de ocorrer homozigose neste loco e, portanto, a produção de machos diplóides. Por consequência, tal população teria maior sucesso de sobrevivência. Todavia, dados recentes demonstraram que o loco $C S D$ não está presente em Meliponini, estando restrito ao gênero Apis (Hasselmann et al., 2008). Apesar do loco CSD provavelmente não ser o determinante sexual neste grupo, por analogia, um mecanismo semelhante deve ser o responsável pelo sinal primário da diferenciação sexual em Meliponini. Deste modo, a possibilidade do loco CSD não existir nas abelhas sem ferrão não invalida a hipótese de Kerr e Vencovsky, já que os machos diplóides também são encontrados nessa tribo.

No entanto, há ainda na literatura contradição acerca do número mínimo de ninhos como postulado por Kerr e Vencovsky (1982). Nogueira-Neto (2002) tem mantido em meliponários poucos ninhos de espécies de abelhas que somente ocorrem em locais muito distantes, por exemplo, espécies nativas do nordeste brasileiro em meliponários na região sudeste. Esses ninhos foram por diversas vezes divididos, aumentando assim a sua população local no meliponário. Desde que ninhos novos não têm sido introduzidos na área de criação, a situação que temos retrata endogamia, o que diminuiria a variabilidade genética da população, que por sua vez levaria à produção de machos diplóides. Estudo recente demonstrou a existência de os machos diplóides com baixa frequência na maioria das colônias do meliponário do Dr. Paulo Nogueira Neto (Alves, 2010). Entretanto, Nogueira-Neto (2002) afirma ser necessária mais que uma simples condição de homozigose no loco da determinação sexual para a formação de machos diplóides. Em sua opinião, é necessária uma condição de associação entre estresse do ninho, baixa disponibilidade de recursos e baixa condição nutricional do ovo, juntamente com os fatores genéticos atuando para que sejam desenvolvidos os machos diplóides. 
Apesar de Nogueira-Neto (2002) sugerir que o aparecimento de machos diplóides não depende estritamente de um número mínimo de colônias por área, sabe-se que as pequenas populações são caracterizadas por sofrerem acelerado processo de perda de variabilidade genética devido ao endocruzamento a que estas estão sujeitas. Teoricamente, sabe-se que na condição de endocruzamento há a perda de metade da heterozigose por geração, sendo que ao passo de várias gerações esse valor tende a zero. Nesse caso, os genótipos homozigotos dominantes ou recessivos são fixados (Wright, 1969). A condição de endocruzamento conduz então a população a um menor tamanho efetivo, e por consequência, a um menor potencial de evolução. $\mathrm{O}$ endocruzamento tem sido relacionado com diversos componentes do fitness tais como menor fecundidade, maior esterilidade, maior mortalidade juvenil, desenvolvimento mais lento e maior susceptibilidade a estresses ambientais (Newman e Pilson, 1997; Randi et al., 2000; Bijlsma et al., 2000; Frankham et al., 2004). De fato, em pequenas populações isoladas o endocruzamento passa a ser inevitável já que com o passar do tempo todos os indivíduos se tornam relacionados.

Outro fenômeno que afeta as populações é a deriva genética. Esta é definida como a flutuação natural e aleatória das frequências alélicas das populações entre as gerações. A deriva genética ocorre devido a uma amostragem ao acaso dos gametas formadores das gerações (Frankham et al., 2004), sendo assim, apenas uma pequena fração dos alelos é efetivamente passada para a geração seguinte. Com este processo, alelos que se encontravam em uma dada frequência na população não necessariamente manterão a mesma frequência na geração seguinte, de modo que ao observar as frequências alélicas entre várias gerações subsequentes, verifica-se uma flutuação. A deriva genética pode levar à rápida fixação ou mesmo à eliminação de alelos, principalmente quando eles são raros, atuando de forma mais drástica em pequenas 
populações por gerar rápida diferenciação entre as mesmas e tendo uma maior chance de fixação de alelos deletérios que se mantêm em baixa freqüência (Lynch e Gabriel, 1990; Ellstrand e Elam, 1993; Frankham et al., 2004). O impacto negativo do pequeno tamanho populacional ocorre em todas as gerações, porém as maiores perdas vêm com o decorrer do tempo. Desta forma, espécies que experienciam prolongados períodos com tamanho populacional reduzido acumulam um maior prejuízo (Frankham et al., 2004).

A crescente fragmentação dos habitats tem contribuído drasticamente para o isolamento entre populações. Espécies que apresentam baixa capacidade de dispersão, ou grande dependência do habitat, ficam confinadas, levando à interrupção do fluxo gênico e acentuando os efeitos negativos da deriva genética (Beebee e Rowe, 2004).

Análises genéticas (marcadores de herança materna e biparental) combinadas com morfométricas em espécies de abelhas mantidas em condições de endocruzamento, sejam oriundas de fragmentos isolados de florestas ou de pequenas populações mantidas sob manejo, ainda não foram realizadas. Ainda, o fato de análises combinadas de RFLP do DNAmt e microssatélites terem demonstrado sucesso em vários estudos em nosso laboratório, nos deixou otimistas em aplicar as mesmas metodologias em combinação com análises morfométricas para Frieseomelitta varia. Portanto, no presente estudo pretendemos empregar técnicas moleculares e morfométricas no intuito da compreensão da estrutura populacional de uma pequena população de Frieseomelitta varia naturalmente distribuída pela área do campus da Universidade de São Paulo (USP) em Ribeirão Preto-SP. Essa população tem a peculiaridade de manter-se restrita à área do campus, não havendo sido encontrada uma densidade considerável de ninhos no entorno. Atualmente o campus da USP em Ribeirão Preto é uma área bastante arborizada e rodeada por áreas urbanas e por culturas de cana de açúcar e parece servir como uma área de refúgio, pois ali é encontrada uma grande diversidade de espécies de 
Meliponini (Freitas, 2001). Para a comparação da variabilidade genética da população do campus foram também obtidos dados de amostras coletadas ao longo da distribuição geográfica dessa espécie. Esse estudo se inseriu dentro de um projeto maior (Projeto Biota - FAPESP), que objetivou o estudo, sob diferentes aspectos biológicos, de polinizadores com ênfase em Meliponini. 


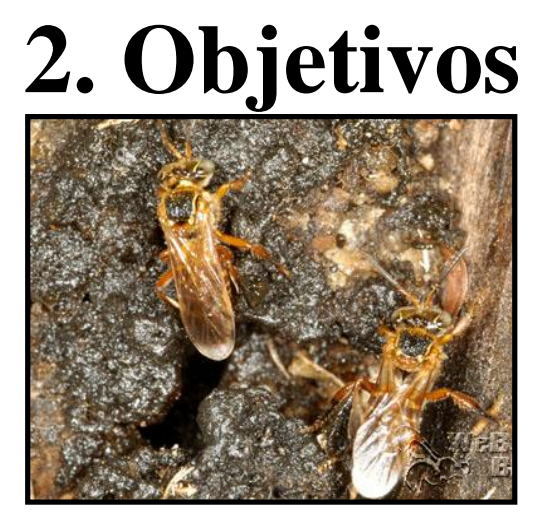


O objetivo central desse trabalho foi verificar a variabilidade genética de uma pequena população de Frieseomelitta varia, com posteriores inferências, sobre direção de fluxo gênico (via fêmea ou macho), e sobre a colonização da área do campus da USP-RP. Como objetivos específicos nós tivemos:

1. Analisar o polimorfismo do DNAmt através de enzimas de restrição e sequenciamento, em amostras de Frieseomelitta varia coletadas no campus da USP-RP e externas ao mesmo;

2. Determinar os haplótipos mitocondriais e suas relações genéticas;

3. Analisar a variabilidade do DNA nuclear das amostras de Frieseomelitta varia do campus da USP de Ribeirão Preto e das amostras externas por meio de microssatélites, utilizando primers isolados e caracterizados no laboratório para esta espécie;

4. Inferir o número de fêmeas (colônias) que deram origem à população atualmente residente no campus USP-RP, através dos diferentes haplótipos mitocondriais observados;

5. Analisar o polimorfismo do DNAmt através de enzimas de restrição, em amostras de Frieseomelitta trichocerata mantidas em um meliponário;

6. Analisar o padrão de morfometria geométrica das asas dos indivíduos coletados de três espécies: Frieseomelitta varia, $F$. trichocerata e $F$. doederleini.

Usar os resultados genéticos e morfológicos obtidos das amostras de $F$. varia, $F$. trichocerata e $F$. doederleini para uma possível validação da espécie $F$. trichocerata, já que esta é morfologicamente muito semelhante à $F$. varia. 


\section{Material e Métodos}

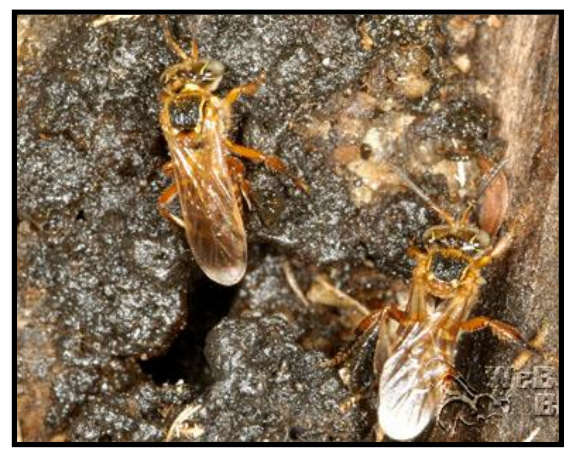




\subsection{Material biológico}

Foram coletados indivíduos de 33 ninhos de Frieseomelitta varia do Campus da USP de Ribeirão Preto (Figura 5), bem como de 36 ninhos ao longo da distribuição natural da espécie (Figura 6). Foram enviadas ao laboratório amostras de 30 ninhos de Frieseomelitta trichocerata provenientes de Espigão do Oeste, RO e de 3 ninhos de Frieseomelitta doederleini provenientes de Marechal Deodoro, AL. A Figura 6 ilustra os locais de origem dos ninhos amostrados.

Cabe esclarecer que as amostras de $F$. trichocerata e $F$. doederleini foram recebidas como sendo Frieseomelitta varia, porém foram identificadas corretamente pela Dra. Favízia Freitas de Oliveira, especialista na sistemática desse gênero. As amostras de F. trichocerata foram incluídas no estudo, pois constituem também uma pequena população. Estes ninhos vêm sendo mantidos sob condição de manejo há seis anos, de modo que 29 dos 30 ninhos amostrados foram gerados por divisões de apenas dois ninhos ancestrais nas dependências de um meliponário nas imediações de Espigão do Oeste-RO. O trigésimo ninho foi coletado em outro ponto da mesma cidade.

Para minimizar possíveis vieses nos resultados devido à distância entre os pontos de coleta, decidimos dividir as amostras coletadas em áreas externas ao campus da USP em 4 grupos baseados em proximidade geográfica. A Figura 7 ilustra a divisão das amostras externas nestes grupos. 


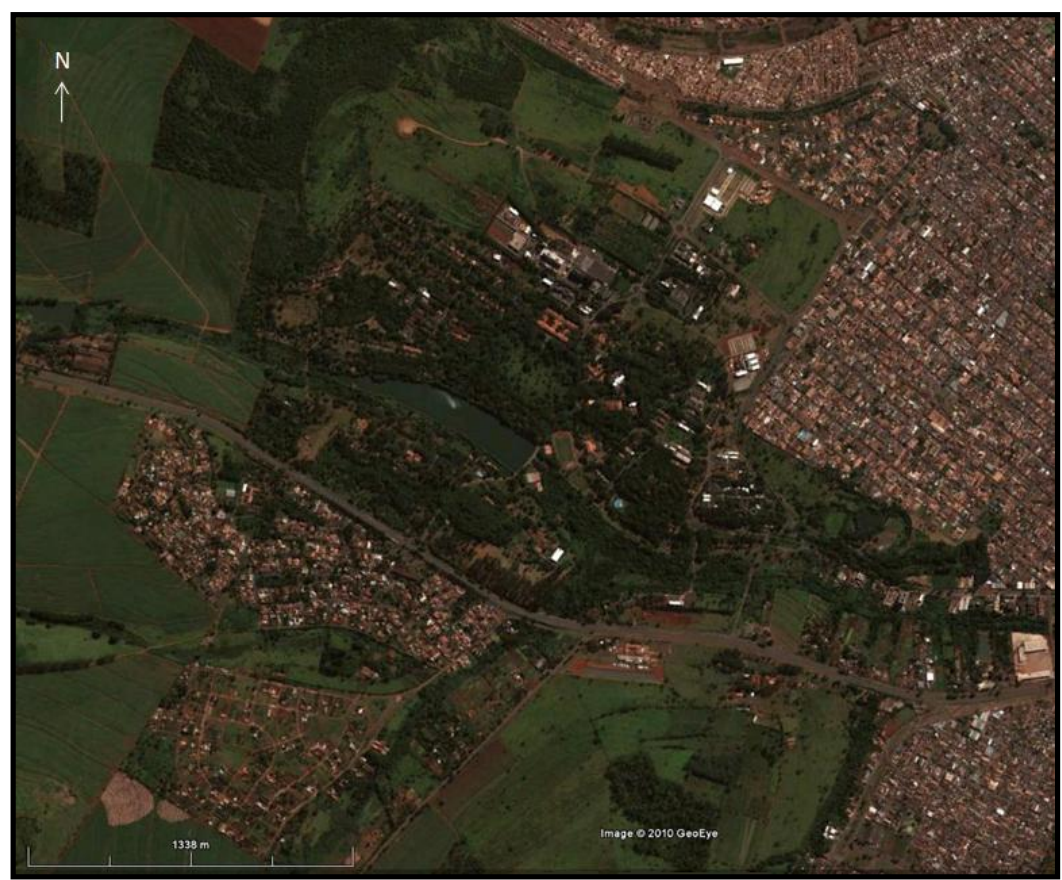

Figura 5: Imagem de satélite mostrando a área do campus da Universidade de São Paulo em Ribeirão Preto (área arborizada ao centro). Fonte: Google Earth.

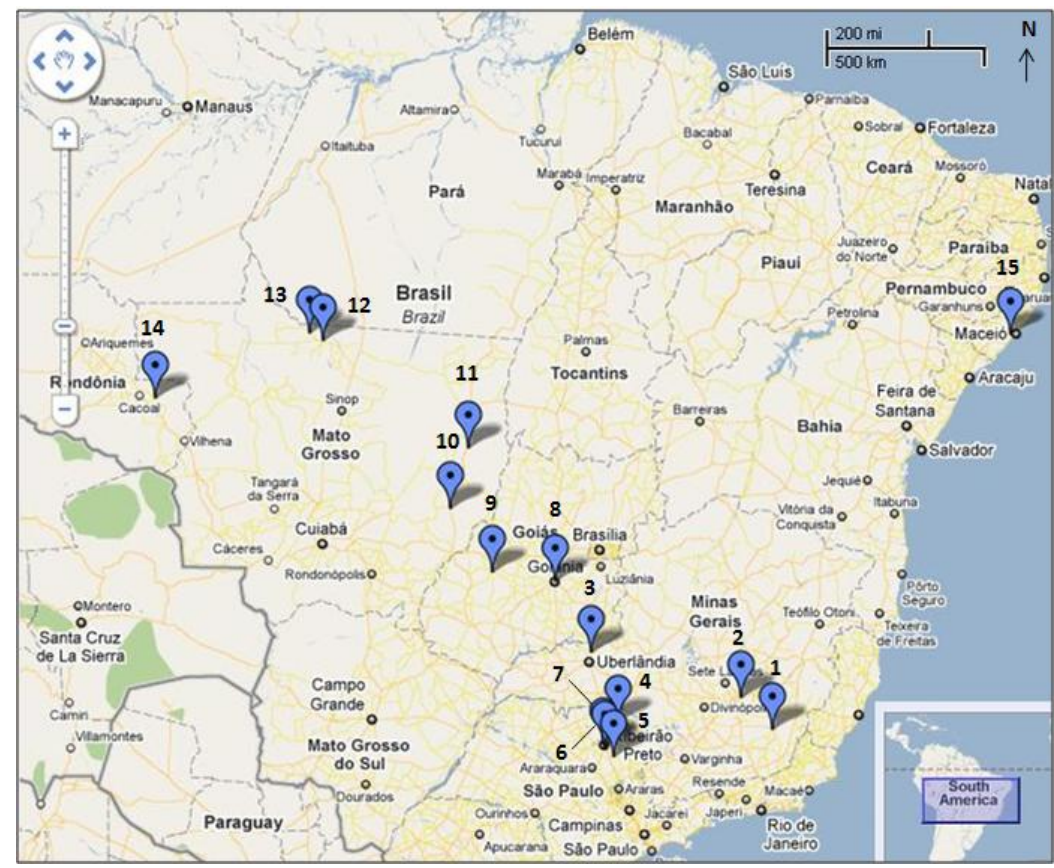

Figura 6: Mapa parcial do Brasil mostrando os pontos de coletas: 1) ViçosaMG (1 ninho); 2) Sabará-MG (5 ninhos); 3) Araguari-MG (1 ninho); 4) Franca-SP (8 ninhos); 5) São Simão-SP (2 ninhos); 6) Ribeirão Preto-SP (33 ninhos Campus USP e 2 de áreas externas); 7) Bonfim Paulista-SP (1 ninho); 8) Goiânia-GO (6 ninhos); 9) Iporá-GO (1 ninho); 10) Nova Xavantina-MT (4 ninhos); 11) Ribeirão Cascalheira -MT (3 ninhos); 12) Alta Floresta-MT (1 ninho); 13) Paranaíta-MT (1 ninho); 14) Espigão do Oeste-RO (30 ninhos $F$. trichocerata); 15) Marechal Deodoro-AL (3 ninhos F. doederleini). 


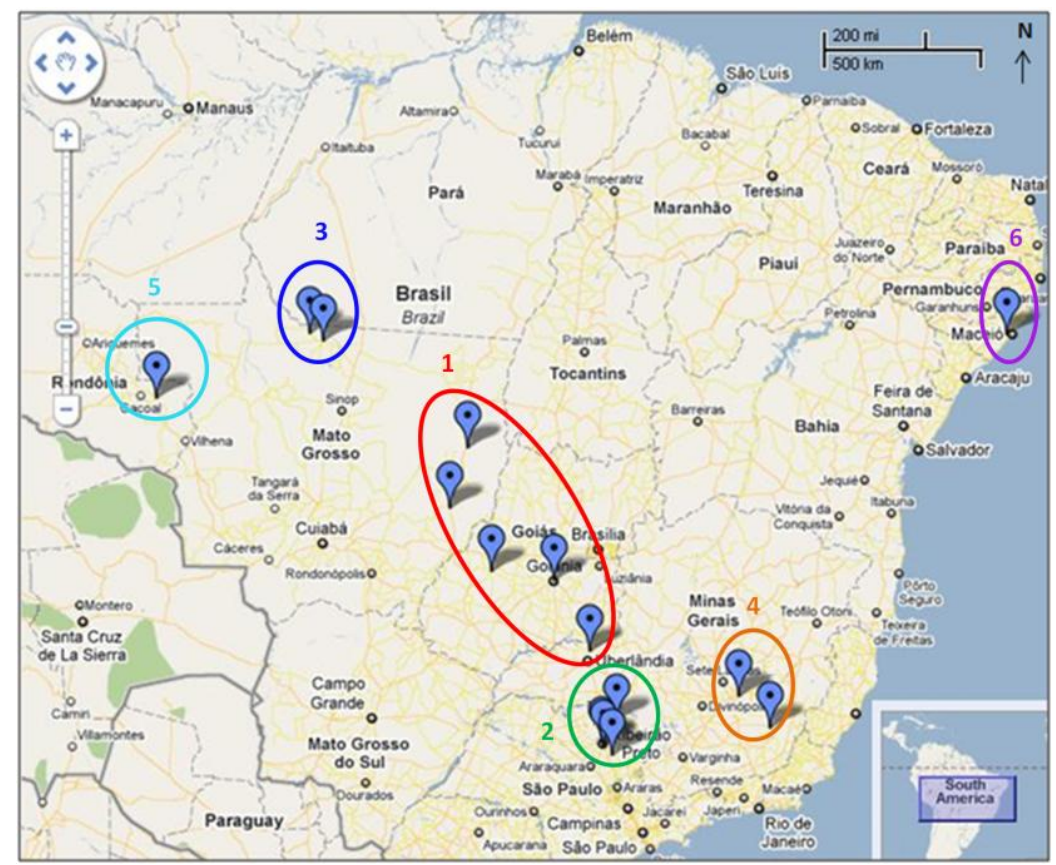

Figura 7: Mapa parcial do Brasil mostrando o agrupamento das amostras externas por proximidade geográfica. 1 Amostras de GO-MTMG (15 ninhos); 2 Amostras SP (13 ninhos); 3 Amostras do norte de MT (02 ninhos); 4 Amostras do sudeste de MG (06 ninhos); Amostras de $F$. trichocerata (30 ninhos); 6 Amostras de $F$. doederleini (03 ninhos) 


\subsection{PCR + RFLP do DNAmt}

Para a detecção de polimorfismos do DNA mitocondrial foi utilizada a técnica de PCR+RFLP em cinco regiões mitocondriais.

\subsubsection{Extração do DNA}

Para a extração de DNA total foi adotado o método "Mini-TNE" (Sheppard et al., 1994) com modificações. O tórax de um indivíduo foi macerado em $100 \mu \mathrm{l}$ da solução A [Tris-HCl 10mM (pH 8,0); SDS 10\%; NaCl 60mM; sucrose 14,61mM; EDTA $10 \mathrm{mM}(\mathrm{pH} 8,0)]$ acrescida de $0,5 \mu \mathrm{l}$ de proteinase-K $(20 \mathrm{mg} / \mathrm{ml})$ em um tubo de microcentrífuga. $\mathrm{O}$ macerado foi incubado a $56^{\circ} \mathrm{C}$ por 30 minutos e adicionou-se $100 \mu \mathrm{l}$ da solução B [Tris-HCl 300mM (pH 8,0); SDS 10\%; sucrose 14,61mM; EDTA 100mM (pH 8,0)]. Incubou-se no gelo por 10 minutos. Adicionou-se $200 \mu \mathrm{l}$ de fenol e misturouse bem por inversão. Mais uma vez incubou-se no gelo por 3 minutos. Centrifugou-se por 5 minutos a $14000 \mathrm{rpm}$ a $4{ }^{\circ} \mathrm{C}$. O próximo passo foi transferir o sobrenadante para um novo tubo de microcentrífuga de $1,5 \mathrm{ml}$. Adicionou-se $100 \mu \mathrm{l}$ de fenol e $100 \mu \mathrm{l}$ de clorofórmio/álcool isoamílico (24:1). Homogeneizou-se e incubou-se no gelo por 3 minutos. Seguiu-se centrifugação por 5 minutos a $14000 \mathrm{rpm}$ a $4{ }^{\circ} \mathrm{C}$. Tranferiu-se o sobrenadante para um novo tubo de microcentrífuga de $1,5 \mathrm{ml}$. Adicionou-se $200 \mu \mathrm{lde}$ clorofómio/álcool isoamílico (24:1). Homogeneizou-se brevemente. Novamente centrifugou-se por 5 minutos a $14000 \mathrm{rpm}$ a $4^{\circ} \mathrm{C}$. Transferiu-se o sobrenadante para um novo tubo de microcentrífuga de 1,5 ml. Adicionou-se $15 \mu \mathrm{l}$ de acetato de sódio $3 \mathrm{M}$ (pH $7,0)$ e $500 \mu 1$ de álcool $100 \%$. O próximo passo foi inverter os tubos cuidadosamente dez vezes. Incubou-se a $-20{ }^{\circ} \mathrm{C}$ overnight. Após isso, centrifugou-se por 20 minutos a $14000 \mathrm{rpm} \mathrm{a} 4{ }^{\circ} \mathrm{C}$. Descartou-se o sobrenadante fixando bem os tubos em um suporte e 
invertendo-os. Adicionou-se $30 \mu \mathrm{l}$ de etanol 70\%. Centrifugou-se por 10 minutos a $14000 \mathrm{rpm}$ a $4{ }^{\circ} \mathrm{C}$. Cuidadosamente removeu-se o sobrenadante novamente fixando os tubos na base do suporte e invertendo-os. Após isso, secou-se o pellet à vácuo por 5 minutos. O último passo foi ressuspender o pellet em $50 \mu \mathrm{l}$ de TE $1 \mathrm{X}$ (10mM Tris; $1 \mathrm{mM}$ EDTA).

\subsubsection{Amplificação de regiões do genoma mitocondrial via PCR}

As reações de PCR (Polymerase Chain Reaction) foram realizadas utilizandose DNA extraído pelo método "Mini-TNE". A solução de reação foi preparada com $5 \mu 1$ de tampão 10X da reação de PCR (Invitrogen), 3,0 $\mu \mathrm{l}$ de $\mathrm{MgCl}_{2} 50 \mathrm{mM}, 1 \mu \mathrm{l}$ de cada primer $20 \mu \mathrm{M}, 5 \mu \mathrm{l}$ de dNTPs $2 \mathrm{mM}$ cada, $0,5 \mu \mathrm{l}$ de Taq DNA polimerase $(5 \mathrm{U} / \mu \mathrm{l})$ (Invitrogen), 1,0 $\mu \mathrm{l}$ de DNA molde e água para atingir um volume final de $50 \mu \mathrm{l}$. Cada reação de PCR inicialmente foi submetida a uma desnaturação a $94^{\circ} \mathrm{C} / 5$ minutos, seguida de 35 ciclos de: [desnaturação a $94^{\circ} \mathrm{C} / 1$ minuto, hibridação a 1 minuto e 20 s a uma temperatura específica para cada par de primers (Tabela 1) e extensão a $64^{\circ} \mathrm{C} / 2$ minutos]. No final foi realizada uma extensão extra a $64^{\circ} \mathrm{C}$ durante 10 minutos.

Cinco regiões do DNAmt, compreendendo os genes [COII], [ATPase $6 e$ 8/COIII], [NDI/16S], [16S/I2S] e [COI], foram amplificadas em F. varia. Os primers utilizados foram os universais para o genoma mitocondrial de insetos (UBC Insect Mitochondrial DNA Primers Kit), ou derivados do genoma mitocondrial das abelhas Apis mellifera e Melipona bicolor (Tabela 1). Os produtos das reações de PCR foram separados por eletroforese em gel de agarose $0,8 \%$, corados em brometo de etídeo, visualizados em um transiluminador de luz UV e fotografados com uma câmera digital. A Figura 8 mostra as regiões amplificadas do genoma mitocondrial. 
Tabela 1: Primers e suas sequências, genes principais da região amplificada, temperatura de hibridação e tamanho do fragmento amplificado do DNAmt de $F$. varia.

\begin{tabular}{|c|c|c|c|c|}
\hline Nome & Sequência $\left(5^{\prime} \rightarrow 3^{\prime}\right)$ & $\begin{array}{c}\text { Genes } \\
\text { Principais }\end{array}$ & Temp. $\left({ }^{\circ} \mathrm{C}\right)$ & $\begin{array}{c}\text { Tamanho } \\
\text { estimado } \\
\text { (pb) }\end{array}$ \\
\hline $\begin{array}{l}\mathrm{COI}^{-I I F}{ }^{\mathrm{I}} \\
\mathrm{MtD}^{2} 8^{2}\end{array}$ & $\begin{array}{c}\text { TCTATACCACGACGTTATTC } \\
\text { CCACAAATTTCTGAACATTGACCA }\end{array}$ & COII & 42 & 950 \\
\hline $\begin{array}{l}\mathrm{MtD}_{1}{ }^{2} \\
\mathrm{MtD}_{2} 2^{2}\end{array}$ & $\begin{array}{l}\text { GAAATTTGTGGAGCAAATCATAG } \\
\text { TCAACAAAGTGTCAGTATCA }\end{array}$ & $\begin{array}{l}\text { ATPases } 8 \\
\text { e 6, COIII }\end{array}$ & 42 & 1900 \\
\hline $\begin{array}{l}\mathrm{Mel} 3^{3} \\
16 \mathrm{SF}^{1}\end{array}$ & $\begin{array}{c}\text { TAAAGTTAAAAAAGCAACTC } \\
\text { CACCTGTTTATCAAAAACATGTCC }\end{array}$ & $N D 1,16 S$ & 42 & 800 \\
\hline $\begin{array}{c}16 \mathrm{SR}^{1} \\
\mathrm{MtD}^{2} 6^{2}\end{array}$ & $\begin{array}{l}\text { CGTCGATTTGAACTCAAATCATG } \\
\text { AAACTAGGATTAGATACCCTATTAT }\end{array}$ & $16 S, 12 S$ & 42 & 1800 \\
\hline $\begin{array}{l}\mathrm{MtD}^{2} \\
\mathrm{MtD} 12^{2}\end{array}$ & $\begin{array}{c}\text { CAACATTTATTTTGATTTTTTGG } \\
\text { TCCAATGCACTAATCTGCCATATTA }\end{array}$ & COI & 42 & 980 \\
\hline
\end{tabular}

${ }^{1}$ : Hall e Smith ( 1991); ${ }^{2}$ : Simon et al. (1994); ${ }^{3}$ : Francisco et al. (2001)

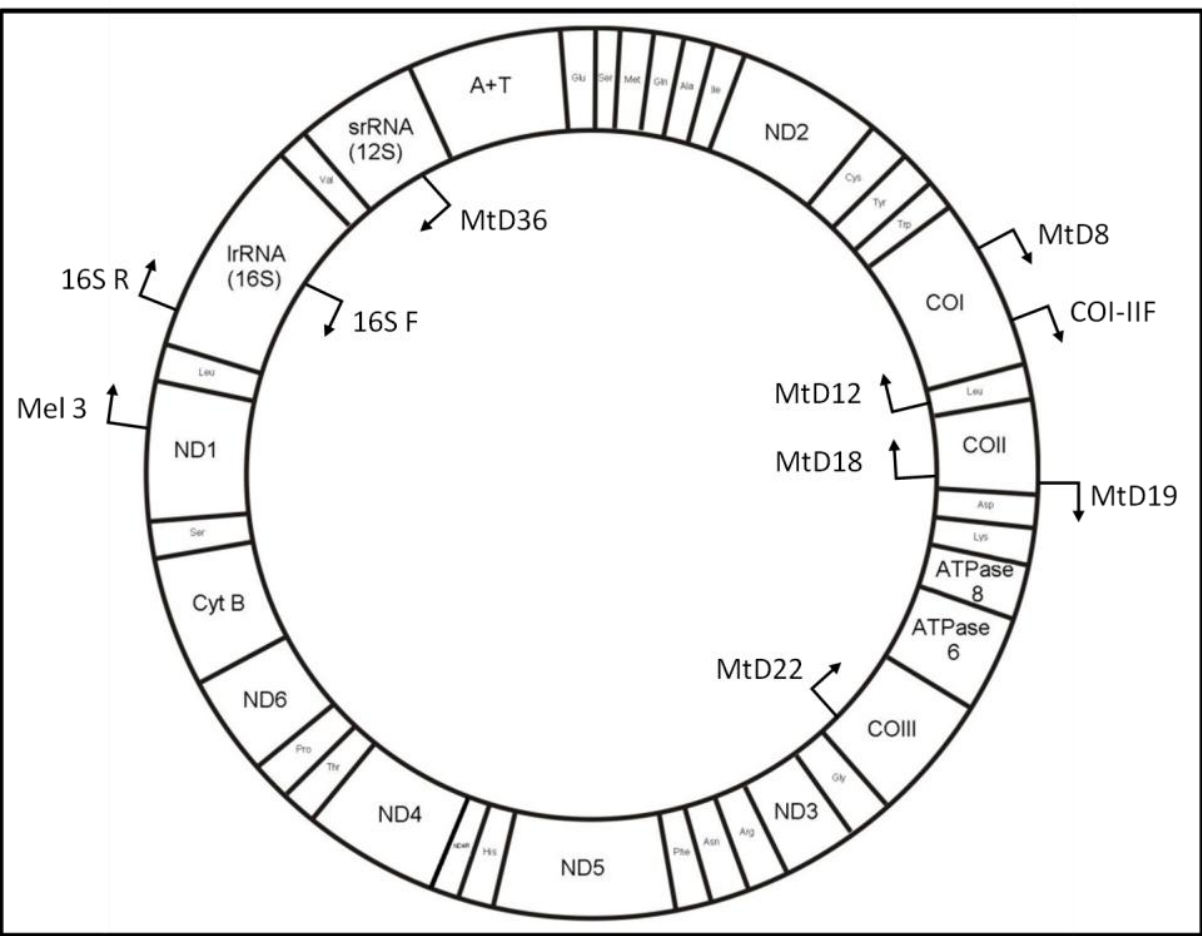

Figura 8: Representação esquemática do genoma mitocondrial de Apis mellifera mostrando a posição de ancoramento dos primers usados para a amplificação das 5 regiões do DNAmt de $F$. varia . 


\subsubsection{Digestão dos produtos de PCR com enzimas de restrição}

Para verificar a existência de sítios de restrição, os fragmentos de DNAmt amplificados via PCR, foram digeridos durante um período de no mínimo uma hora a $37^{\circ} \mathrm{C}$ com as 15 enzimas de restrição descritas na Tabela 2.

Tabela 2 - Enzimas de restrição utilizadas na digestão do DNAmt de $F$. varia e seus respectivos sítios de clivagem.

\begin{tabular}{c|c}
\hline ENZIMAS & SÍTIO DE RESTRIÇÃO \\
\hline$A s e$ I & AT / TAAT \\
\hline$B a m$ HI & G/GATCC \\
\hline$B c l$ I & T / GATCA \\
\hline$B g l$ II & A / GATCT \\
\hline$C l a$ I & AT / CGAT \\
\hline$D r a$ I & TTT / AAA \\
\hline$E c o$ R I & G / AATTC \\
\hline$E c o$ R V & GAT / ATC \\
\hline$H a e$ III & GG / CC \\
\hline$H i n f$ I & G / ANTC \\
\hline$M b o$ I & $/$ GATC \\
\hline$P s t$ I & CTGCA / G \\
\hline$R s a$ I & GT / AC \\
\hline$S s p$ I & AAT / ATT \\
\hline$X b a$ I & T / CTAGA
\end{tabular}

Os resultados das digestões foram analisados em géis de agarose $(0,8 \%$ ou $2 \%)$ corados com brometo de etídeo, ou em gel de poliacrilamida (5.6\% ou 9\%), corados com nitrato de prata para a visualização dos fragmentos. Posteriormente estes géis foram fotografados com câmera digital.

\subsubsection{Análise dos dados}

Cada padrão de restrição gerado pelas digestões enzimáticas foi designado por uma letra de modo que a combinação dos padrões de corte para uma determinada enzima para todas as regiões testadas foi designada por uma única letra maiúscula 
(Tabelas 29 e 30 - Apêndices). Deste modo, suponhamos que uma enzima tenha apresentado sítio de corte em duas regiões; na primeira região havia três padrões de corte distintos (padrões A, B e C), e na segunda havia apenas um padrão (padrão A). As 3 possíveis combinações entre esses 2 padrões de corte foram nomeadas por um única letra (Ex. AA = Haplótipo A; AB = Haplótipo B; AC = Haplótipo C). Essa metodologia foi aplicada para cada enzima sumarizando seus padrões de corte para as cinco regiões estudadas em conjunto. Os haplótipos compostos foram formados pela justaposição dessas letras (ex: CABABBACACAA).

Para os cálculos estatísticos foi usado o pacote de programas REAP (Restriction Enzyme Analysis Package) v.4.0 (MCElroy et al., 1992). Neste pacote estão inclusos diversos softwares, a exemplo do programa Generate que produziu uma matriz de presença e ausência de bandas a partir dos haplótipos compostos. A partir desta matriz, o programa D computou as distâncias genéticas (divergência de sequência de nucleotídeos) entre os haplótipos encontrados (d) (Nei e Tajima, 1981). O programa DA calculou o índice de diversidade haplotípica $(h)$ (Nei, 1987), os valores de diversidade nucleotídica dentro de cada população (p) e de divergência de sequência de nucleotídeos entre todos os pares de populações (d) (Nei e Tajima, 1981). O programa ARLEQUIM v.3.1 (Excoffier et al., 2005) foi usado para calcular o teste exato em conjunto com a cadeia de Markov para verificar a diferenciação entre as populações (Raymond e Rousset, 1995a; Goudet et al., 1996), bem como para calcular a estrutura populacional através da análise da variância molecular (AMOVA) (Excoffier et al., 1992). Para construir um fenograma baseado no método de Evolução Mínima a partir dos valores de $d$ foi usado o programa MEGA v.4.0 (Tamura et al., 2007). Para construir uma rede de relações entre os haplótipos foi usado o software NETWORK v. 4.5.1.0 (Polzin e Daneschmand, 2003). 


\subsection{Sequenciamento de um trecho do gene Citocromo}

\section{Oxidase I (COI)}

Um indivíduo de cada ninho foi utilizado para a amplificação da região do gene COI utilizando-se os primers listados na Tabela 3, seguindo as mesmas condições de amplificação das regiões mitocondriais descritas no item 3.2.2. Uma alíquota de $5 \mu$ do produto da amplificação foi previamente analisada em gel de agarose $0,8 . \%$.

Tabela 3: Primers, suas sequências e temperatura de hibridação, usados para a amplificação da porção do gene mitocondrial $C O I$.

\begin{tabular}{c|c|c|c}
\hline Nome & Sequência $\left(\mathbf{5}^{\prime} \rightarrow \mathbf{3}^{\prime}\right)$ & Temp. $\left({ }^{\mathbf{O}} \mathbf{C}\right)$ & Referência \\
\hline MtD6 & GGAGGATTTGGAAATTGATTAGTTCC & \multirow{2}{*}{42} & Simon et al., 1994 \\
\hline MtD9 & CCCGGTAAAATTAAAATATAAACTTC & & \\
\hline
\end{tabular}

Ao volume restante, $45 \mu \mathrm{l}$, adicionou-se $10 \mu \mathrm{l}$ de $\mathrm{NH}_{4} \mathrm{OAC} 7,5 \mathrm{M}$ e $100 \mu \mathrm{l}$ de etanol $100 \%$ à temperatura ambiente. Misturou-se bem e a precipitação ocorreu à temperatura ambiente por 5 minutos. O tubo foi centrifugado a $12000 \mathrm{rpm}$ por 5 minutos e o sobrenadante removido. Adicionou-se $100 \mu \mathrm{l}$ de etanol $70 \%$ à temperatura ambiente. Centrifugou-se por mais 5 minutos a $12000 \mathrm{rpm}$ e novamente removeu-se o sobrenadante. As amostras foram secas à vácuo por 5 minutos, e ressuspendidas em 10 $\mu l$ de TE $1 X$. O DNA foi quantificado em gel de agarose $0,8 \%$.

Para a reação de sequenciamento utilizou-se o conjunto de reagentes "Big Dye Terminator v.3.1" (Applied Biosystems). As concentrações de DNA molde e de primer seguiram as instruções do fabricante. Após a reação de Big Dye, as amostras foram 
precipitadas por 15 minutos no gelo com $25 \mu \mathrm{l}$ de uma solução composta por $55 \mu \mathrm{l}$ de glicogênio ( $1 \mathrm{mg} / \mathrm{ml}), 55 \mu \mathrm{l}$ de acetato de sódio $(7,5 \mathrm{M} \mathrm{pH} 7,0)$ e $1375 \mu$ l etanol 100\%. As amostras foram centrifugadas a $4000 \mathrm{rpm}$ por 30 minutos e o sobrenadante descartado. Adicionou-se ao tubo $50 \mu \mathrm{l}$ de etanol $70 \%$ gelado e centrifugou-se por mais 30 minutos a $4000 \mathrm{rpm}$. O sobrenadante foi retirado e as amostras foram secas em um termociclador a $95^{\circ} \mathrm{C}$ por 1 minuto. As reações foram analisadas em um sequenciador automático, modelo ABI-PRISM 3100 (Perkin Elmer), do Departamento de Química do IQ-USP. Foi sequenciada a fita forward de cada amostra.

\subsubsection{Análise dos dados}

As sequências foram visualizadas e editadas pelo software BIOEDIT v. 7.0 (Hall, 1999). Este software também foi usado para realizar a tradução em aminoácidos das sequências e assim verificar a possível presença de códons de parada nas proteínas. O alinhamento das sequências foi realizado com o auxílio do software MUSCLE v. 3.7 (Edgar, 2004). Para a determinação do número de haplótipos, diversidade haplotípica (h) e diversidade nucleotídica ( $\pi$ ) foi usado o software DnaSP v.5.0. (Librado e Rosas, 2009). Para verificar a estrutura populacional (AMOVA), calcular o teste exato de diferenciação populacional em conjunto com a cadeia de Markov foi usado o software ARLEQUIM v.3.1 (Excoffier et al., 2005). Para a construção de rede de haplótipos foi usado o programa NETWORK v. 4.5.1.0 (Polzin e Daneschmand, 2003). Foi construída uma árvore baseada em distância genética pelo método de Neighbor Joining com auxílio do programa MEGA v.4.0 (Tamura et al., 2007). 


\subsection{Microssatélites}

Para a análise dos microssatélites tentamos inicialmente a amplificação dos locos com primers heteroespecíficos. Porém, devido ao insucesso (poucos locos amplificaram e apresentaram baixo polimorifsmo), optamos pela estratégia de construção de bibliotecas enriquecidas em microssatélites específicos para $F$. varia. Para este fim, seguimos a metodologia descrita por Billote et al. (1999) com algumas modificações. Os detalhes seguem abaixo.

\subsubsection{Construção da biblioteca enriquecida em microssatélites para}

\section{Frieseomelitta varia:}

\subsubsection{Extração de DNA total e Digestão com $R s a I$ :}

A extração do DNA total de $F$. varia foi realizada seguindo o protocolo descrito anteriormente. Uma alíquota do DNA total foi digerida com a enzima Rsa I para gerar fragmentos de tamanhos adequados (200 a 900 pb). Para isso, em um tubo de microcentrífuga de $1,5 \mathrm{ml}$, adicionou-se $60 \mu \mathrm{l}$ de água MilliQ, $10 \mu \mathrm{l}$ de tampão 10X específico da enzima, $5 \mu l$ de enzima $(10 \mathrm{U} / \mu \mathrm{l})$ e $25 \mu \mathrm{l}$ de DNA na concentração de 250 ng/ $\mu$ l, totalizando $100 \mu \mathrm{l}$. Incubou-se a reação overnight a $37^{\circ} \mathrm{C}$. Os fragmentos gerados após digestão foram separados em gel de agarose, corados com brometo de etídeo e visualizados em um transiluminador UV.

\subsubsection{Ligação dos adaptadores:}

Após a digestão, procedeu-se com a ligação de adaptadores aos fragmentos. Para isso, adicionou-se $26 \mu l$ de água MilliQ, $10 \mu l$ de tampão 5X específico da enzima, 
$2 \mu 1$ de cada um dos adaptadores ( Rsa21: 5' TCTTGCTTACGCGTGGACTA 3' e Rsa25: 5' TAGTCCACGCGTAAGCAAGAGCACA 3') (10 $\mu \mathrm{M}$ cada), $4 \mu$ da enzima

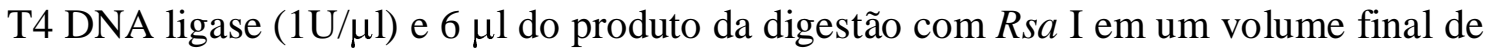
$50 \mu \mathrm{l}$. Ao final incubou-se no termociclador por duas horas a $20^{\circ} \mathrm{C}$.

\subsubsection{Pré-amplificação via PCR:}

Após a ligação dos adaptadores procedeu-se a amplificação via PCR dos fragmentos ligados para o enriquecimento da amostra. Para tanto, a reação foi montada em tubos de microcentrífuga de 0,2 ml adicionando-se 27, $5 \mu$ le água MilliQ, 2,5 $\mu 1$ de cada um dos dois tampões da reação de PCR (Fermentas), 1,5 $\mu \mathrm{l}$ de $\mathrm{MgCl}_{2}(50 \mathrm{mM})$, $4 \mu \mathrm{l}$ de dNTP (2 mM cada), $2 \mu \mathrm{l}$ do primer Rsa21 $(10 \mu \mathrm{M}), 5 \mu \mathrm{l}$ de Taq DNA polimerase (concentração final de $3 \mathrm{U}$ ) e $5 \mu \mathrm{l}$ do produto da ligação dos adaptadores. Posteriormente essa reação foi submetida a uma temperatura de $95^{\circ} \mathrm{C}$ por 4 minutos e 20 ciclos de: [94 ${ }^{\circ} \mathrm{C}$ por 30 segundos, $60{ }^{\circ} \mathrm{C}$ por 1 minuto e $72{ }^{\circ} \mathrm{C}$ por 1 minuto]. Ao final do ciclo uma extensão extra a $72^{\circ} \mathrm{C}$ por 8 minutos foi realizada.

Uma alíquota desta pré-amplificação foi visualizada em gel de agarose $0,8 \%$, corado com brometo de etídeo, visualizado em um transiluminador UV e fotografado com o auxílio de uma câmera digital.

\subsubsection{Purificação do DNA:}

Em seguida foi realizada uma etapa de purificação do DNA resultante da préamplificação. Para este objetivo foi usado um conjunto de reagentes comercial de purificação (DNA Clean-up - PROMEGA), seguindo o protocolo e as especificações do fabricante. O objetivo desta etapa foi preparar o DNA para a posterior seleção dos fragmentos de interesse. 


\subsubsection{Seleção dos fragmentos contendo microssatélites:}

Preparo das beads magnéticas com estreptavidina: Foram ressuspendidos $600 \mu \mathrm{l}$ de beads (Streptavidin magnesphere-Paramagnetic particles - Promega) por agitação, seguida de exposição a uma coluna magnética por 30 segundos. Aspirou-se o sobrenadante. Adicionou-se $300 \mu \mathrm{l}$ de SSC $0,5 \mathrm{X}$, ressuspendeu-se por agitação, magnetizou-se por 30 segundos e descartou-se o sobrenadante. Esse processo de lavagem das beads foi repetido por mais três vezes e ao final elas foram ressuspendidas em $100 \mu 1$ de SSC 0,5X.

Preparo do DNA purificado: Adicionou-se $400 \mu \mathrm{l}$ de água MilliQ a $100 \mu \mathrm{l}$ de DNA purificado. Incubou-se por 15 minutos a $95{ }^{\circ} \mathrm{C}$ para a desnaturação. Adicionou-se $13 \mu \mathrm{l}$ de SSC $20 \mathrm{X}$ e $3 \mu \mathrm{l}$ de cada sonda marcada com biotina $\left[(\mathrm{CT})_{8},(\mathrm{GT})_{8},(\mathrm{AG})_{8}\right.$ e $(\mathrm{AGA})_{5}$, todas a $\left.50 \mu \mathrm{M}\right]$. Incubou-se à temperatura ambiente por 20 minutos agitandose o tubo a cada 2 minutos para que as sondas se hibridassem a regiões complementares. Adicionou-se a esta solução os $100 \mu \mathrm{l}$ de beads previamente lavadas. Agitou-se levemente por 10 minutos à temperatura ambiente. Nesse passo as beads contendo estreptavidina se ligaram à biotina das sondas. Magnetizou-se por 30 segundos, aspirouse o sobrenadante e ressuspendeu-se em $300 \mu \mathrm{l}$ de SSC 0,1X. Esta etapa foi repetida três vezes e ao final ressuspendeu-se em $100 \mu$ de água MilliQ e magnetizou-se por mais 30 segundos. Reservou-se então o sobrenadante (supostamente contendo fragmentos com repetições) em um novo tubo de microcentrífuga e procedeu-se mais uma lavagem das beads com $150 \mu \mathrm{l}$ de água MilliQ para garantir que todos os fragmentos selecionados fossem recuperados. Juntou-se os dois sobrenadantes recuperados $(100 \mu 1+150 \mu \mathrm{l})$.

\subsubsection{Amplificação dos fragmentos selecionados:}


Após a seleção dos fragmentos de interesse, procedeu-se com a amplificação dos mesmos por PCR. As reações foram realizadas em um volume final de $100 \mu \mathrm{l}$. Foram adicionados em um tubo de microcentrífuga 51,5 $\mu$ l de água MilliQ, $10 \mu \mathrm{l}$ de tampão de PCR 10X, $6 \mu l$ de $\mathrm{MgCl}_{2} 25$ mM, $8 \mu \mathrm{l}$ de dNTP 2,5 mM cada, $4 \mu \mathrm{l}$ de primer Rsa21 $10 \mu \mathrm{M}, 0,5 \mu \mathrm{l}$ de Taq Polimerase (3 U) (Invitrogen) e $20 \mu \mathrm{l}$ dos fragmentos selecionados como DNA molde da reação. Posteriormente essa reação foi submetida a uma temperatura de $95{ }^{\circ} \mathrm{C}$ por 1 minuto e 25 ciclos de: $\left[94^{\circ} \mathrm{C}\right.$ por 40 segundos, $60{ }^{\circ} \mathrm{C}$ por 1 minuto e $72{ }^{\circ} \mathrm{C}$ por 5 minutos]. Ao final do ciclo uma extensão extra a $72{ }^{\circ} \mathrm{C}$ por 8 minutos foi realizada. O resultado desta amplificação foi analisado em um gel de agarose $0,8 \%$, corado com brometo de etídeo e visualizado em um transiluminador UV.

\subsubsection{Clonagem dos produtos de PCR:}

Um volume de $40 \mu 1$ do produto de PCR foi precipitado com $10 \mu 1$ de acetato de amônia 7,5 M e $100 \mu \mathrm{l}$ de etanol absoluto, por 5 minutos à temperatura ambiente. Em seguida, o microtubo foi centrifugado a $12000 \mathrm{rpm}$ por 5 minutos à temperatura ambiente. Descartou-se o sobrenadante. O precipitado foi lavado com $100 \mu \mathrm{l}$ de etanol $70 \%$ e em seguida centrifugado a $12000 \mathrm{rpm}$ por 5 minutos. Por fim, o precipitado foi seco à vácuo e ressuspendido em $10 \mu \mathrm{l}$ de $\mathrm{TE} 1 \mathrm{X}$, dos quais $3 \mu \mathrm{l}$ foram submetidos à eletroforese em gel de agarose $0,8 \%$ para uma quantificação visual antes de se montar as ligações. Os fragmentos purificados (100 ng) foram ligados aos plasmídeos pGEM-T (Kit pGEM-T Easy Vector System-Promega), segundo as especificações do fabricante.

Células competentes de Escherichia coli foram preparadas de acordo com o protocolo descrito por Sambrook et al. (1989) e depois transformadas com os plasmídeos recombinantes de acordo com o seguinte protocolo: $100 \mu \mathrm{l}$ de células foram incubados com 30 ng de plasmídeo recombinante por 15 minutos no gelo, em seguida a 
$37^{\circ} \mathrm{C}$ por 5 minutos e por mais 15 minutos no gelo; $250 \mu \mathrm{l}$ de meio LB foram acrescentados (à temperatura ambiente); seguiu-se uma incubação a $37^{\circ} \mathrm{C}$ sob agitação por uma hora; as células foram plaqueadas em meio LB-ágar com ampicilina $(0,15$ $\mathrm{mg} / \mathrm{ml})$ e X-Gal $(0,10 \mathrm{mg} / \mathrm{ml})$ e incubadas overnight a $37^{\circ} \mathrm{C}$. Colônias brancas (contendo plasmídeo recombinante) foram inoculadas em $5 \mathrm{ml}$ de meio LB e incubadas overnight a $37^{\circ} \mathrm{C}$ sob agitação.

Os plasmídeos recombinantes foram extraídos por meio do "PureLink Quick Plasmid Miniprep Kit” (Invitrogen) seguindo as orientações do fabricante. Para a verificação do tamanho do inserto, uma alíquota de $10 \%$ do volume de cada miniprep foi digerida com $5 \mathrm{U}$ da enzima de restrição Eco RI (New England-BioLabs), pois o vetor utilizado possui dois sítios de restrição para essa enzima flanqueando o inserto. Assim quando ocorre a digestão, o inserto é liberado do plasmídeo. Após uma hora de digestão, o processo foi interrompido e as digestões submetidas à eletroforese em gel de agarose $0,8 \%$ corados com brometo de etídeo e visualizados em um transiluminador UV. Foram considerados clones positivos os que apresentaram insertos independentemente dos seus tamanhos, pois após a digestão com Rsa I uma gama variada de fragmentos foi gerada.

\subsubsection{Sequenciamento, visualização das sequências e identificação dos}

\section{microssatélites:}

Os clones positivos foram sequenciados utilizando-se o conjunto de reagentes “Big Dye Terminator v.3.1” (Applied Biosystems). As concentrações de DNA molde e de primer seguiram as instruções do fabricante. 
As amostras foram analisadas em um seqüenciador automático, modelo ABIPRISM 3100 (Perkin Elmer), do Departamento de Química do IQ-USP. Foi utilizado nas reações, o primer universal complementar à região do plasmídeo (M13 forward).

A visualização das sequências geradas foi feita através do software Bioedit (Hall, 1999) e a busca por regiões repetitivas do tipo microssatélites foi realizada manualmente.

\subsubsection{Desenho dos primers:}

Para o desenho dos primers utilizamos a ferramenta eletrônica Primer3 (Rozen et al., 1998). Para isto, selecionamos sequências com base na qualidade upstream e downstream da repetição. Os primers foram sintetizados (Prodimol), diluídos para uma concentração estoque de $200 \mu \mathrm{M}$ em Tris $10 \mathrm{mM}$ pH 8,0 e armazenados a $-20^{\circ} \mathrm{C}$.

\subsubsection{Padronização das reações de PCR para a amplificação dos locos de microssatélites e resolução em géis de poliacrilamida:}

As reações foram realizadas em volumes de $20 \mu \mathrm{l}$ contendo: $14,7 \mu \mathrm{l}$ de água, 1 $\mu l$ de cada um dos dois tampões da reação de PCR (Fermentas), $1 \mu l$ de dNTPs 2 mM cada, $0,6 \mu \mathrm{l}$ de $\mathrm{MgCl}_{2} 50 \mathrm{mM}, 0,4 \mu \mathrm{l}$ de cada primer $20 \mu \mathrm{M}, 1 \mu \mathrm{l}$ da extração de DNA (Miniprep) e 0,3 $\mu 1$ de Taq DNA polimerase (Fermentas). Cada reação de PCR foi submetida inicialmente a uma desnaturação a $93^{\circ} \mathrm{C} / 4$ minutos, seguida por 35 ciclos de: [desnaturação a $94^{\circ} \mathrm{C} / 40$ s., hibridação dos primers a uma temperatura teste por $50 \mathrm{~s} \mathrm{e}$ extensão a $72^{\circ} \mathrm{C} / 40 \mathrm{~s}$.]. Ao final desses ciclos, um passo extra de extensão a $72^{\circ} \mathrm{C}$ por 10 minutos foi efetuado. Os produtos foram separados em gel de poliacrilamida $9 \%$ e corados com nitrato de prata e fotografados com auxílio de uma câmera digital. Foram feitos testes até que se conseguisse uma temperatura ótima de hibridação dos primers. 
Dos 18 pares de primers sintetizados, conseguimos a padronização de 12. Para avaliar o polimorfismo destes locos triamos 19 indivíduos das amostras coletadas em áreas externas ao campus USP-RP provenientes de diversas localidades. Vale ressaltar que os resultados da construção da biblioteca e da triagem desses 19 indivíduos foram recentemente aceitos para publicação na revista Apidologie (Apêndice 4). Destes 12 locos, selecionamos os 5 mais polimórficos para este estudo.

\subsubsection{Padronização das condições de PCR e triagem populacional com os} locos utilizados no estudo por análise de fragmentos em sequenciador automático

Devido à maior acurácia dos dados gerados por análise de fragmentos em sequenciador automático em relação aos géis de poliacrilamida, decidimos realizar as triagens populacionais por meio desta técnica. Deste modo, os 5 locos escolhidos tiveram que passar por uma nova etapa de padronização.

Para tanto, novos primers forward tiveram que ser sintetizados. Esses oligonucleotídeos possuem uma sequência adicional (Tag) na extremidade $5^{\prime}$ (5'TGTAAAACGACGGCCAGT-3'). Nessa sequência se liga o primer M13 (-21) marcado com os fluorocromos 6-FAM (azul), HEX (verde) ou NED (amarelo). Isso elimina a necessidade da marcação dos primers forward de cada loco. Devido à sequência Tag tínhamos uma nova cinética de reação na PCR, por isso a nova padronização foi necessária. Os detalhes se encontram abaixo.

As reações, tanto para a otimização quanto para a triagem populacional, foram realizadas em volumes de $5 \mu$ contendo: $2,35 \mu l$ de água; $0,5 \mu l$ de tampão 10X (Invitrogen); 0,5 $\mu \mathrm{l}$ de dNTPs (2 mM cada); 0,2 $\mu \mathrm{l}$ de $\mathrm{MgCl}_{2}(50 \mathrm{mM}) ; 0,125 \mu \mathrm{l}$ de um mix composto do primer forward tag $(0,5 \mu \mathrm{M})+$ primer reverse $(5 \mu \mathrm{M}) ; 0,125 \mu \mathrm{l}$ do 
primer M13 (-21) (5 $\mu \mathrm{M})$ marcado com o fluorocromo. Adicionou-se $1 \mu \mathrm{l}$ da extração como DNA molde; $0,1 \mu \mathrm{l}$ de Taq DNA polimerase $5 \mathrm{U} / \mu \mathrm{l}$ (Invitrogen) e $0,1 \mu \mathrm{l}$ de glicerol 50\%. Cada reação de PCR foi submetida inicialmente a uma desnaturação a $94^{\circ} \mathrm{C} / 4$ minutos, seguida por 35 ciclos de: [desnaturação a $94^{\circ} \mathrm{C} / 40$ segundos, hibridação dos primers a uma temperatura teste por 50 segundos e extensão a $72^{\circ} \mathrm{C} / 40$ segundos]. Ao final desses ciclos, um passo extra de extensão a $72{ }^{\circ} \mathrm{C}$ por 10 minutos foi efetuado. Foram realizadas tentativas até que se chegasse a uma nova temperatura ótima de hibridação dos primers. Após essa otimização, procedemos com a triagem de todas as amostras incluídas no estudo.

Os produtos da reação de PCR foram diluídos na proporção de 1:10 em $\mathrm{H}_{2} \mathrm{O}$ e $2 \mu \mathrm{l}$ dessa diluição foram misturados a $0,15 \mu \mathrm{l}$ do marcador de peso molecular GeneScan ROX 500 (Applied Biosystems) e 7,85 $\mu$ l de Formamida Hi-Di (Applied Biosystems). A análise foi realizada em um sequenciador automático, modelo ABIPRISM 3100 (Perkin Elmer) do Centro de Estudos do Genoma Humano do IB- USP.

\subsubsection{Análise das amostras}

Como mencionado anteriormente, escolhemos os cinco locos mais polimórficos isolados através da construção da biblioteca genômica para estudar as populações de $F$. varia, $F$. trichocerata e $F$. doederleini, que estavam distribuídas da seguinte maneira: $F$. varia campus USP $(\mathrm{n}=33) ; F$. varia amostras externas $(\mathrm{n}=36)$, sendo que estas últimas foram divididas em quatro grupos baseados em proximidade geográfica [GO-MT-MG (n=15), SP (n=13), MT (n=02) e MG (n=6)]; F. trichocerata $(\mathrm{n}=30)$ e $F$. doederleini (n=03). Para tanto, utilizamos o DNA extraído de um indivíduo por ninho amostrado, seguindo o protocolo de extração já descrito. 


\subsubsection{Análise dos dados}

Os arquivos de genotipagem provenientes do sequenciador automático foram visualizados através do programa GeneMarker v.1.85 (demo version) (SoftGenetics, StateCollege, PA). Os genótipos obtidos foram formatados para que se pudesse montar os arquivos de entrada de acordo com cada programa utilizado nas análises estatísticas dos dados.

Para o cálculo da taxa de heterozigose esperada $(\mathrm{He})$ e observada $(\mathrm{Ho})$ para cada loco, bem como a média dessas taxas, o número médio de alelos por locos, porcentagem de locos polimórficos a $95 \%$ e $99 \%$ foi utilizado o conjunto de planilhas do Microsoft Excel FOFpop v.2.0 (Francisco, 2009). Para realizar os cálculos do Equilíbrio de Hardy-Weinberg, frequência alélica, desequilíbrio de ligação e o teste exato de Fisher, foi usado o programa GENEPOP v.3.4 (Raymond e Rousset, 1995b). O programa GENALEX v.6 (Peakall et al., 2006) foi usado para realizar uma análise de “assign” com os genótipos encontrados. 


\subsection{Análise morfométrica das asas}

Para esta etapa foram montadas em lâminas de microscopia as asas anteriores direitas de aproximadamente 10 indivíduos de cada ninho amostrado. A retirada das asas para a montagem foi feita com o auxílio de pinças. Posteriormente essas lâminas foram cobertas com lamínulas de vidro e vedadas com massa de modelar (Figura 9).

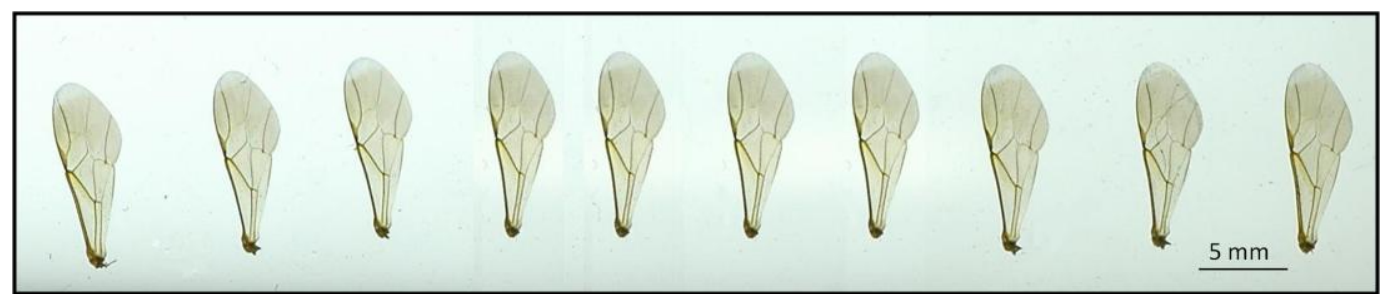

Figura 9: Imagem ampliada de uma lâmina montada.

Cada uma das 10 asas por lâmina foi fotografada com uma câmera digital (Leica DFC280), acoplada a um estereomicroscópio (Leica MZ75) e então essas imagens foram capturadas pelo programa Leica Soft IM50. As imagens foram convertidas em arquivos *.tps utilizando o programa tpsUtil v.1.33 (Rohlf, 2004). No programa tpsDig v.2.04 (Rohlf, 2005a) foram marcados manualmente, em cada asa, onze pontos anatômicos homólogos para a posterior análise de "relative warps" através do software tpsRelw versão 2.04 (Rohlf, 2005b) (Figura 10).

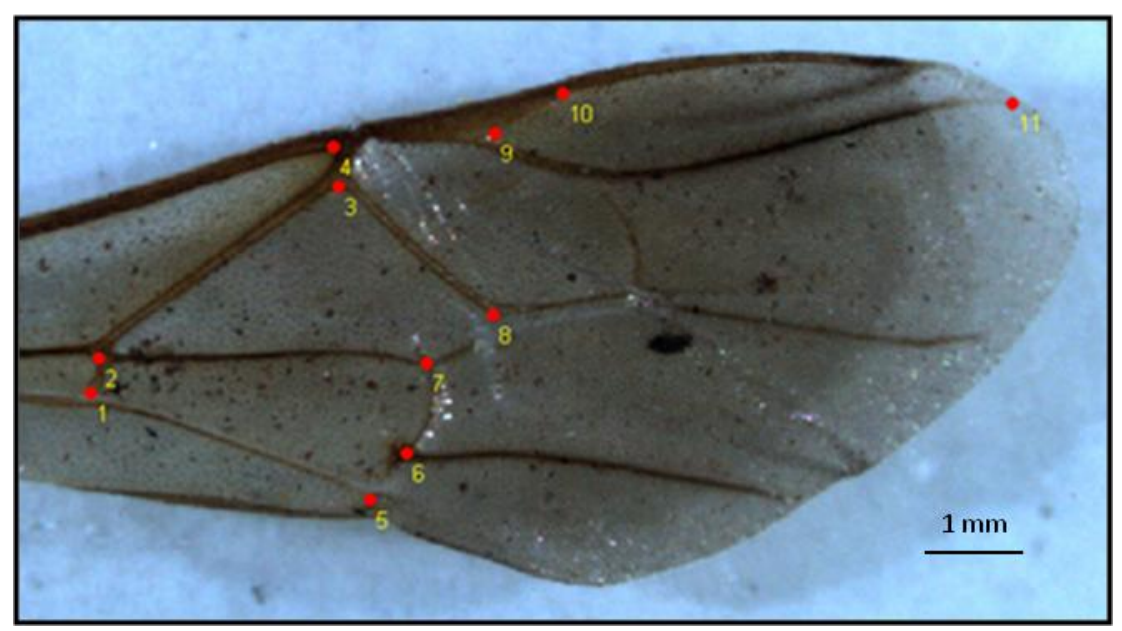

Figura 10: Interface do software tpsDig mostrando a imagem de uma asa e os 11 pontos marcados. 


\subsubsection{Análise dos dados}

Os resultados provenientes das análises de morfometria geométrica foram processados por cálculos discriminantes lineares, bem como distâncias lineares quadráticas de Mahalanobis entre os grupos com o auxílio do software Statistica 6.0 (Statsoft inc., 2003). Com os valores de distância de Mahalanobis foi construída uma árvore de proximidade morfológica com o auxílio do programa MEGA v.4.0 (Tamura et al., 2007). 


\section{Resultados}

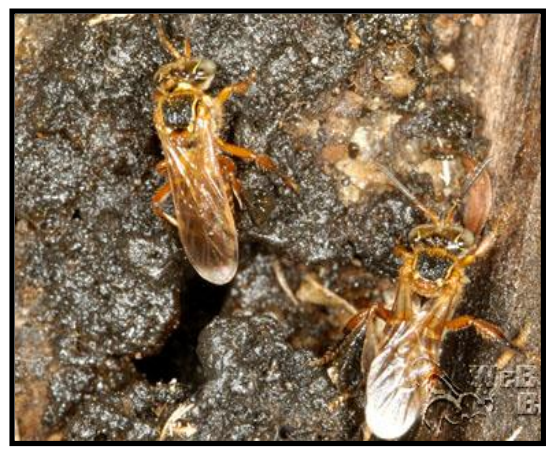




\subsection{PCR-RFLP do DNA mitocondrial}

Foram amplificadas cinco regiões do DNA mitocondrial de Frieseomelitta varia (Figura 11) totalizando 6.430 pares de bases (pb), que correspondem à cerca de $34,75 \%$ do total de bases desse genoma, o qual foi estimado em aproximadamente 18.500 pb para o gênero Plebeia e Melipona (Francisco et al., 2001; Weinlich et al., 2004).

Os padrões de corte para as regiões estudadas estão listados na Tabela 27 e os haplótipos compostos nas Tabelas 29 e 30 (Apêndice 2). Das 15 enzimas de restrição utilizadas no estudo, três ( $B a m$ HI, $B g l$ II e Hae III) não apresentaram sítio de corte em nenhuma das regiões analisadas. Portanto, os haplótipos compostos foram formados por 12 letras, cada uma correspondendo a uma enzima de restrição e seu padrão de corte combinado para as cinco regiões. A combinação destes diversos padrões de corte gerou um total de 21 haplótipos compostos (Tabela 4). Os haplótipos identificados por PCR+RFLP foram denominados de "Hr" (ex.: $\mathrm{Hr} 01, \mathrm{Hr} 02$ etc).

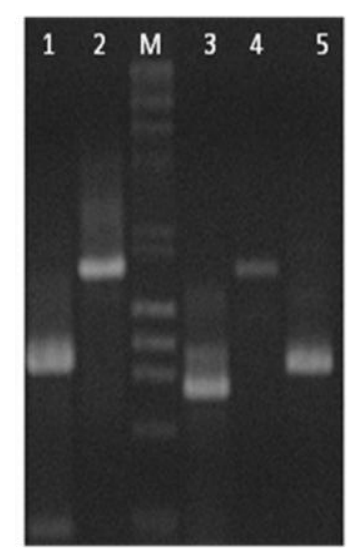

Figura 11: Gel de agarose $0,8 \%$ mostrando a amplificação das 5 regiões estudadas de $F$. varia, $F$. trichocerata e $F$. doederleini. 1 [COII]; 2 - [ATPase $6 \mathrm{e}$ 8/COIII]; M - Marcador de peso molecular $\lambda /$ Hind $\mathrm{III}+\mathrm{PhiX} / \mathrm{Hae}$ III; 3 [NDI/16S]; 4 - [16S/12S] e 5 - [COI]. 
Tabela 4: Haplótipos e suas composições (combinação dos padrões de corte para as 12 enzimas de restrição) obtidos para $F$. varia, $F$. trichocerata $(F . t$ ), $e$ F. doederleini (F.d.). Populações amostradas (ver Material e Métodos), número amostral (n) e número de haplótipos por grupo de amostras são mostrados.

Em vermelho são apresentados os haplótipos encontrados para $F$. varia (campus USP e amostras externas); em verde os haplótipos para $F$. trichocerata; e em azul o haplótipo de $F$. doederleini.

\begin{tabular}{|c|c|c|c|c|c|c|c|c|}
\hline \multirow[b]{3}{*}{ HAPLÓTIPO } & \multirow[b]{3}{*}{ НАР. COMPOSTO } & \multicolumn{5}{|c|}{ Frieseomelitta varia } & \multirow[b]{3}{*}{$\begin{array}{c}\boldsymbol{F} . \boldsymbol{t} . \\
\mathrm{n}=30\end{array}$} & \multirow[b]{3}{*}{$\begin{array}{l}\text { F. } \boldsymbol{d} . \\
\mathrm{n}=3\end{array}$} \\
\hline & & \multirow[b]{2}{*}{$\begin{array}{c}\text { C. USP } \\
n=33\end{array}$} & \multicolumn{4}{|c|}{ Amostras externas ao campus USP } & & \\
\hline & & & $\begin{array}{c}\text { GO-MT- MG } \\
n=15\end{array}$ & $\begin{array}{c}\text { SP } \\
n=13\end{array}$ & $\begin{array}{c}\text { MT } \\
n=02\end{array}$ & $\begin{array}{c}\mathbf{M G} \\
n=06\end{array}$ & & \\
\hline Hr01 & AAAAAAAAAAAA & 15 & - & - & - & - & - & - \\
\hline Hr02 & AAAAAAAАAАВА & 02 & - & - & - & - & - & - \\
\hline Hr03 & ААААВАААAАAА & 05 & - & - & - & - & - & - \\
\hline Hr04 & AАAАВАААВАAА & 01 & - & - & - & - & - & - \\
\hline Hr05 & AABAABACACAA & 02 & - & - & - & - & - & - \\
\hline Hr06 & BAAABAAABAAA & 01 & - & - & - & - & - & - \\
\hline Hr07 & CAAAAAAAAAAA & 01 & - & - & - & - & - & - \\
\hline Hr08 & CAAAAAABABAA & 05 & - & - & - & - & - & - \\
\hline Hr09 & CAAABAABAAAA & 01 & - & - & - & - & - & - \\
\hline Hr10 & CAABBAAABADA & - & 03 & 11 & - & 03 & - & - \\
\hline Hr11 & CABAABACACAA & - & 02 & - & - & - & - & - \\
\hline Hr12 & CABABBACACAA & - & 03 & - & - & - & - & - \\
\hline Hr13 & DAAABAAABAAA & - & 02 & - & 01 & - & - & - \\
\hline Hr14 & DAABBAAABADA & - & - & - & - & - & 01 & - \\
\hline Hr15 & DAABBAADBABA & - & - & - & 01 & - & - & - \\
\hline Hr16 & DAABBAADBACA & - & 05 & 01 & - & 03 & - & - \\
\hline Hr17 & EAAABAAABAAA & - & - & 01 & - & - & - & - \\
\hline Hr18 & FAABBAAABADA & - & - & - & - & - & - & 03 \\
\hline Hr19 & FAABBABABDEA & - & - & - & - & - & 15 & - \\
\hline Hr20 & GAAABAAABAAA & - & - & - & - & - & 12 & - \\
\hline Hr21 & HBACBACEBAFA & - & - & - & - & - & 02 & - \\
\hline
\end{tabular}


Dentre as amostras do campus USP foram identificados nove haplótipos (Hr01 a Hr09) (Figura 12) enquanto que nas amostras externas sete. Para as amostras de $F$. trichocerata foram encontrados quatro haplótipos exclusivos desta espécie ( $\mathrm{Hr} 14, \operatorname{Hr} 19$ a $\operatorname{Hr} 21)$ e para $F$. doederleini foi encontrado apenas um, e exclusivo, haplótipo (Hr18). As figuras 12 e 13 apresentam os haplótipos verificados e suas distribuições por localidade. Vale ressaltar o compartilhamento dos haplótipos Hr10 e Hr16 entre 3 áreas amostradas (GO-MT-MG, MG e SP), ainda, em MG foram os dois único haplótipos verificados.

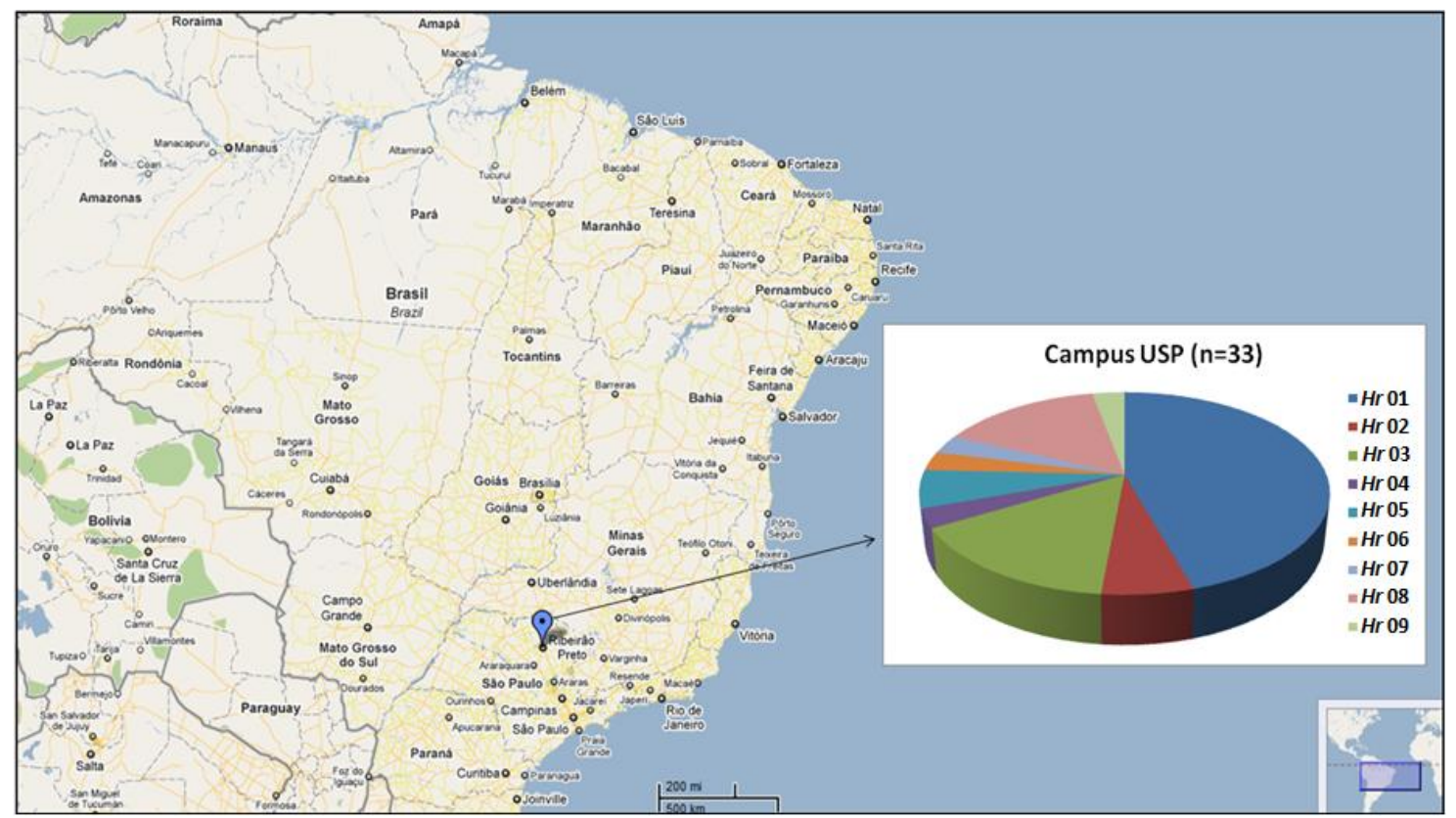

Figura 12: Mapa parcial do Brasil indicando a localização do campus da USP de Ribeirão Preto e as proporções dos haplótipos encontrados nas amostras de $F$. varia. Hr01-46\%; HrO2-6\%; $\mathrm{Hr} 03-15 \%$; Hr04-3\%; Hr05-6\%; Hr06-3\%; Hr07-3\%; Hr08-15\%; Hr09-3\%. 


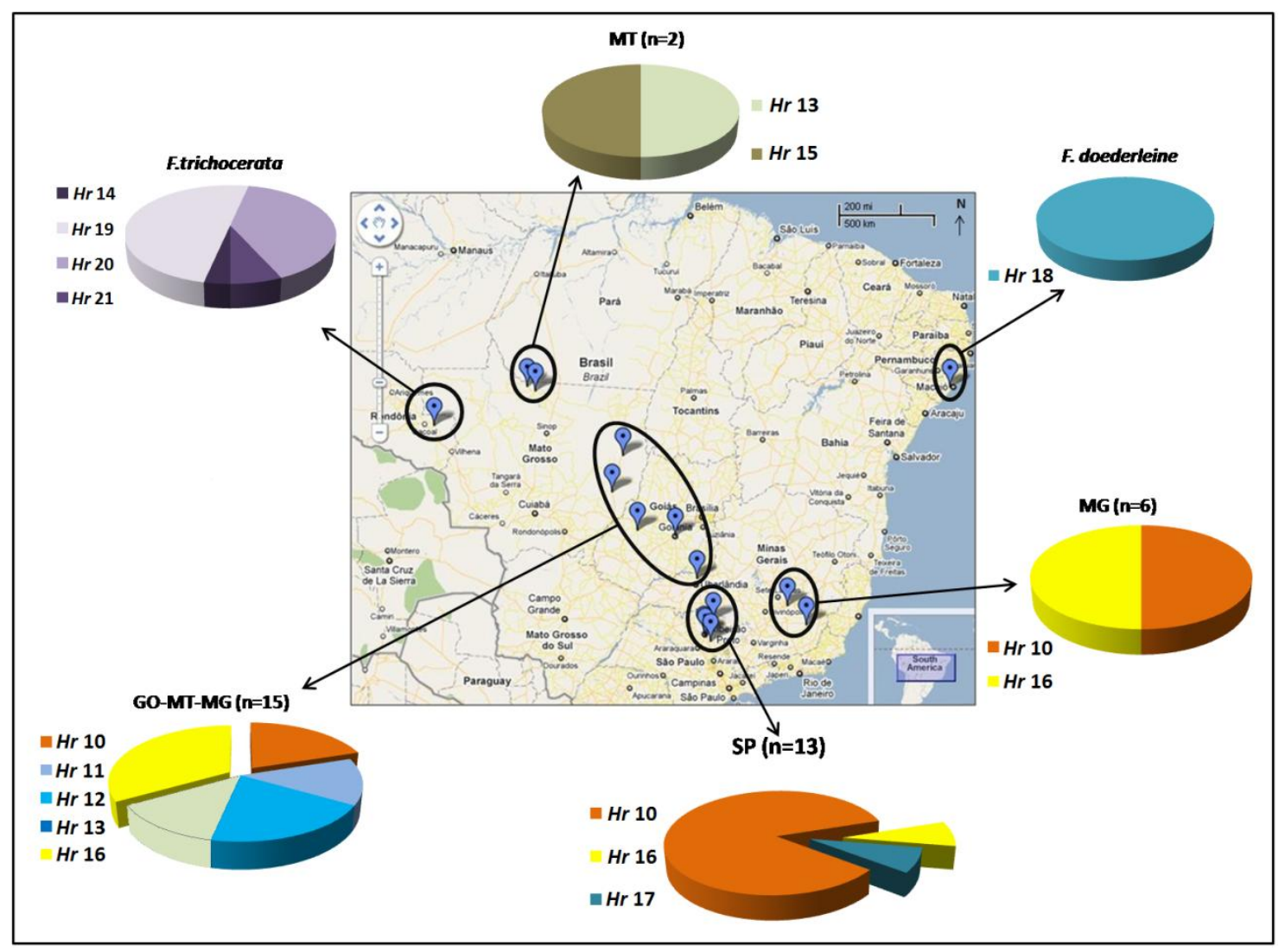

Figura 13: Mapa parcial do Brasil indicando os locais de coleta das 3 espécies, os haplótipos identificados e suas proporções. Frequências dos haplótipos de $F$. varia externas ao campus: [GO-MT-MG (Hr10-20\%; Hr11-13\%; Hr12-20\%; Hr13-13\%; Hr16-34\%)]; SP [(Hr10-84\%; Hr16-8\%; Hr17-8\%)]; [MT (Hr13-50\%; Hr15-50\%)]; [MG (Hr10-50\%; Hr16-50\%)]; [F. trichocerata (Hr14-3\%; Hr19-50\%; Hr20-40\%; Hr21-7\%)]; [F. doederleini (Hr21-100\%)].

As distâncias evolutivas representadas pelas divergências de sequências nucleotídicas $(d)$ entre os 21 haplótipos são apresentadas na Tabela 5.

A média dos valores de diversidade haplotípica $(h)$ entre pares de populações foi de 0,5196 +/- 0,016 e a média de diversidade nucleotídica (p) foi de 0,000835 +/0000001, indicando que os haplótipos são muito semelhantes entre si (Tabela 6). Uma rede de haplótipos foi construída pelo método Median-Joining (Figura 14) implantado no software Network v. 4.5.1.0 (Polzin e Daneschmand, 2003). 
Tabela 5: Divergência de sequência de nucleotídeos $(d)$ par a par entre os 21 haplótipos totais encontrados entre as espécies $F$. varia $(\mathrm{Hr} 01$ a Hr13, Hr15 a $\mathrm{Hr} 17), F$ trichocerata $(\mathrm{Hr} 14, \mathrm{Hr} 19$ a $\mathrm{Hr} 21)$ e $F$. doederleini $(\mathrm{Hr} 18)$. Valores em porcentagem*.

\begin{tabular}{|c|c|c|c|c|c|c|c|c|c|c|c|c|c|c|c|c|c|c|c|c|}
\hline & Hr01 & Hr02 & Hr03 & Hr04 & Hr05 & Hr06 & Hr07 & Hr08 & Hr09 & Hr10 & Hr11 & Hr12 & Hr13 & Hr14 & Hr15 & Hr16 & Hr17 & Hr18 & Hr19 & Hr20 \\
\hline Hr02 & 0,418 & & & & & & & & & & & & & & & & & & & \\
\hline Hr03 & 0,159 & 0,259 & & & & & & & & & & & & & & & & & & \\
\hline Hr04 & 0,245 & 0,681 & 0,418 & & & & & & & & & & & & & & & & & \\
\hline Hr05 & 0,118 & 0,538 & 0,281 & 0,371 & & & & & & & & & & & & & & & & \\
\hline Hr06 & 0,405 & 0,241 & 0,241 & 0,676 & 0,279 & & & & & & & & & & & & & & & \\
\hline Hr07 & 1,028 & 0,853 & 0,853 & 1,327 & 0,890 & 0,675 & & & & & & & & & & & & & & \\
\hline Hr08 & 0,733 & 0,903 & 0,903 & 1,005 & 0,853 & 0,981 & 0,272 & & & & & & & & & & & & & \\
\hline Hr09 & 0,903 & 0,733 & 0,733 & 1,192 & 1,028 & 0,806 & 0,114 & 0,154 & & & & & & & & & & & & \\
\hline Hr10 & 0,238 & 0,661 & 0,406 & 0,500 & 0,116 & 0,399 & 1,013 & 0,976 & 1,156 & & & & & & & & & & & \\
\hline Hr11 & 0,582 & 0,661 & 0,406 & 0,878 & 0,446 & 0,399 & 1,013 & 1,345 & 1,156 & 0,316 & & & & & & & & & & \\
\hline Hr12 & 0,939 & 0,932 & 0,750 & 0,670 & 0,790 & 0,657 & 1,296 & 1,654 & 1,451 & 0,650 & 0,563 & & & & & & & & & \\
\hline Hr13 & 0,446 & 0,530 & 0,277 & 0,726 & 0,316 & 0,275 & 0,877 & 1,194 & 1,013 & 0,193 & 0,115 & 0,433 & & & & & & & & \\
\hline Hr14 & 0,767 & 0,837 & 0,582 & 0,684 & 0,623 & 0,568 & 1,194 & 1,545 & 1,345 & 0,485 & 0,400 & 0,235 & 0,273 & & & & & & & \\
\hline Hr15 & 0,843 & 0,842 & 0,660 & 0,857 & 0,699 & 0,570 & 1,203 & 1,551 & 1,353 & 0,563 & 0,478 & 0,155 & 0,352 & 0,235 & & & & & & \\
\hline Hr16 & 0,277 & 0,699 & 0,446 & 0,541 & 0,155 & 0,437 & 1,050 & 1,013 & 1,194 & 0,038 & 0,355 & 0,689 & 0,231 & 0,525 & 0,602 & & & & & \\
\hline Hr17 & 0,485 & 0,568 & 0,316 & 0,767 & 0,355 & 0,313 & 0,913 & 1,231 & 1,050 & 0,231 & 0,152 & 0,471 & 0,037 & 0,312 & 0,390 & 0,190 & & & & \\
\hline Hr18 & 4,030 & 4,177 & 3,839 & 3,932 & 3,705 & 3,636 & 4,786 & 5,370 & 5,150 & 3,410 & 3,249 & 3,414 & 3,294 & 3,410 & 3,414 & 3,455 & 3,339 & & & \\
\hline Hr19 & 0,726 & 0,798 & 0,541 & 0,642 & 0,582 & 0,529 & 1,156 & 1,506 & 1,307 & 0,446 & 0,446 & 0,276 & 0,316 & 0,038 & 0,276 & 0,485 & 0,355 & 3,364 & & \\
\hline Hr20 & 0,920 & 0,983 & 0,726 & 0,835 & 0,767 & 0,706 & 1,345 & 1,716 & 1,506 & 0,623 & 0,533 & 0,357 & 0,400 & 0,116 & 0,357 & 0,663 & 0,439 & 3,204 & 0,017 & \\
\hline Hr21 & 1,138 & 1,121 & 0,939 & 1,484 & 0,980 & 0,929 & 1,383 & 1,763 & 1,548 & 0,830 & 0,739 & 0,919 & 0,602 & 0,739 & 0,828 & 0,870 & 0,640 & 3,576 & 0,869 & 0,611 \\
\hline
\end{tabular}


Tabela 6: Número de haplótipos, valores de diversidade haplotípica $(h)$ e nucleotídica (p) para cada grupo de amostras.

\begin{tabular}{c|c|ccc}
\hline \multicolumn{2}{c}{ Amostras } & $\mathbf{N}^{\mathbf{0}}$ de haplótipos & $\boldsymbol{h}$ & $\mathbf{p}$ \\
\hline \multirow{5}{*}{ F. varia } & Campus USP & 9 & 0,74780 & 0,000402 \\
& GO-MT-MG & 5 & 0,03503 & 0,001943 \\
& SP & 3 & 0,10948 & 0,000975 \\
MT & 2 & 0,20412 & 0,000000 \\
MG & 2 & 0,06155 & 0,001553 \\
& F. trichocerata & 4 & 0,03505 & 0,000972 \\
F. doederleini & 1 & 0,00000 & 0,000000 \\
\hline \multicolumn{2}{c}{ Média } & 3,7 & 0,51960 & 0,000835 \\
\hline
\end{tabular}

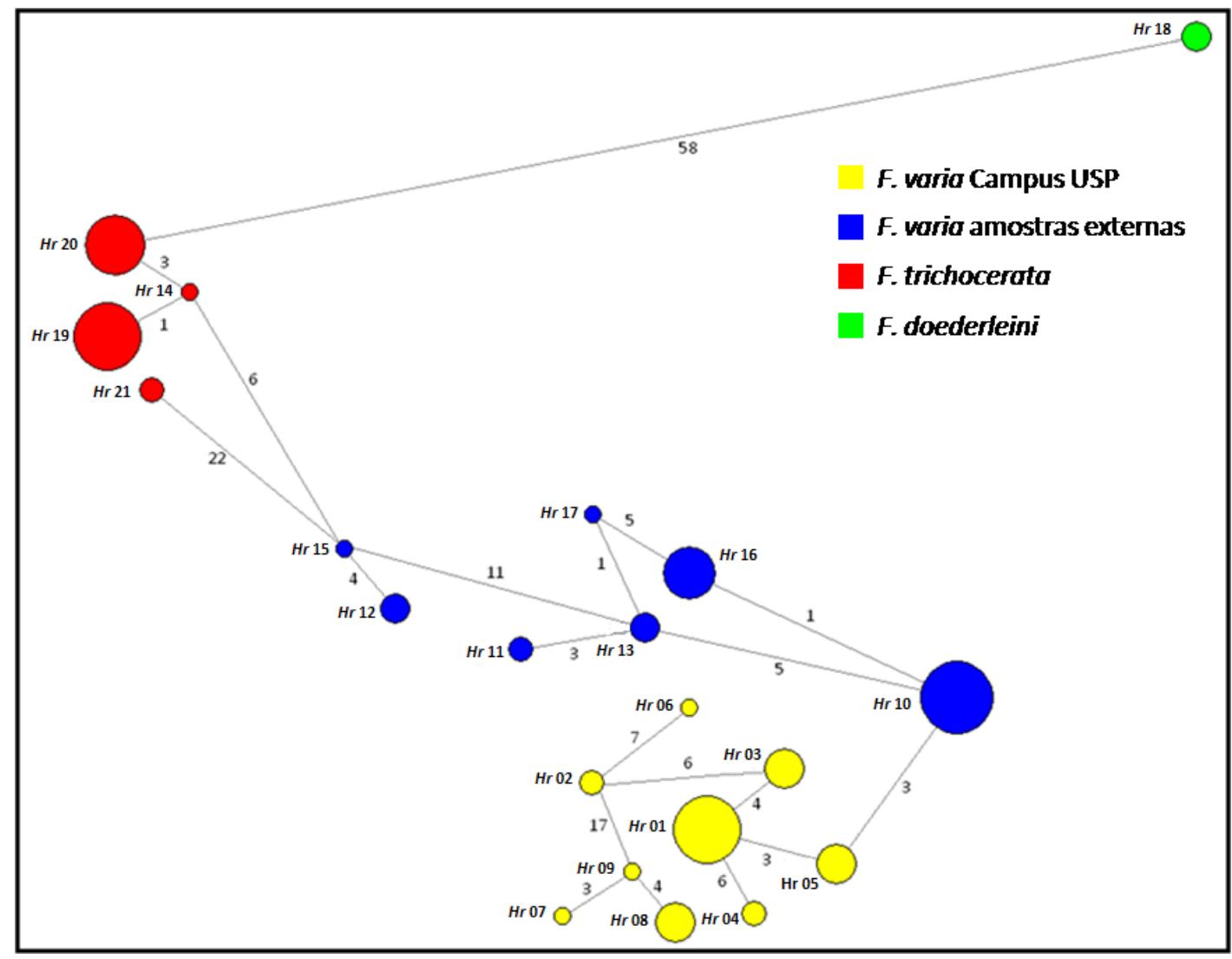

Figura 14: Rede de inter-relações entre os 21 haplótipos encontrados para $F$. varia, $F$. trichocerata e $F$. doederleini através do RFLP do DNA mitocondrial. Os números próximos aos ramos que interligam os haplótipos correspondem ao número de passos mutacionais que diferenciam estes haplótipos. 
A análise de divergência de sequência de nucleotídeos (d) entre pares de grupos amostrais revelou que as amostras de $F$. varia mais próximas foram SP e MG $(0,015)$. Em contrapartida, as populações mais divergentes foram campus USP e SP (0,295). Porém quando analisamos as três espécies incluídas neste estudo, os grupos mais próximos continuaram sendo SP/MG e os mais divergentes foram campus USP e F. doederleini. A Tabela 7 mostra os valores de "d".

Tabela 7: Porcentagem de divergência de sequência de nucleotídeos (d) entre pares de grupos amostrais de F. varia, F. trichocerata (F.t.) e F. doederleini (F.d.).

\begin{tabular}{ccccccc} 
& \multicolumn{5}{c}{ F. varia } & \\
\cline { 2 - 5 } & \multicolumn{5}{c}{ Amostras externas ao campus USP } & \multirow{2}{*}{ F.t. } \\
\cline { 2 - 6 } GO-MT-MG & C.USP & GO-MT-MG & SP & MT & MG & \\
SP & 0,067 & & & & & \\
MT & 0,295 & 0,110 & & & & \\
MG & 0,150 & 0,024 & 0,183 & & & \\
F.t. & 0,194 & 0,024 & 0,015 & 0,052 & & \\
F.d. & 0,025 & 0,070 & 0,309 & 0,165 & 0,208 & \\
\hline
\end{tabular}




\subsection{Sequenciamento do gene $C O I$}

As reações de PCR realizadas produziram fragmentos do tamanho esperado (aproximadamente $600 \mathrm{pb}$ ) e sem a presença de bandas inespecíficas. No total 102 indivíduos foram analisados (um por ninho amostrado). Cerca de 500 bases por amostra foram obtidas, porém após o alinhamento das sequências, a matriz de dados foi reduzida para 395 bases. A partir desta matriz, o programa DNAsp v.5 produziu uma tabela de sítios polimórficos, identificando 38 sítios variáveis e 14 haplótipos distintos (Tabela 8). A tradução das sequências em aminoácidos revelou a ausência de códons de parada em todas as sequências. Os haplótipos identificados, para a região COI, por sequenciamento foram denominados de "Hs" (ex.: Hs01, Hs02 etc).

Dos quatorze haplótipos, nove foram encontrados somente nas amostras de $F$. varia, tanto de amostras do campus USP, quanto de amostras externas (Hs03, $\mathrm{Hs} 04$, Hs05, Hs06, Hs07, Hs08, Hs10, Hs13 e Hs14), três em F. trichocerata (Hs09, Hs11 e Hs12) e dois em F. doederleini (Hs01 e Hs02) (Tabela 9). 
Tabela 8: Sítios variáveis encontrados com o sequenciamento de um trecho do gene mitocondrial Citocromo Oxidase Subunidade I (COI) compondo cada um dos 14 haplótipos encontrados para as amostras de F. varia (Campus USP e amostras externas), F. trichocerata e F. doederleini.

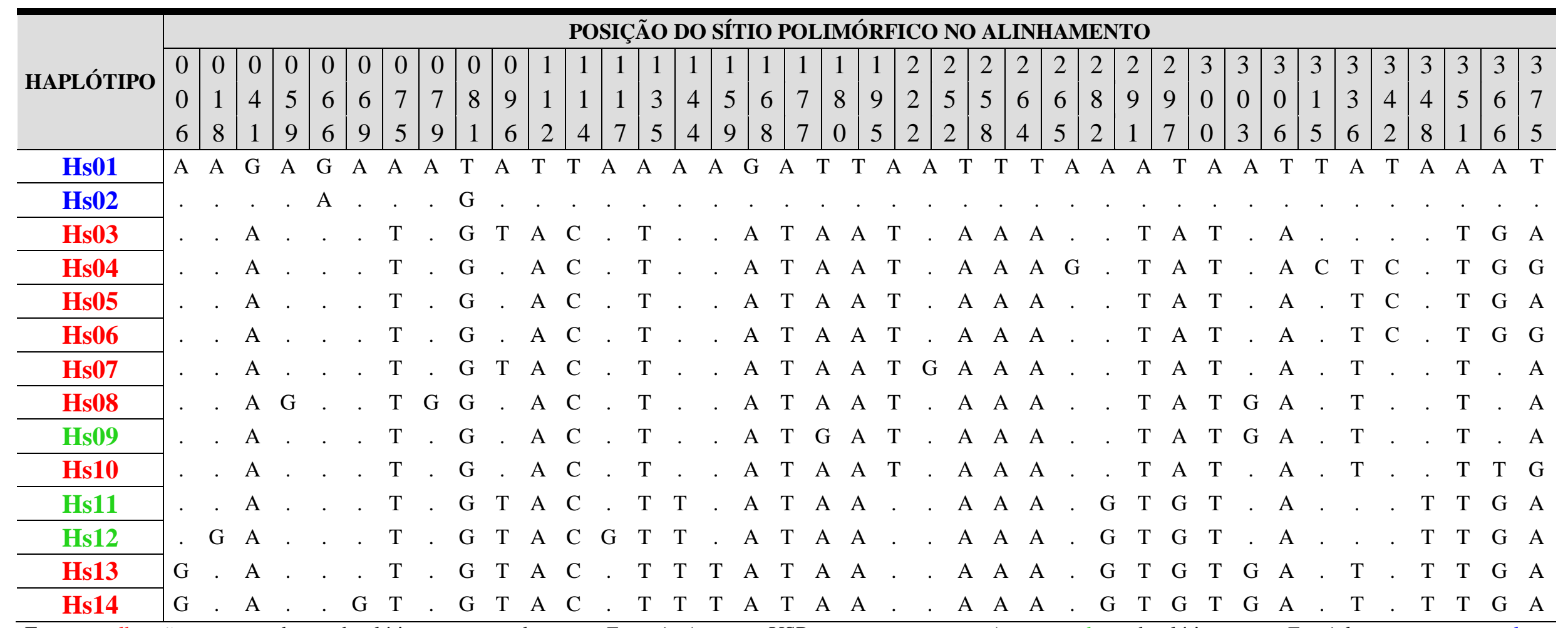

Em vermelho são apresentados os haplótipos encontrados para $F$. varia (campus USP e amostras externas); em verde os haplótipos para $F$. trichocerata e em azul os haplótipos para F. doederleini. 
Tabela 9: Distribuição dos haplótipos encontrados pelo sequenciamento do gene $C O \mathrm{I}$ para as amostras de $F$. varia (campus USP e amostras externas), $F$. trichocerata e $F$. doederleini.

\begin{tabular}{|c|c|c|c|c|c|c|c|}
\hline \multirow[b]{3}{*}{ Haplótipo } & \multicolumn{5}{|c|}{ Frieseomelitta varia } & \multirow[b]{3}{*}{$\begin{array}{l}\boldsymbol{F} . \boldsymbol{t} . \\
\mathrm{n}=33\end{array}$} & \multirow[b]{3}{*}{$\begin{array}{l}\text { F.d } \\
\mathrm{n}=3\end{array}$} \\
\hline & \multirow[b]{2}{*}{$\begin{array}{c}\text { C. USP } \\
n=33\end{array}$} & \multicolumn{4}{|c|}{ Amostras externas ao campus USP } & & \\
\hline & & 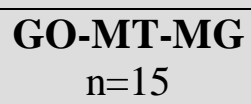 & $\begin{array}{c}\mathbf{S P} \\
\mathrm{n}=13\end{array}$ & $\begin{array}{l}\text { MT } \\
\mathrm{n}=2\end{array}$ & $\begin{array}{l}\text { MG } \\
n=6\end{array}$ & & \\
\hline Hs01 & - & - & - & - & - & - & 01 \\
\hline Hs02 & - & - & - & - & - & - & 02 \\
\hline Hs03 & - & - & 01 & - & - & - & - \\
\hline Hs04 & 03 & - & - & - & - & - & - \\
\hline Hs05 & 23 & 07 & 11 & - & 06 & - & - \\
\hline Hs06 & - & 01 & - & - & - & - & - \\
\hline Hs07 & 07 & 02 & 01 & - & - & - & - \\
\hline Hs08 & - & - & - & 01 & - & - & - \\
\hline Hs09 & - & - & - & - & - & 02 & - \\
\hline Hs10 & - & 02 & - & - & - & - & - \\
\hline Hs11 & - & - & - & - & - & 15 & - \\
\hline Hs12 & - & - & - & - & - & 13 & - \\
\hline Hs13 & - & 03 & - & - & - & - & - \\
\hline Hs14 & - & - & - & 01 & - & - & - \\
\hline
\end{tabular}

Em vermelho são apresentados os haplótipos encontrados para $F$. varia (campus USP e amostras externas); em verde os haplótipos para $F$. trichocerata; e em azul os haplótipos para $F$. doederleini.

Para a espécie $F$. varia, verificamos três haplótipos nas amostras do campus USP (H04, H05 e H07) (Tabela 9 e Figura 15), sendo um exclusivo (H04) e dois (H05 e H07) compartilhados com algumas localidades externas ao campus. As amostras externas apresentaram ainda outros sete haplótipos, sendo todos exclusivos (H03, H04, H06, H08, H10, H13 e H14). O haplótipo H05 foi o mais frequente, tanto na população do campus USP quanto nas amostras externas e o único haplótipo encontrado na população MG. Os haplótipos H05 e H07 foram os únicos compartilhados entre 3 e 4 localidades, respectivamente. A Tabela 9 e a Figura 16 apresentam esses resultados. 


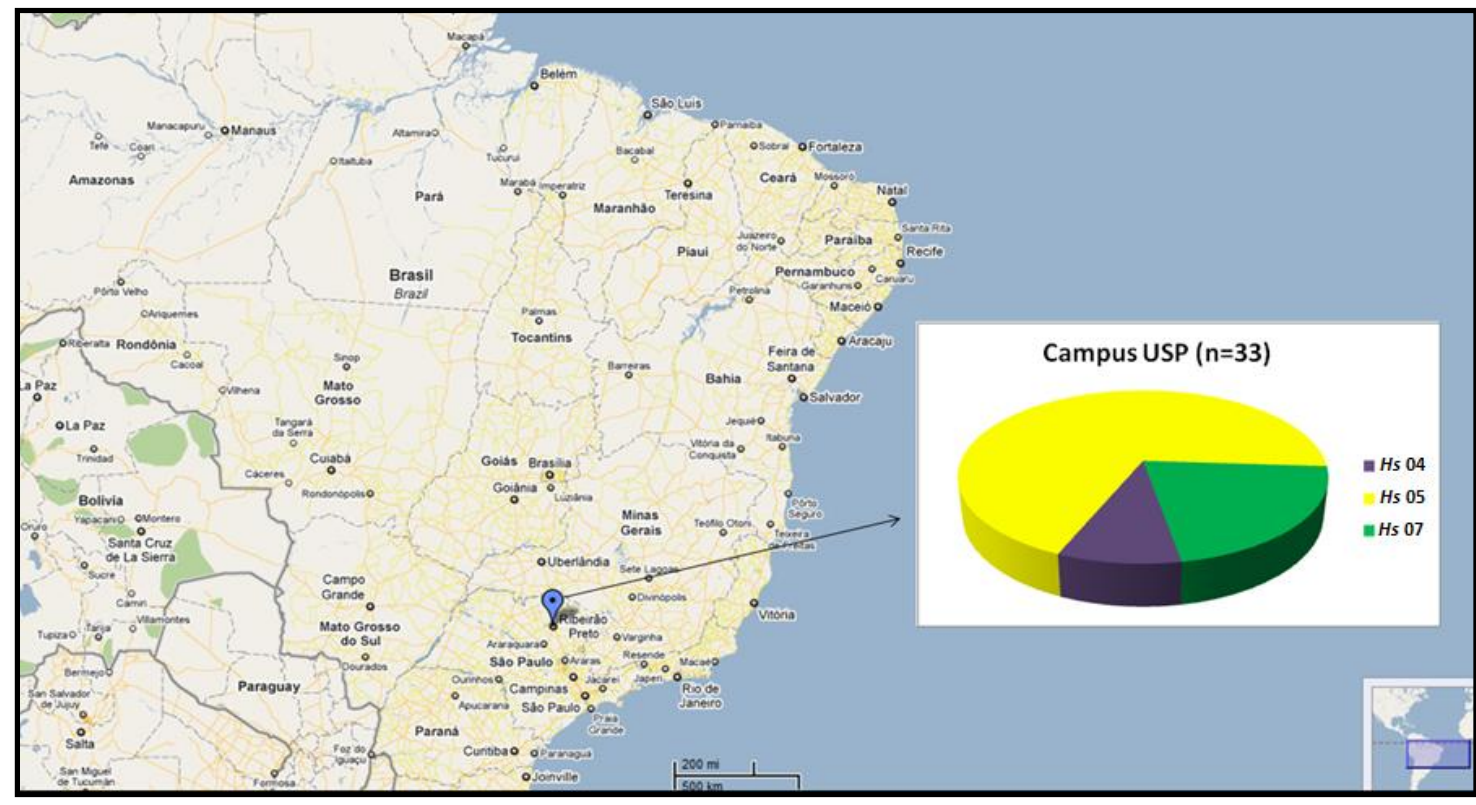

Figura 15: Mapa parcial do Brasil indicando a localização do campus da USP de Ribeirão Preto e as proporções dos 3 haplótipos encontrados para nas amostras de $F$. varia. Frequências: Hs04-9\%; Hs05-70\%; Hs07-21\%.

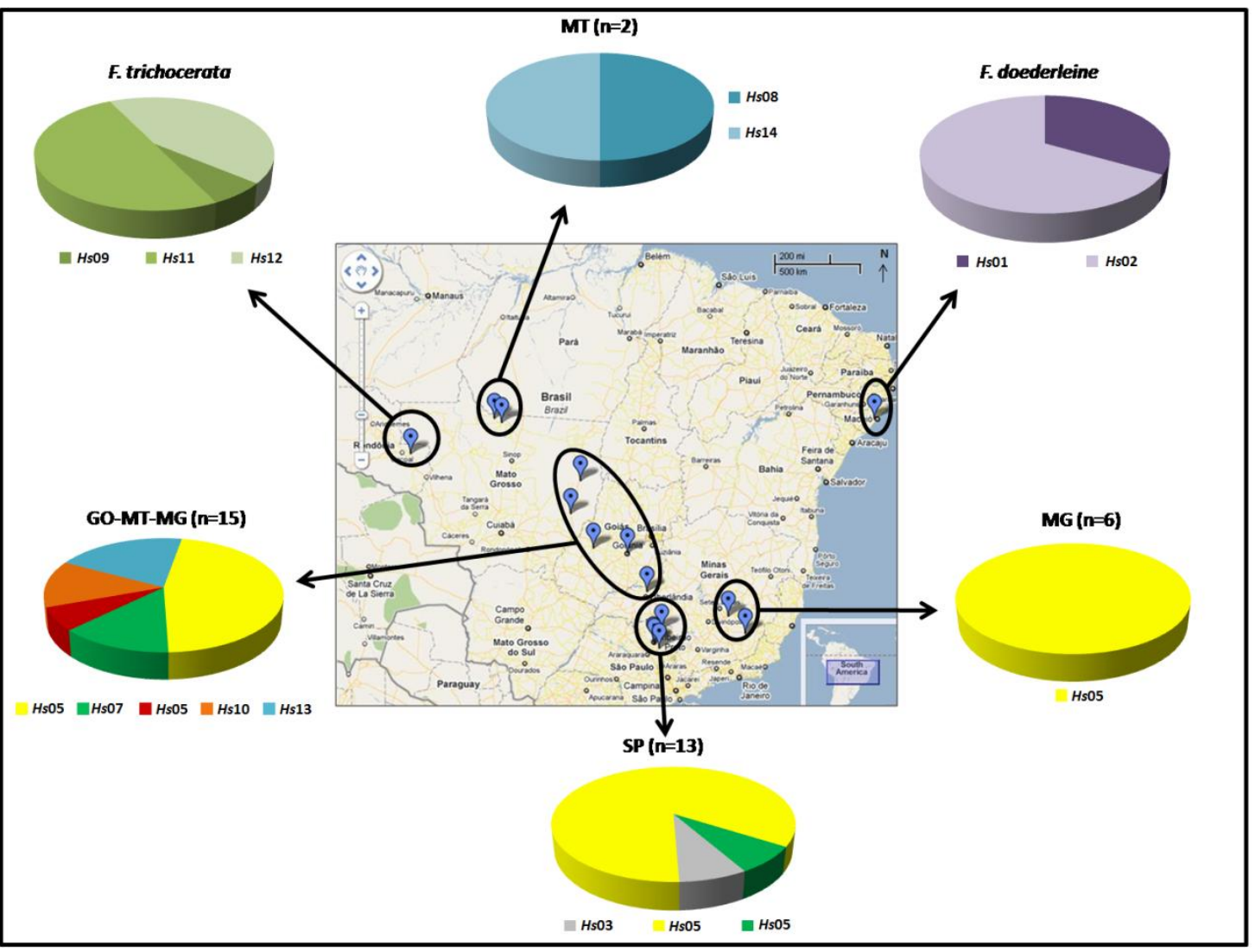

Figura 16: Mapa parcial do Brasil mostrando a distribuição e proporção dos haplótipos encontrados para $F$. varia (somente amostras externas), $F$. trichocerata e $F$. doederleini. Frequências dos haplótipos: GO-MT-MG (Hs05-47\%; Hs06-7\%; Hs07-13\%; Hs10-13\%; Hs1320\%). SP (Hs03-8\%; Hs05-84\%; Hs07-8\%). MT (Hs08-50\%; Hs 14-50\%). MG (Hs5 100\%). F. trichocerata (Hs09-7\%; Hs11-50\%; Hs12-43\%). F. doederleini (Hs01-33\%; Hs02-67\%). 
Os valores de diversidade haplotípica $(h)$ e nucleotídica $(\pi)$ foram de 0,744 e 0,015 respectivamente e o número médio de diferenças nucleotídicas entre os 14 haplótipos encontrados $(k)$ foi de 6,233 (para as três espécies estudadas). Os valores de divergência de sequência entre os pares de haplótipos estão listados na Tabela 10. Entre os grupos baseados em proximidade geográfica das amostras os valores de diversidade nucleotídica variaram de 0,00000 (MG) a 0,03038 (MT). Em relação às substituições de bases, o número de transições foi maior que o de transversões entre os haplótipos, exceto entre os haplótipos de F. doederleini (2 haplótipos com apenas duas substituições sendo uma transição e uma transversão) e de $F$. varia das amostras do campus USP. A composição nucleotídica entre os haplótipos de COI se manteve aproximadamente constante. O conteúdo médio de A+T foi de 77,61\%. Esses e outros dados de diversidade molecular estão sumarizados na Tabela 11. As relações entre os 14 haplótipos foram analisadas através dos métodos de median-joining e de Neighbor Joining implementados nos programas Network v. 4.5.1.0 (Polzin e Daneschmand, 2003) e MEGA v.4.0 (Tamura et al., 2007), respectivamente. Os resultados estão apresentados nas figuras 17 e 18.

Tabela 10: Estimativa de divergência de sequência (\%) entre pares de haplótipos encontrados para $F$. varia (em vermelho), $F$. trichocerata (em verde) e $F$. doederleini (em azul).

\begin{tabular}{l|rrlllllllllll}
\hline \hline & Hs01 & Hs02 & Hs03 & Hs04 & Hs05 & Hs06 & Hs07 & Hs08 & Hs09 & Hs10 & Hs11 & Hs12 & Hs13 \\
\hline Hs02 & 0,21 & & & & & & & & & & & & \\
Hs03 & 2,67 & 2,66 & & & & & & & & & & & \\
Hs04 & 3,07 & 3,06 & 0,66 & & & & & & & & & & \\
Hs05 & 2,81 & 2,79 & 0,33 & 0,32 & & & & & & & & & \\
Hs06 & 2,81 & 2,79 & 0,44 & 0,21 & 0,11 & & & & & & & & \\
Hs07 & 2,81 & 2,79 & 0,32 & 0,77 & 0,43 & 0,54 & & & & & & & \\
Hs08 & 2,92 & 2,90 & 0,65 & 0,87 & 0,54 & 0,65 & 0,54 & & & & & & \\
Hs09 & 2,67 & 2,66 & 0,54 & 0,76 & 0,43 & 0,54 & 0,43 & 0,32 & & & & & \\
Hs10 & 2,68 & 2,67 & 0,44 & 0,44 & 0,32 & 0,22 & 0,43 & 0,54 & 0,43 & & & & \\
Hs11 & 2,93 & 2,92 & 0,55 & 1,24 & 0,89 & 1,00 & 0,88 & 1,22 & 1,11 & 1,33 & & & \\
Hs12 & 3,18 & 3,17 & 0,77 & 1,47 & 1,12 & 1,23 & 1,11 & 1,45 & 1,34 & 1,23 & 0,21 & & \\
Hs13 & 3,47 & 3,45 & 1,00 & 1,47 & 1,12 & 1,23 & 1,11 & 1,22 & 1,11 & 1,23 & 0,43 & 0,65 & \\
Hs14 & 3,60 & 3,58 & 1,11 & 1,58 & 1,23 & 1,34 & 1,22 & 1,34 & 1,22 & 1,34 & 0,54 & 0,76 & 0,11 \\
\hline
\end{tabular}


Tabela 11: Resumo dos índices de diversidade molecular para a região do gene $C O$ I verificados nas amostras de $F$. varia (F.v. campus USP e amostras externas), F. trichocerata (F.t.) e F. doederleini (F.d.).

\begin{tabular}{|c|c|c|c|c|c|c|c|c|}
\hline \multirow[b]{3}{*}{ Div. Molecular } & \multicolumn{6}{|c|}{ Frieseomelitta varia } & \multirow[b]{3}{*}{$\begin{array}{c}\boldsymbol{F} . \boldsymbol{t} . \\
\mathrm{n}=33\end{array}$} & \multirow[b]{3}{*}{$\begin{array}{l}\boldsymbol{F} . \boldsymbol{d} . \\
\mathrm{n}=3\end{array}$} \\
\hline & \multirow[b]{2}{*}{$\begin{array}{c}\text { C. USP } \\
n=33\end{array}$} & \multicolumn{4}{|c|}{ Amostras externas ao campus USP } & \multirow[b]{2}{*}{$\begin{array}{c}\text { Total }\left(\boldsymbol{F} . \boldsymbol{v}_{\mathbf{.}}\right) \\
\mathrm{n}=69\end{array}$} & & \\
\hline & & $\begin{array}{c}\text { GO-MT-MG } \\
n=15 \\
\end{array}$ & $\begin{array}{c}\mathbf{S P} \\
\mathrm{n}=13\end{array}$ & $\begin{array}{l}\text { MT } \\
\mathrm{n}=2\end{array}$ & $\begin{array}{c}\text { MG } \\
n=6\end{array}$ & & & \\
\hline $\mathrm{N}^{\mathrm{o}}$. haplótipos & 3 & 5 & 3 & 2 & 1 & 9 & 3 & 2 \\
\hline $\mathrm{N}^{\mathrm{o}}$. sítios polimórficos & 7 & 13 & 5 & 12 & 0 & 19 & 12 & 2 \\
\hline$h$ & $0,475 \pm 0,085$ & $0,752 \pm 0,091$ & $0,294 \pm 0,155$ & $1,000 \pm 0,500$ & $0,0 \pm 0,0$ & $0,517 \pm 0,068$ & $0,577 \pm 0,044$ & $0,667 \pm 0,314$ \\
\hline$\pi$ & $0,005 \pm 0,003$ & $0,012 \pm 0,007$ & $0,002 \pm 0,002$ & $0,030 \pm 0,031$ & $0,0 \pm 0,0$ & $0,006749 \pm 0,004036$ & $0,006 \pm 0,003$ & $0,003 \pm 0,003$ \\
\hline$k$ & $1,890 \pm 1,106$ & $4,800 \pm 2,483$ & $1,026 \pm 0,002$ & $12,00 \pm 8,831$ & $0,0 \pm 0,0$ & $2,666 \pm 0,915$ & $2,303 \pm 1,297$ & $1,333 \pm 1,098$ \\
\hline $\mathrm{N}^{\mathrm{o}}$. transições & 6 & 8 & 3 & 7 & 0 & 13 & 7 & 1 \\
\hline$N^{o}$. transversões & 7 & 6 & 2 & 5 & 0 & 7 & 5 & 1 \\
\hline Transições/Transversões & 0,857 & 1,333 & 1,500 & 1,400 & 0,000 & 1,857 & 1,400 & 1,000 \\
\hline$\% \mathrm{~A}+\mathrm{T}$ & 77,7 & 77,6 & 77,7 & 77,1 & 77,7 & 77,68 & 77,3 & 78,2 \\
\hline $\mathrm{N}^{\mathrm{o}}$. indels & 0 & 0 & 0 & 0 & 0 & 0 & 0 & 0 \\
\hline
\end{tabular}

$h$ : Diversidade haplotípica; $\pi$ : Diversidade nucleotídica; $k$ : Número médio de diferenças nucleotídicas entre os haplótipos encontrados 


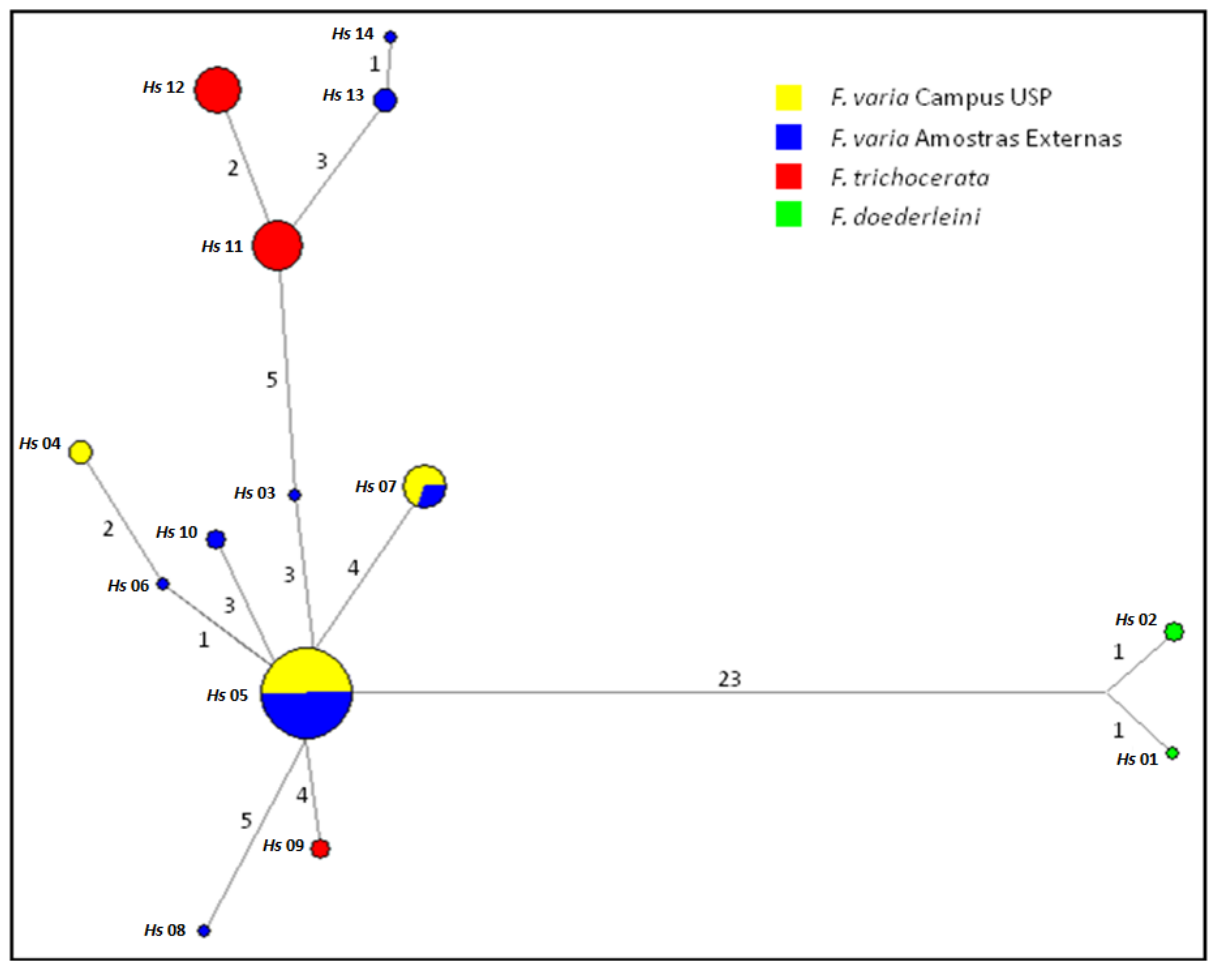

Figura 17: Rede de inter-relações entre os 14 haplótipos obtidos pelo seqüenciamento de um trecho do gene mitocondrial $C O \mathrm{I}$ para as espécies $F$. varia, $F$. trichocerata e $F$. doederleini. Os números próximos aos ramos indicam o número de passos mutacionais.

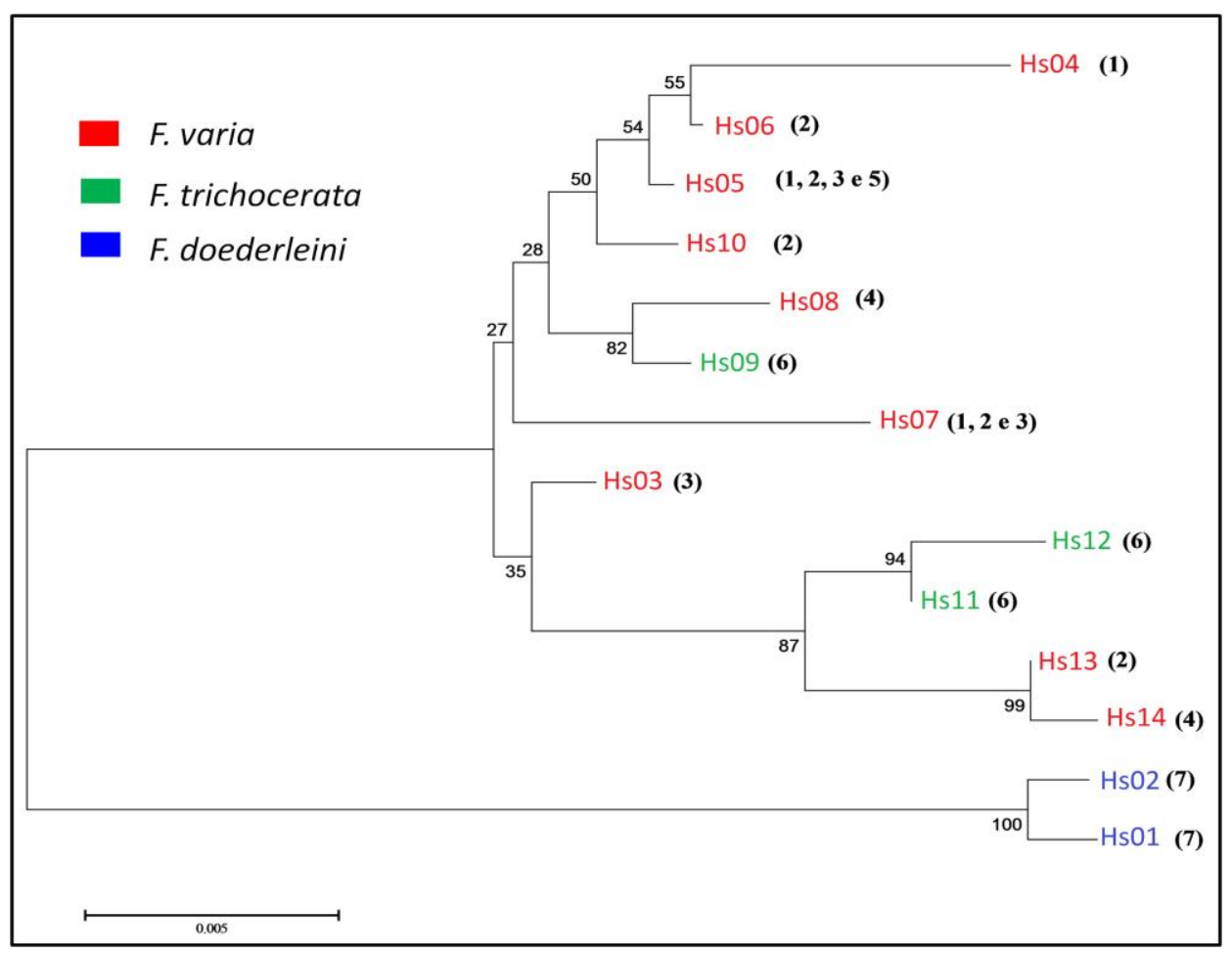

Figura 18: Cladograma mostrando as relações de distância entre os 14 haplótipos do gene COI. Os números entre parênteses indicam os grupos em que os haplótipos estão presentes - 1 : Campus USP; 2: GO-MT-MG; 3: SP; 4: MT; 5: MG; 6: F. trichocerata; 7: F. doederleini. 
As estimativas de divergência evolutiva entre os grupos amostrais, representadas pela média do número de substituições por sítio de cada população variaram de 0,001 a 0,073 (Tabela 12). Dentro de cada grupo a média de substituições por sítio variou de 0,000 a 0,031 .

Tabela 12: Estimativas de divergência de sequência (\%) inter e intra-amostral para as espécies $F$. varia, F. trichocerata $(F . t$.) e $F$. doederleini $(F . d$.$) .$

\begin{tabular}{|c|c|c|c|c|c|c|c|c|}
\hline \multirow{10}{*}{ F. varia } & & \multicolumn{5}{|c|}{ F. varia } & \multirow[b]{3}{*}{ F.t. } & \\
\hline & & \multirow[b]{2}{*}{ C. USP } & \multicolumn{4}{|c|}{ Amostras externas ao campus USP } & & \\
\hline & & & GO-MT-MG & SP & MT & MG & & F. $d$. \\
\hline & GO-MT-MG & 0,90 & & & & & & \\
\hline & SP & 0,40 & 0,80 & & & & & \\
\hline & MT & 2,10 & 2,00 & 2,10 & & & & \\
\hline & MG & 0,30 & 0,80 & 0,10 & 2,10 & & & \\
\hline & F.t. & 2,30 & 2,10 & 2,20 & 2,30 & 2,20 & & \\
\hline & F. $d$. & 6,40 & 6,60 & 6,30 & 7,30 & 6,40 & 6,80 & \\
\hline & Intra-amostral & 0,005 & 0,012 & $\mathbf{0 , 0 0 3}$ & $\mathbf{0 , 0 3 1}$ & 0,000 & 0,006 & 0,003 \\
\hline
\end{tabular}

Com os valores de divergência de sequência foi construída uma árvore de distância também baseada no método Neighbor-Joining (Tamura et al., 2007) (Figura 19). Pode-se observar na árvore que há o agrupamento em um clado formado pelas amostras de $F$. varia da população MT e as amostras de $F$. trichocerata.

Os valores de $F$ st calculados para cada par de grupos amostrais e apresentados na Tabela 12 indicam ausência de estruturação entre SP e MT (-0,03294), assim como entre SP e campus USP (-0,00893). Já para as amostras MG os valores de $F$ st indicam forte estruturação em relação aos outros grupos estudados, tendo como exceção apenas GO-MT-MG (Tabela 13). 


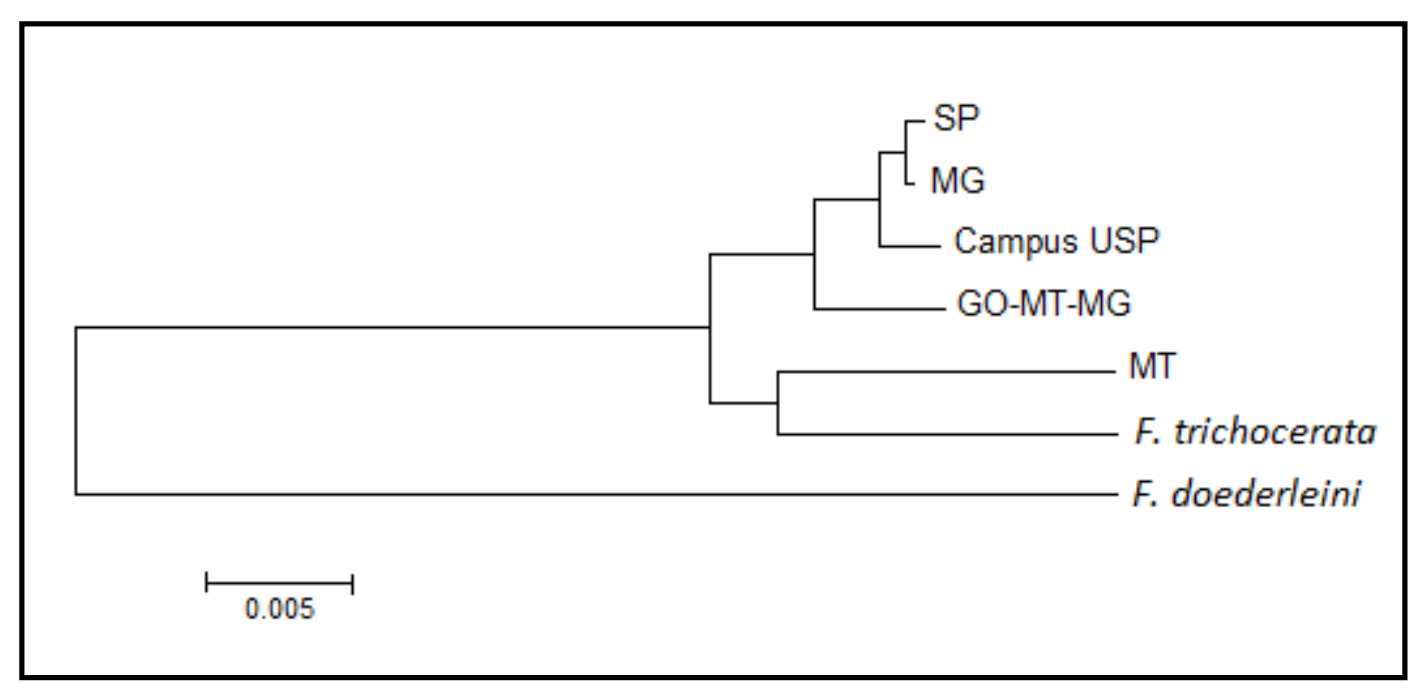

Figura 19: Cladograma mostrando as relações de distância genética entre os cinco grupos de amostras de $F$. varia (campus USP e amostras externas) e também das amostras de $F$. trichocerata e $F$. doederleini.

Tabela 13: Valores de $F$ st (abaixo da diagonal) e de $P$ (acima da diagonal) entre pares de grupos de $F$. varia estudados.

\begin{tabular}{c|ccccc}
\hline \multicolumn{1}{c}{} & C. USP & GO-MT-MG & SP & MT & MG \\
\cline { 2 - 6 } C. USP & - & 0,03586 & $0,42085^{*}$ & $0,37917^{*}$ & 0,00228 \\
GO-MT-MG & 0,10205 & - & $0,10039^{*}$ & $0,12989^{*}$ & $0,06435^{*}$ \\
SP & $-0,00893$ & 0,09153 & - & $0,77448^{*}$ & 0,00911 \\
MT & 0,02608 & 0,08943 & $-0,03294$ & - & 0,03515 \\
MG & 0,63210 & 0,15888 & 0,68104 & 0,68243 & - \\
\hline
\end{tabular}

* $\mathrm{P}>0,05$ - Estatisticamente não diferente de zero

Os valores de $P$ obtidos pelo teste exato de diferenciação populacional revelaram que as amostras do campus USP estão diferenciadas apenas das amostras MG e GO-MT-MG $(P<0,05)$. Esta última está diferenciada de MG, que por sua vez, está diferenciada das amostras de SP e MT $(P<0,05)$ (Tabela 14). Outro dado interessante foi que as amostras do campus USP não estão diferenciadas de MT, mesmo a uma distância de 1500 quilômetros. 
Tabela 14: Valores de $P$ obtidos através do teste exato de diferenciação populacional baseado nas frequências haplotípicas de cada população de $F$. varia. Os valores entre parênteses representam os erros padrão de cada estimativa de $P$.

\begin{tabular}{c|cccc}
\hline \multicolumn{1}{c}{} & C. USP & GO-MT-MG & SP & MT \\
\cline { 2 - 5 } GO-MT-MG & $0,00609_{(0,0014)}$ & & & \\
SP & $0,18730_{(0,0040)}$ & $0,11028_{(0,0022)}$ & & \\
MT & $0,44049_{(0,0034)}$ & $0,47101_{(0,0051)}$ & $1,00000(0,0000)$ & \\
MG & $0,00122_{(0,0002)}$ & $0,03151_{(0,0024)}$ & $0,05214(0,0026)$ & $0,03552(0,0007)$ \\
\hline
\end{tabular}

A Análise de Variância Molecular (AMOVA) revelou que a maior parte da diversidade haplotípica está distribuída entre os grupos amostrais, e não dentro dos mesmos (Tabela 15).

Tabela 15: Resultados da Análise de Variância Molecular (AMOVA) das amostras de F. varia.

\begin{tabular}{c|c|c|c}
\hline $\begin{array}{c}\text { Componente da } \\
\text { variância }\end{array}$ & \% do total & Variância & $\boldsymbol{\Phi}$ \\
\hline Interpopulacional & 68,67 & 2,58815 & 0,68669 \\
Intrapopulacional & 31,33 & 1,18087 & \\
\hline
\end{tabular}

$\Phi$ : Índice de Fixação; Numero de permutações: 1023 


\subsection{Microssatélites}

A partir da biblioteca enriquecida em microssatélites para $F$. varia, 78 clones foram sequenciados, sendo que 54 apresentaram sequências repetitivas (Figura 20). Doze dos 18 locos isolados foram padronizados quanto à amplificação via PCR e foram testados em 19 indivíduos de diferentes locais. Os resultados obtidos nesta triagem inicial dos locos se encontram sumarizados na Tabela 16.

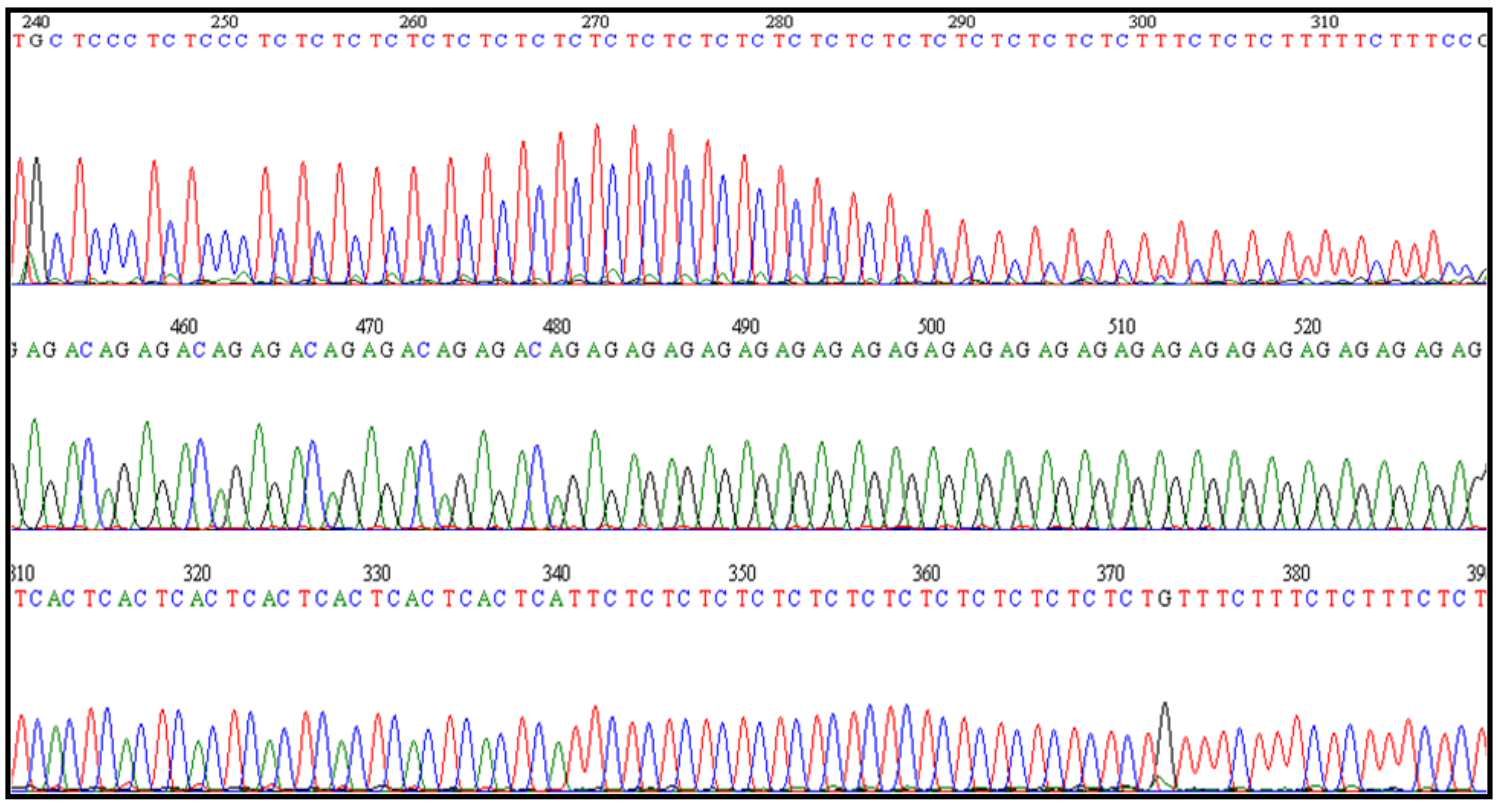

Figura 20: Eletroferogramas exemplificando repetições do tipo microssatélite obtidas a partir do sequenciamento de clones da biblioteca genômica construída para F. varia.

Dos 12 locos padronizados, cinco foram escolhidos para o prosseguimento desse trabalho, sendo todos polimórficos segundo os critérios de $95 \%$ e $99 \%$. O número de alelos variou de 2 a 17, sendo que o número médio de alelos por loco variou de 2,6 a 14,4 (Tabela 17). As taxas de heterozigose encontradas para as amostras de $F$. varia, $F$. trichocerata e $F$. doederleini são apresentadas na tabela 18. A Figura 21 mostra exemplos de alguns alelos encontrados. A distribuição dos alelos para cada loco em 
cada grupo amostral, bem como suas frequências são mostrados na Tabela 31 (Apêndice $3)$.

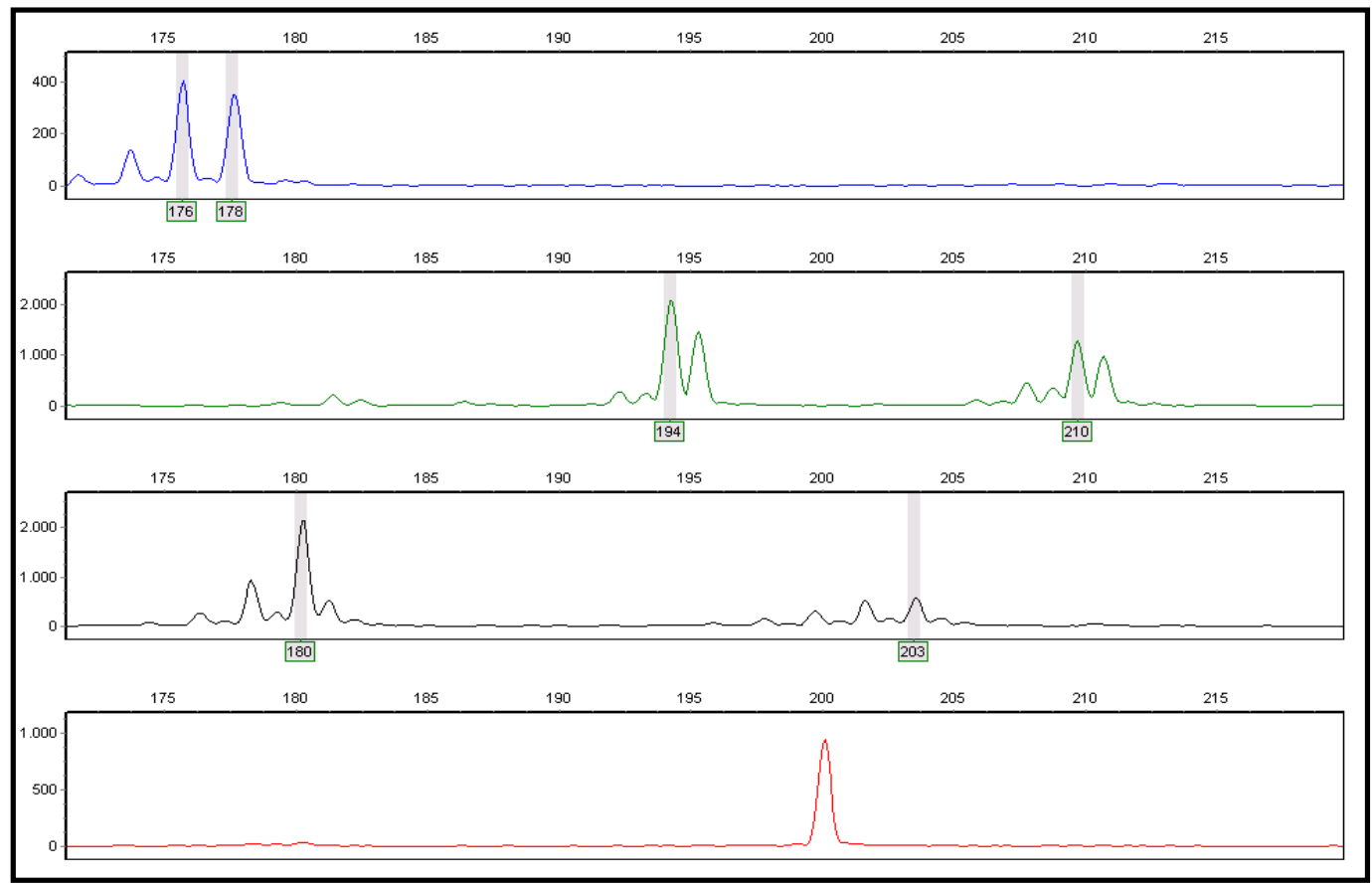

Figura 21: Interface do sotware GeneMarker v.1.85 mostrando exemplos de alelos encontrados nas triagens populacionais. 
Tabela 16: Resumo das características dos 12 locos microssatélites isolados de $F$. varia e dados gerais após triagem de 19 indivíduos de várias localidades do país. Motivo da repetição, sequência dos primers, temperatura de hibridação (Th), número de alelos encontrados (k), variação de tamanho observada, taxa de heterozigose observada $(H o)$ e esperada $(H e)$ são apresentados.

\begin{tabular}{|c|c|c|c|c|c|c|c|}
\hline Loco & Motivo de repetição & Sequência do primer (5'- 3') & Th $\left({ }^{\circ} \mathrm{C}\right)$ & $\mathbf{k}$ & $\begin{array}{l}\text { Tamanho } \\
\text { observado }\end{array}$ & $\boldsymbol{H}_{\boldsymbol{o}}$ & $\boldsymbol{H}_{e}$ \\
\hline Friv1 & $(\mathrm{GA})_{14}$ & $\begin{array}{l}\text { F: CACACGCCTAGCCGAATTAC } \\
\text { R: GGGGAACATCTCTTGGTTCA }\end{array}$ & 64 & 13 & $210-236$ & 0,67 & 0,85 \\
\hline Friv2 & $(\mathrm{GA})_{10}$ & $\begin{array}{l}\text { F: GACGAATTAATCAGTCCTGGAG } \\
\text { R: GCGAGACGAGCCTCTGTT }\end{array}$ & 56 & 6 & $202-220$ & 0,12 & 0,58 \\
\hline Friv4 & $(\mathrm{TC})_{8}$ & $\begin{array}{l}\text { F: CGATGACACGAGCATTGACT } \\
\text { R: TCCGTCATGAATGCCAATAG }\end{array}$ & 60 & 1 & 135 & - & - \\
\hline Friv5 & $(\mathrm{AG})_{11}$ & $\begin{array}{l}\text { F: TAGACGTAGCCAGCGAAG } \\
\text { R: TCGATCCGTCTTCTTGGTAA }\end{array}$ & 60 & 2 & $138-140$ & 0,15 & 0,14 \\
\hline Friv9 & $(\mathrm{TCAC})_{7} \mathrm{TCAT}(\mathrm{TC})_{15} \mathrm{TG}(\mathrm{TTTC})_{2}$ & $\begin{array}{l}\text { F: GTCGAGACGAACTTGGACGA } \\
\text { R: CGCCGCTAGTTCCCATATC }\end{array}$ & 57,5 & 8 & $198-224$ & 0,39 & 0,77 \\
\hline Friv10 & $\mathrm{TT}(\mathrm{TC})_{16}$ & $\begin{array}{l}\text { F: GGAACGAATCGATCTGCATTA } \\
\text { R: TATCGATCCAGCGATCCACT }\end{array}$ & 63 & 7 & $276-302$ & 0,50 & 0,77 \\
\hline Friv11 & $(\mathrm{GT})_{3} \mathrm{GC}(\mathrm{GT})_{10}$ & $\begin{array}{l}\text { F:AGAACGAGATCTGCCACGAC } \\
\text { R:TCACGAATCCGCTGATACAC }\end{array}$ & 60 & 2 & $222-224$ & 1,00 & 0,50 \\
\hline Friv12 & $(\mathrm{CA})_{17}$ & $\begin{array}{l}\text { F: TTGCCAATATCGGTCTAATCG } \\
\text { R: GACCGTTATCGTTGCAGAACT }\end{array}$ & 60 & 7 & $172-192$ & 0,78 & 0,76 \\
\hline Friv14 & $(\mathrm{AG})_{17}(\mathrm{G})_{3}(\mathrm{AG})$ & $\begin{array}{l}\text { F: TAATTCCACGTGTGCGTGAT } \\
\text { R: CAATTCAGGACGACCGTATG }\end{array}$ & 61 & 11 & $140-190$ & 0,11 & 0,83 \\
\hline Friv15 & $(\mathrm{AG})_{18}$ & $\begin{array}{l}\text { F:CGTACATACATCTGTCGAAGAACG } \\
\text { R: GCTGGCTCCTTCATTACGAG }\end{array}$ & 63 & 15 & $132-174$ & 0,58 & 0,89 \\
\hline Friv16 & $(\mathrm{AG})_{18}$ & $\begin{array}{l}\text { F: GCTTCTGCGTGTCAGCTC } \\
\text { R: GGCCCTCTCGTTTCCTTACT }\end{array}$ & 61 & 11 & $138-202$ & 0,42 & 0,87 \\
\hline Friv18 & $(\mathrm{AC})_{2}(\mathrm{GA})_{6}(\mathrm{AAAA})(\mathrm{GA})_{9}$ & $\begin{array}{l}\text { F: ATCCCACGGACGTGCTAC } \\
\text { R: CTCGTGTGTAGTCGGCTGAA }\end{array}$ & 60 & 16 & $170-204$ & 0,63 & 0,87 \\
\hline
\end{tabular}


Tabela 17: Número total e médio de alelos por loco em cada grupo de amostras de $F$. varia (campus USP e amostras externas), F. trichocerata e F. doederleini.

\begin{tabular}{|c|c|c|c|c|c|c|c|c|}
\hline \multirow[b]{3}{*}{ LOCO } & \multicolumn{6}{|c|}{ F. varia } & \multirow[b]{3}{*}{$\begin{array}{l}\text { F. } t . \\
\mathrm{n}=33\end{array}$} & \multirow[b]{3}{*}{$\begin{array}{l}\text { F.d. } \\
\mathrm{n}=3\end{array}$} \\
\hline & \multirow[b]{2}{*}{$\begin{array}{c}\text { C. USP } \\
\mathrm{n}=33\end{array}$} & \multicolumn{4}{|c|}{ Amostras externas ao campus USP } & \multirow[b]{2}{*}{$\begin{array}{l}\text { Total } \\
(\text { F.v. })\end{array}$} & & \\
\hline & & $\begin{array}{c}\text { GO-MT-MG } \\
\mathrm{n}=15\end{array}$ & $\begin{array}{c}\mathbf{S P} \\
\mathrm{n}=13\end{array}$ & $\begin{array}{l}\text { MT } \\
n=2\end{array}$ & $\begin{array}{l}\text { MG } \\
n=6\end{array}$ & & & \\
\hline Friv14 & 17 & 9 & 8 & 4 & 6 & 23 & 16 & 3 \\
\hline Friv15 & 6 & 7 & 4 & 4 & 4 & 14 & 15 & 3 \\
\hline Friv16 & 6 & 8 & 5 & 4 & 4 & 12 & 14 & 2 \\
\hline Friv18 & 13 & 14 & 8 & 4 & 7 & 22 & 15 & 2 \\
\hline Friv09 & 6 & 6 & 5 & 3 & 5 & 11 & 12 & 3 \\
\hline Total & 48 & 44 & 30 & 19 & 26 & 82 & 72 & 13 \\
\hline Média por loco & 9,6 & 8,8 & 6,0 & 3,8 & 5,2 & 16,4 & 14,4 & 2,6 \\
\hline
\end{tabular}

Tabela 18: Taxa de heterozigose esperada $(\mathrm{He})$ e observada $(\mathrm{Ho})$, segundo o Equilíbrio de Hardy-Weinberg, para os cinco locos de microssatélites para as amostras de $F$. varia, $F$. trichocerata (F.t.) e $F$. doederleini (F.d.). Heterozigose observada e esperada são também mostradas para cada grupo amostral e para cada loco.

\begin{tabular}{|c|c|c|c|c|c|c|c|c|c|}
\hline & & & $F . v c$ & & & & & & \\
\hline & & & Amostras ex & ernas a & campus & JSP & & & \\
\hline LOCO & & $\begin{array}{c}\text { C. USP } \\
\mathrm{n}=33\end{array}$ & 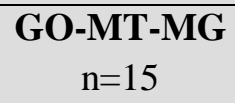 & $\begin{array}{c}\mathbf{S P} \\
\mathrm{n}=13\end{array}$ & $\begin{array}{l}\text { MT } \\
\mathrm{n}=2\end{array}$ & $\begin{array}{l}\text { MG } \\
\mathrm{n}=6\end{array}$ & $\begin{array}{c}\text { H.M.T } \\
\mathrm{n}=69\end{array}$ & $\begin{array}{l}\boldsymbol{F} . t . \\
\mathrm{n}=33\end{array}$ & $\begin{array}{l}\text { F.d. } \\
\mathrm{n}=3\end{array}$ \\
\hline & $\mathrm{Ho}$ & 0,788 & 0,533 & 0,769 & 0,000 & 1,000 & $\mathbf{0 , 6 1 8}$ & 0,900 & 0,3333 \\
\hline Friv14 & $\mathrm{He}$ & 0,877 & 0,727 & 0,805 & 1,000 & 0,778 & 0,837 & 0,888 & 0,6111 \\
\hline Eriv15 & Ho & 0,656 & 0,538 & 0,583 & 0,000 & 0,667 & 0,488 & 0,679 & 0,6667 \\
\hline Frivis & $\mathrm{He}$ & 0,781 & 0,698 & 0,549 & 1,000 & 0,625 & 0,730 & 0,874 & 0,6111 \\
\hline Friv16 & Ho & 0,786 & 0,800 & 0,333 & 0,000 & 0,167 & 0,417 & 0,867 & 0,0000 \\
\hline & $\mathrm{He}$ & 0,737 & 0,804 & 0,420 & 1,000 & 0,597 & 0,711 & 0,858 & 0,5000 \\
\hline & Ho & 0,625 & 0,933 & 0,833 & 0,000 & 0,833 & 0,644 & 0,833 & 0,6667 \\
\hline Frivl8 & $\mathrm{He}$ & 0,791 & 0,898 & 0,712 & 1,000 & 0,806 & 0,841 & 0,878 & 0,4444 \\
\hline & Ho & 0,594 & 0,333 & 0,385 & 1,000 & 0,833 & 0,629 & 0,833 & 0,6667 \\
\hline & $\mathrm{He}$ & 0,698 & 0,618 & 0,491 & 0,500 & 0,764 & 0,614 & 0,859 & 0,5000 \\
\hline Ho $\mathrm{m}$ & & 0,690 & 0,628 & 0,581 & 0,900 & 0,700 & 0,559 & 0,822 & 0,467 \\
\hline $\mathrm{He} \mathbf{m}$ & & 0,777 & 0,749 & 0,595 & 0,725 & 0,714 & 0,746 & 0,872 & 0,533 \\
\hline
\end{tabular}

H.M.T: Taxas médias de heterozigose observada e esperada total para $F$. varia. 
Baseado na distribuição genotípica entre as amostras coletadas, realizamos uma análise do tipo "assign" entre os indivíduos. Esta análise resultou no gráfico mostrado na Figura 22.

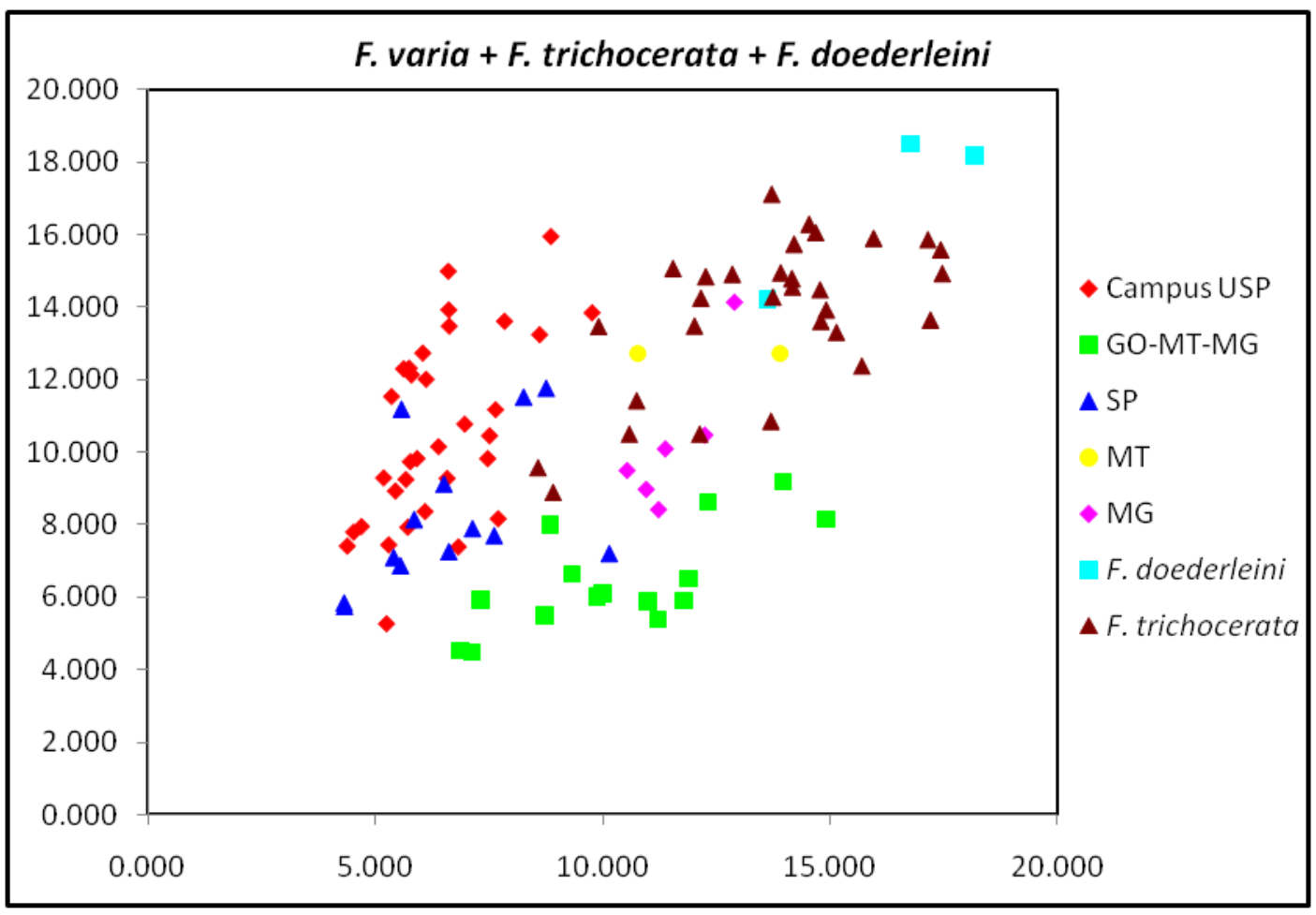

Figura 22: Gráfico de dispersão mostrando distribuição genotípica proveniente da análise de "assign" das amostras de F. varia, F. trichocerata e F. doederleini.

O gráfico mostra uma clara separação entre as amostras de $F$. varia do campus USP ( $\bullet$ ) e GO-MT-MG ( $\left.{ }^{*}\right)$. Entretanto, entre campus USP e SP ( ) não houve separação. Entre $F$. varia e $F$. trichocerata ( 4 ) houve uma grande área de sobreposição. Em contrapartida, entre $F$. varia e $F$. doederleini ( $\equiv$ ) houve uma notável separação, ocorrendo apenas um ponto em sobreposição com $F$. varia.

Para verificar se as amostras estavam em Equilíbrio de Hardy-Weinberg (EHW) realizamos testes exatos onde assumimos $\alpha=0,05$. A hipótese nula deste teste foi de "união aleatória dos gametas". Os resultados estão apresentados na Tabela 19. Houve desvio das premissas de Hardy-Weinberg em diversos grupos amostrais. Para o loco 
Friv15 foram três os que não estavam em panmixia: campus USP $(0,0231 \pm 0,0032)$, GO-MT-MG $(0,0235 \pm 0,0068)$ e F. trichocerata $(0,0013 \pm 0,0010)$. Para o loco Friv18 as populações foram as do campus USP $(0,0000 \pm 0,0000)$ e $F$. trichocerata $(0,0000 \pm$ 0,0000). Já para o loco Friv9 o único grupo que não estava em EHW foi GO-MT-MG $(0,0271 \pm 0,0044)$

Tabela 19: Valores de $P$ obtidos no teste exato de Equilíbrio de Hardy-Weinberg para cada loco e para cada grupo amostral de $F$. varia (campus USP e amostras externas), F. trichocerata (F.t.) e $F$. doederleini (F.d.) (colunas). Os números entre parênteses são os erros padrão.

\begin{tabular}{|c|c|c|c|c|c|c|c|c|c|c|}
\hline \multirow{3}{*}{$\begin{array}{l}\text { LOCO } \\
\text { Friv14 }\end{array}$} & \multicolumn{5}{|c|}{ Amostras de $F$. varia externas ao campus } & \multirow[b]{2}{*}{ F.t. } & \multirow[b]{2}{*}{ F.d. } & \multirow[b]{2}{*}{$\chi^{2}$} & \multirow[b]{2}{*}{ G.L. } & \multirow[b]{2}{*}{$\boldsymbol{P}$} \\
\hline & C. USP & GO-MT-MG & SP & MT & MG & & & & & \\
\hline & $\begin{array}{l}0,0522 \\
(0,0182)\end{array}$ & $\begin{array}{c}0,1242 \\
(0,0182)\end{array}$ & $\begin{array}{l}0,0743 \\
(0,0091)\end{array}$ & $\begin{array}{l}1,0000 \\
(0,0000)\end{array}$ & $\begin{array}{l}1,0000 \\
(0,0000)\end{array}$ & $\begin{array}{l}0,2098 \\
(0,0283)\end{array}$ & $\begin{array}{l}0,1971 \\
(0,0036)\end{array}$ & 21,648 & 14 & 0,086 \\
\hline Friv15 & $\begin{array}{c}0,0231 * \\
(0,0032)\end{array}$ & $\begin{array}{c}0,0235^{*} \\
(0,0068)\end{array}$ & $\begin{array}{c}0,6686 \\
(0,0080)\end{array}$ & $\begin{array}{l}1,0000 \\
(0,0000)\end{array}$ & $\begin{array}{l}0,4714 \\
(0,0068)\end{array}$ & $\begin{array}{c}0,0013 * \\
(0,0010)\end{array}$ & $\begin{array}{c}0,4826 \\
(0,0074)\end{array}$ & 32,108 & 14 & 0,004 \\
\hline Friv16 & $\begin{array}{c}0,9773 \\
(0,0022)\end{array}$ & $\begin{array}{c}0,8090 \\
(0,0123)\end{array}$ & $\begin{array}{c}0,2078 \\
(0,0118)\end{array}$ & $\begin{array}{l}1,0000 \\
(0,0000)\end{array}$ & $\begin{array}{l}0,0653 \\
(0,0026)\end{array}$ & $\begin{array}{c}0,6544 \\
(0,0329)\end{array}$ & $\begin{array}{c}0,3332 \\
(0,0018)\end{array}$ & 12,115 & 14 & 0,597 \\
\hline Friv18 & $\begin{array}{c}0,0000 * \\
(0,0000)\end{array}$ & $\begin{array}{l}0,5367 \\
(0,0338)\end{array}$ & $\begin{array}{l}0,2669 \\
(0,0227)\end{array}$ & $\begin{array}{l}1,0000 \\
(0,0000)\end{array}$ & $\begin{array}{c}0,6027 \\
(0,0084)\end{array}$ & $\begin{array}{c}0,0000 * \\
(0,0000)\end{array}$ & $\begin{array}{l}1,0000 \\
(0,0000)\end{array}$ & $\infty$ & 14 & $A S$ \\
\hline Friv9 & $\begin{array}{l}0,1562 \\
(0,0096)\end{array}$ & $\begin{array}{c}0,0271 * \\
(0,0044)\end{array}$ & $\begin{array}{r}0,1173 \\
(0,0072) \\
\end{array}$ & $\begin{array}{l}0,3339 \\
(0,0049)\end{array}$ & $\begin{array}{l}1,0000 \\
(0,0000)\end{array}$ & $\begin{array}{r}0,7159 \\
(0,0230)\end{array}$ & $\begin{array}{l}1,0000 \\
(0,0000)\end{array}$ & 18,077 & 14 & 0,203 \\
\hline$\chi^{2}$ & $\infty$ & 20,5552 & 16,0737 & 2,1941 & 7,9740 & $\infty$ & 6,9028 & & & \\
\hline g.l. & 10 & 10 & 10 & 10 & 10 & 10 & 10 & & & \\
\hline $\boldsymbol{P}$ & $A S$ & 0,024 & 0,097 & 0,994 & 0,631 & $A S$ & 0,734 & & & \\
\hline
\end{tabular}

Para verificar a possível causa dos desvios do equilíbrio de Hardy-Weinberg, realizamos um teste para verificar se havia excesso ou deficiência de heterozigotos (Teste "U”) na amostragem. O resultado foi positivo para deficiência de heterozigotos. De acordo com o teste "U" dos três grupos amostrais que desviaram do EHW, para o loco Friv15, dois apresentaram deficiência de heterozigotos $(P<0,05)$ : GO-MT-MG $(0,0403 \pm 0,0055)$ e $F$. trichocerata $(0,0000 \pm 0,0000)$. Há também a possibilidade de 
haver deficiência de heterozigotos nas amostras do campus USP $(0,0520 \pm 0,0042)$ visto que o valor de $P$ encontrado para este grupo amostral estava próximo do limiar de $\alpha=0,05$, e considerando o erro padrão de $P$ para menos, este valor ficaria abaixo desse limiar. Para os demais locos, todos os grupos que não estavam em EHW também apresentaram deficiência de heterozigotos segundo o teste " $U$ ". Entretanto este teste também detectou deficiência de heterozigotos para grupos que estavam em EHW [loco Friv14 - Campus USP $(0,0195 \pm 0,0102)$ e GO-MT-MG $(0,0303 \pm 0,0084)]$.Os valores de $P$ deste teste se encontram na Tabela 20.

Tabela 20: Valores de $P$ e erros padrão (entre parênteses) resultantes do teste "U" para verificação do desvio do equilíbrio de Hardy-Weinberg por deficiência de heterozigotos

\begin{tabular}{lcccccccc}
\hline \multicolumn{7}{c}{ Loco } & C. USP & \multicolumn{7}{c}{ Amostras de $F$. varia externas ao campus USP } & \multirow{2}{*}{ GO-MT-MG } & SP & MT & MG & F.t. & F.d. \\
\cline { 3 - 7 } Friv14 & $0,0195^{*}$ & $0,0303^{*}$ & 0,2201 & 1,0000 & 1,0000 & 0,0617 & 0,2029 \\
& $(0,0102)$ & $(0,0084)$ & $(0,0167)$ & $(0,0000)$ & $(0,0000)$ & $(0,0163)$ & $(0,0035)$ \\
Friv15 & $0,0520^{*}$ & $0,0403^{*}$ & 0,4717 & 1,0000 & 0,4899 & $0,0000^{*}$ & 0,3386 \\
& $(0,0042)$ & $(0,0055)$ & $(0,0083)$ & $(0,0000)$ & $(0,0079)$ & $(0,0000)$ & $(0,0078)$ \\
Friv16 & 0,6756 & 0,2402 & 0,0856 & 1,0000 & $0,0088^{*}$ & 0,1292 & 0,3344 \\
& $(0,0124)$ & $(0,0163)$ & $(0,0062)$ & $(0,0000)$ & $(0,0012)$ & $(0,0224)$ & $(0,0019)$ \\
Friv18 & $0,0000^{*}$ & 0,4491 & 0,9197 & 1,0000 & 0,5647 & $0,0420 *$ & 1,0000 \\
& $(0,0000)$ & $(0,0388)$ & $(0,0126)$ & $(0,0000)$ & $(0,0176)$ & $(0,0129)$ & $(0,0000)$ \\
Friv9 & 0,1411 & $0,0014 *$ & 0,1158 & 0,3333 & 0,6705 & 0,1504 & 1,0000 \\
& $(0,0103)$ & $(0,0008)$ & $(0,0072)$ & $(0,0054)$ & $(0,0092)$ & $(0,0201)$ & $(0,0000)$ \\
\hline$* P<0,05$ & & & & & & &
\end{tabular}

Também foram realizados testes exatos para verificar se os locos usados estavam em desequilíbrio de ligação, ou seja, se os locos não estavam segregando independentemente. A hipótese nula para este teste era: “os genótipos de um loco são independentes dos genótipos de outros locos". Desequilíbrio de ligação foi encontrado 
apenas entre os locos Friv18 e Friv9 $(P<0,05)$ nas amostras do campus USP. Os valores de $P$ provenientes destes testes estão listados na Tabela 21.

Tabela 21: Valores de $P$ e erros padrão (entre parênteses) provenientes do teste exato para verificação de desequilíbrio de ligação entre pares de locos microssatélites

\begin{tabular}{cccccccc}
\hline \multirow{2}{*}{ Loco } & \multicolumn{7}{c}{ Amostras de $F$. varia externas ao campus USP } \\
\cline { 3 - 6 } Friv14+Friv15 & C. USP & GO-MT-MG & SP & MT & MG & F.t. & F.d. \\
\cline { 2 - 6 } Friv14+Friv16 & 1,000 & 1,000 & 1,000 & - & - & 0,230 & - \\
Friv14+Friv18 & $(0,000)$ & $(0,000)$ & $(0,000)$ & - & - & $(0,039)$ & - \\
& 0,683 & 1,000 & 0,788 & - & - & 0,101 & - \\
Friv14+Friv9 & $(0,039)$ & $(0,000)$ & $(0,013)$ & - & - & $(0,029)$ & - \\
& 0,099 & 1,000 & 1,000 & - & - & 1,000 & - \\
Friv15+Friv16 & $(0,026)$ & $(0,000)$ & $(0,000)$ & - & - & $(0,000)$ & - \\
& 0,480 & 0,755 & 1,000 & - & - & 1,000 & - \\
Friv15+Friv18 & $(0,041)$ & $(0,026)$ & $(0,000)$ & - & - & $(0,000)$ & - \\
& 0,706 & 0,135 & 0,108 & - & - & 0,192 & - \\
Friv15+Friv9 & $(0,031)$ & $(0,024)$ & $(0,008)$ & - & - & $(0,038)$ & - \\
& 0,553 & 1,000 & 0,732 & - & - & 1,000 & - \\
Friv16+Friv18 & $(0,038)$ & $(0,000)$ & $(0,013)$ & - & - & $(0,000)$ & - \\
& 0,255 & 1,000 & 0,621 & - & - & 1,000 & - \\
Friv16+Friv9 & $(0,028)$ & $(0,000)$ & $(0,011)$ & - & - & $(0,000)$ & - \\
& 0,966 & 1,000 & 0,698 & - & - & 1,000 & - \\
Friv18+Friv9 & $(0,012)$ & $(0,000)$ & $(0,016)$ & - & - & $(0,000)$ & - \\
& 0,618 & 1,000 & 0,228 & - & - & 0,081 & - \\
& $(0,023)$ & $(0,000)$ & $(0,010)$ & - & - & $(0,025)$ & - \\
& $0,014 *$ & 1,000 & 0,122 & - & - & 0,429 & - \\
& $(0,007)$ & $(0,000)$ & $(0,008)$ & - & - & $(0,047)$ & - \\
\hline
\end{tabular}

*: $P<0,05 ;$-: Não Informativo

Testes para verificar desequilíbrio de ligação também foram realizados utilizando os dados alélicos de todas as populações em conjunto. Nesta análise nenhum loco estava em desequilíbrio de ligação $(P>0,05)$ como mostrado na Tabela 22. 
Tabela 22: Valores de $P$ provenientes do teste exato para verificação de desequilíbrio de ligação entre pares de locos microssatélites considerando todas as amostras em conjunto

\begin{tabular}{c|c|c|c}
\hline Pares de locos & $\chi^{\mathbf{2}}$ & G.L. & $\boldsymbol{P}$ \\
\hline Friv14+Friv15 & 2,94 & 8,00 & 0,94 \\
Friv14+Friv16 & 5,83 & 8,00 & 0,67 \\
Friv15+Friv16 & 12,46 & 8,00 & 0,13 \\
Friv14+Friv18 & 4,62 & 8,00 & 0,80 \\
Friv15+Friv18 & 1,81 & 8,00 & 0,99 \\
Friv16+Friv18 & 0,79 & 8,00 & 1,00 \\
Friv14+Friv9 & 2,03 & 8,00 & 0,98 \\
Friv15+Friv9 & 3,69 & 8,00 & 0,88 \\
Friv16+Friv9 & 8,95 & 8,00 & 0,35 \\
Friv18+Friv9 & 14,48 & 8,00 & 0,07 \\
\hline
\end{tabular}

G.L.: Graus de liberdade

Foram realizados também testes de diferenciação populacional baseados em $F$ st entre as amostras de $F$. varia. Os resultados destes testes se encontram na Tabela 23.

Os dados indicaram que há estruturação entre as amostras de $F$. varia, já que os valores de $F$ st foram maiores que zero. No entanto, essa estruturação é discreta, sendo a maior estruturação encontrada entre as amostras MG e SP.

Tabela 23: Valores de $F$ st para cada par de populações de $F$. varia considerando todos os locos em conjunto

\begin{tabular}{c|cccc}
\multicolumn{1}{c}{ GO-MT-MG } & C. USP & GO-MT-MG & SP & MT \\
\cline { 2 - 5 } SP & 0,0847 & & & \\
MT & 0,0568 & 0,1276 & & \\
MG & 0,0204 & 0,0350 & 0,1373 & \\
\hline
\end{tabular}

Também foram realizados testes de diferenciação populacional baseados na distribuição alélica e genotípica dos grupos amostrais. Estes testes tinham como hipótese nula que "a distribuição alélica e genotípica era a mesma entre as populações". Observando a Tabela 24 é possível ver que todos os grupos diferem quanto à 
distribuição alélica, já que todos valores de $P$ foram inferiores a 0,05 . Com relação à distribuição genotípica, pudemos observar que apenas as populações MT e MG não estão diferenciadas $(P>0,05)$ (Tabela 25).

Tabela 24: Teste de diferenciação populacional baseado na distribuição alélica para cada par de populações de $F$. varia analisando todos os locos em conjunto

\begin{tabular}{c|c|c|c}
\hline Pares de locos & $\chi^{2}$ & G.L. & $\boldsymbol{P}$ \\
\hline C.USP+GO-MT-MG & $\infty$ & 10 & $\mathrm{AS}^{*}$ \\
C.USP+SP & 40,24875 & 10 & $0,000015^{*}$ \\
C.USP+MT & $\infty$ & 10 & $\mathrm{AS}^{*}$ \\
C.USP+MG & $\infty$ & 10 & $\mathrm{AS}^{*}$ \\
GO-MT-MG+SP & $\infty$ & 10 & $\mathrm{AS}^{*}$ \\
GO-MT-MG+MT & 27,444459 & 10 & $0,002214^{*}$ \\
GO-MT-MG+MG & 39,373234 & 10 & $0,000022^{*}$ \\
SP+MT & 37,194479 & 10 & $0,000052^{*}$ \\
SP+MG & 54,985769 & 10 & $0,000000^{*}$ \\
MT+MG & 20,552149 & 10 & $0,024442^{*}$ \\
\hline
\end{tabular}

$\infty$ : Infinito; *: $\mathrm{P}<0,05$

Os testes visando a detecção de possíveis alelos nulos nos cinco locos analisados revelaram a presença destes apenas para o loco Friv18 $(\mathrm{P}>0,05)$ devido ao excesso de homozigotos.

Os valores de $F$ is encontrados na análise das amostras utilizando todos os locos em conjunto são mostrados na Tabela 26. 
Tabela 25: Teste de diferenciação populacional baseado na distribuição genotípica para cada par de populações de $F$. varia analisando todos os locos em conjunto

\begin{tabular}{c|c|c|c}
\hline Pares de locos & $\boldsymbol{\chi}^{\mathbf{2}}$ & G.L. & $\boldsymbol{P}$ \\
\hline C.USP+GO-MT-MG & $\infty$ & 10 & $\mathrm{AS}$ \\
C.USP+SP & 34,77360 & 10 & $0,000136^{*}$ \\
C.USP+MT & 36,075540 & 10 & $0,000082^{*}$ \\
C.USP+MG & $\infty$ & 10 & $\mathrm{AS} *$ \\
GO-MT-MG+SP & 50,600398 & 10 & $0,000000^{*}$ \\
GO-MT-MG+MT & 20,970406 & 10 & $0,021301 \star$ \\
GO-MT-MG+MG & 28,990127 & 10 & $0,001251 \star$ \\
SP+MT & 27,746129 & 10 & $0,001982^{\star}$ \\
SP+MG & 41,484950 & 10 & $0,000009 \star$ \\
MT+MG & 13,450910 & 08 & 0,097248 \\
\hline
\end{tabular}

Tabela 26: Valores de Fis para cada grupo de amostras.

\begin{tabular}{c|c}
\hline Grupo amostral & $\boldsymbol{F i s}$ \\
\hline Campus USP & 0,1593 \\
GO-MT-MG & 0,2956 \\
SP & $-0,0914$ \\
MT & $-0,2846$ \\
MG & $-0,0744$ \\
F. trichocerata & 0,1612 \\
F. doederleini & 0,6698 \\
\hline
\end{tabular}




\subsection{Análise morfométrica das asas}

Para esta análise as amostras foram agrupadas de acordo com seu local de coleta, totalizando 14. São eles: Ribeirão Preto (campus USP), Bonfim Paulista, São Simão, , Ribeirão Cascalheira, Nova Xavantina, Araguarí, Luiz Antônio, Paranaíta, Alta Floresta, Iporá, Goiânia, Sabará e Franca. Marechal Deodoro (F. doederleini) e Espigão do Oeste (F. trichocerata). Cabe ressaltar que as asas das amostras de Viçosa-MG não foram analisadas devido a impossibilidade de montagem das lâminas, pois as asas destes indivíduos estavam muito avariadas.

Através dos 11 pontos anatômicos marcados em cada asa, foram gerados 18 medidas de deformação relativas $(\mathrm{k}=2 \mathrm{n}-4$, onde " $\mathrm{k}$ " representa o número de deformações relativas e "n" o número de marcos anatômicos). Com essas medidas, as análises multivariadas geraram valores de distâncias quadradas de Mahalanobis, que representam as distâncias morfológicas entre os grupos analisados. Esses dados encontram-se sumarizados na Tabela 27. Com estes valores foi também construído um cladograma de distância morfológica entre os grupos estudados (Figura 23).

Testes de validação cruzada foram realizados. O objetivo deste teste é verificar a confiabilidade das análises. Ele é realizado dividindo-se o número de classificações corretas pelo número total de asas analisadas. O valor resultante desta análise representa a probabilidade de que um indivíduo qualquer retirado ao acaso da amostragem seja corretamente classificado dentro do seu respectivo grupo. Esta análise gerou um valor de $86,1 \%$ de acerto, ou seja, $86,1 \%$ das asas analisadas foram corretamente classificadas. 
Tabela 27: Distâncias quadradas de Mahalanobis (abaixo da diagonal) obtidas através das análises multivariadas das deformações relativas encontradas para $F$. varia, $F$. trichocerata (EO) e $F$. doederleini (MD) e valores de $P$ (acima da diagonal).

\begin{tabular}{|c|c|c|c|c|c|c|c|c|c|c|c|c|c|c|}
\hline & $\mathbf{R P}$ & BP & MD & RC & NX & $\mathbf{A R}$ & SS & PA & EO & $\mathbf{A F}$ & IP & GO & $\mathbf{A S}$ & FR \\
\hline $\mathbf{R P}$ & & 0,000 & $0,288^{*}$ & 0,000 & 0,000 & 0,000 & 0,000 & 0,000 & 0,000 & 0,000 & 0,000 & 0,000 & 0,000 & 0,000 \\
\hline BP & 17,954 & & $0,183^{*}$ & 0,000 & 0,000 & 0,000 & 0,000 & 0,000 & 0,000 & 0,000 & 0,000 & 0,000 & 0,000 & 0,000 \\
\hline MD & 153,764 & 135,043 & & 0,000 & 0,000 & 0,000 & 0,000 & 0,000 & 0,000 & 0,000 & 0,000 & 0,000 & 0,000 & 0,000 \\
\hline RC & 7,625 & 25,008 & 147,318 & & 0,000 & 0,002 & 0,000 & 0,000 & 0,000 & 0,000 & 0,000 & 0,000 & 0,000 & 0,000 \\
\hline $\mathbf{N X}$ & 10,266 & 28,175 & 164,653 & 7,173 & & 0,027 & 0,000 & 0,000 & 0,000 & 0,000 & 0,000 & 0,000 & 0,000 & 0,000 \\
\hline $\mathbf{A R}$ & 25,895 & 37,530 & 140,661 & 22,751 & 17,891 & & $0,089^{*}$ & 0,000 & 0,000 & 0,000 & 0,016 & 0,013 & 0,049 & 0,012 \\
\hline SS & 16,025 & 20,650 & 129,428 & 14,201 & 15,604 & 17,075 & & 0,000 & 0,000 & 0,000 & 0,000 & 0,000 & 0,000 & 0,000 \\
\hline PA & 27,852 & 63,265 & 221,055 & 36,218 & 47,041 & 75,578 & 61,060 & & 0,000 & 0,001 & 0,000 & 0,000 & 0,000 & 0,000 \\
\hline EO & 14,243 & 49,636 & 219,094 & 26,064 & 33,179 & 56,639 & 48,239 & 9,519 & & 0,000 & 0,000 & 0,000 & 0,000 & 0,000 \\
\hline $\mathbf{A F}$ & 20,842 & 54,271 & 195,732 & 24,239 & 30,499 & 53,365 & 40,248 & 12,843 & 11,692 & & 0,000 & 0,000 & 0,000 & 0,000 \\
\hline IP & 17,564 & 20,152 & 148,373 & 16,036 & 11,862 & 21,274 & 19,215 & 66,177 & 51,135 & 46,077 & & 0,000 & 0,000 & 0,000 \\
\hline GO & 9,862 & 21,993 & 148,975 & 7,382 & 6,091 & 18,763 & 14,518 & 46,278 & 32,966 & 31,010 & 9,637 & & 0,000 & 0,000 \\
\hline $\mathbf{A S}$ & 7,077 & 18,741 & 145,040 & 6,030 & 6,955 & 16,047 & 12,107 & 51,136 & 34,969 & 37,613 & 9,526 & 7,028 & & 0,000 \\
\hline FR & 9,631 & 11,578 & 149,267 & 13,611 & 11,627 & 18,733 & 7,806 & 54,927 & 38,625 & 40,471 & 11,397 & 11,415 & 8,609 & \\
\hline
\end{tabular}

*=P>0,05: Estatisticamente não significante. RP-Ribeirão Preto; BP-Bonfim Paulista; MD-Marechal Deodoro (F. doederleini); RC-Ribeirão Cascalheira; NX-Nova Xavantina; AR-Araguari; SS-São Simão; PA-Paranaíta; EO-Espigão do Oeste (F. trichocerata); AF-Alta Floresta; IP; Iporá; GO-Goiânia; AS-Sabará e FR-Franca 


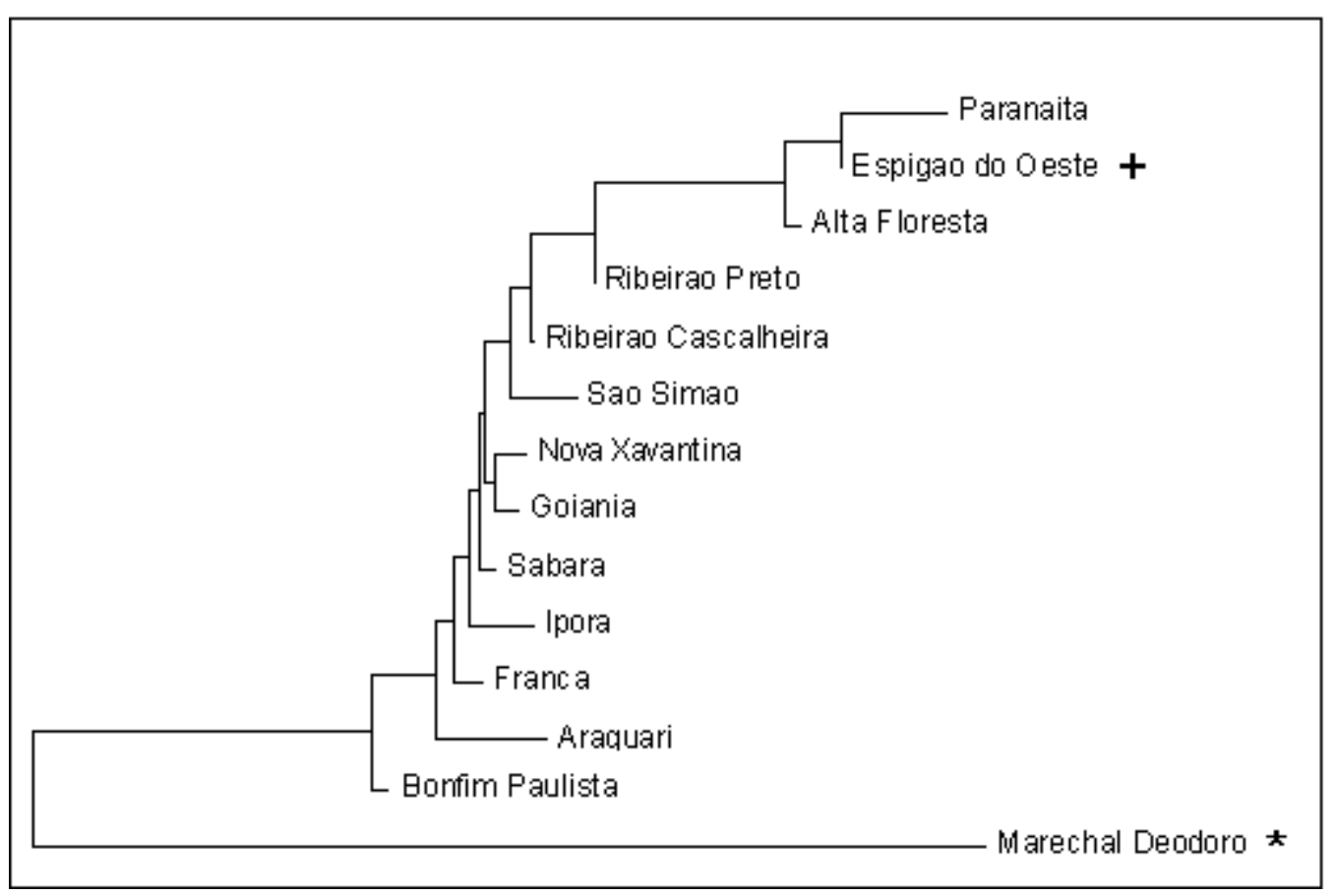

Figura 23: Dendograma obtido com os dados de Distância de Mahalanobis mostrando as relações morfológicas entre as amostras. +: Frieseomelitta trichocerata. *: Frieseomelitta doederleini. Demais localidades: Frieseomelitta varia.

As 18 medidas de deformação relativas obtidas foram analisadas também por Análise de Componente Principal (PCA - do inglês Principal Component Analysis). Os resultados desta análise geraram um gráfico que mostra as amostras de $F$. varia agrupadas juntamente com as amostras de $F$. trichocerata. As amostras de $F$. doederleini se apresentaram claramente separadas (Figura 24). Esses resultados demonstram a proximidade morfológica entre $F$. varia e $F$. trichocerata. Já $F$. doederleini (amostras de Marechal Deodoro) mostra uma separação nítida e consistente, corroborando as observações sobre a morfologia das três espécies (Oliveira, 2003).

Em uma tentativa de aumentar a resolução do gráfico da Figura 24, uma nova análise de componente principal foi realizada, porém excluindo-se as amostras de $F$. doederleini. Os resultados dessa re-análise reforçam ainda mais o agrupamento de $F$. varia e F. trichocerata, pois mesmo assim nota-se uma área de sobreposição dos pontos das duas espécies (Figura 25). 


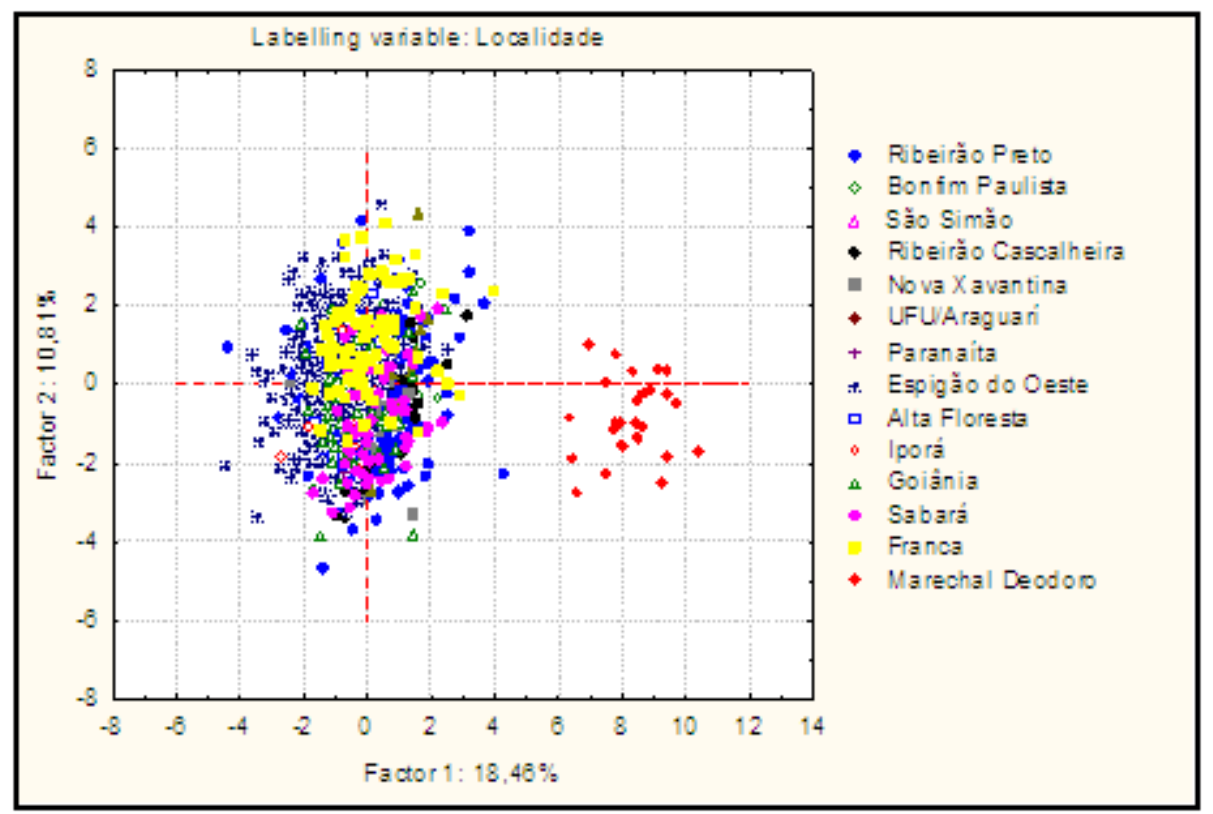

Figura 24: Gráfico de análise de componente principal mostrando o agrupamento das amostras de $F$. varia e $F$. trichocerata ( $*$ ); bem como a separação de $F$. doederleini ( $\bullet$ ).

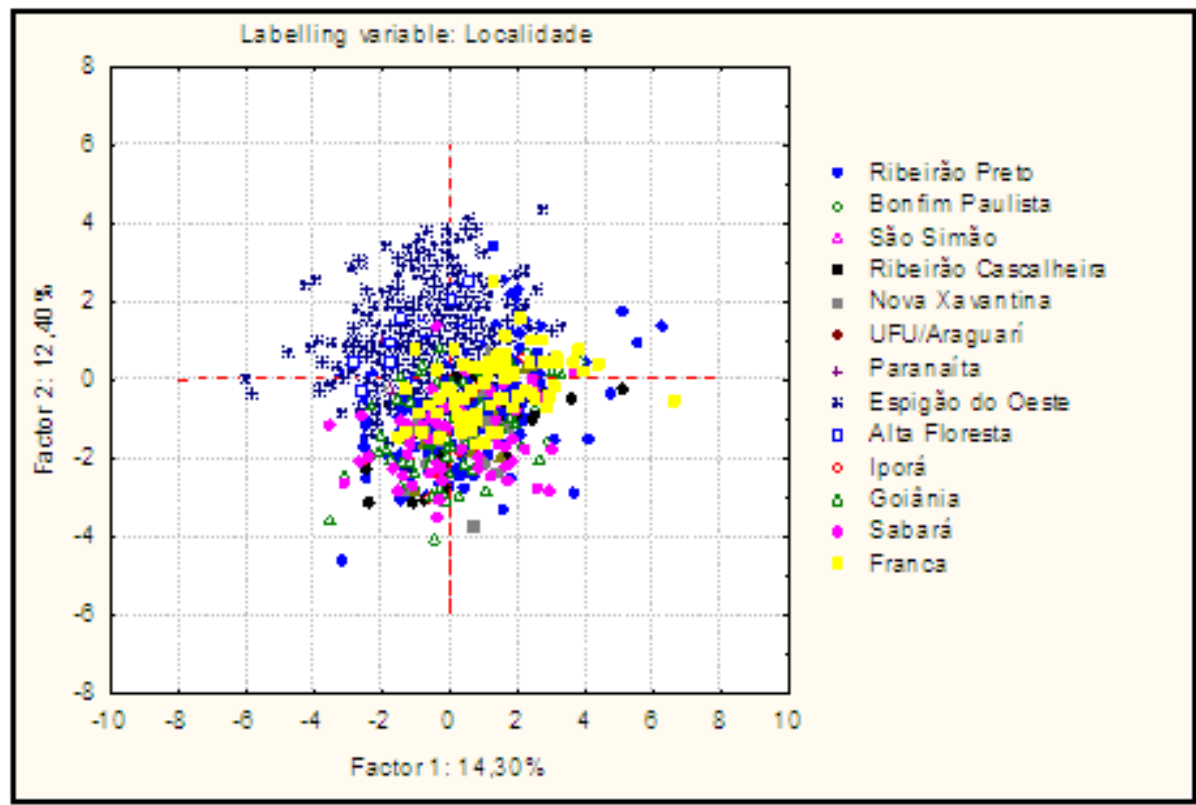

Figura 25: Gráfico de componente principal mostrando o agrupamento das amostras de $F$. varia e $F$. trichocerata (*) sem as amostras de $F$. doederleini. 


\section{Discussão}

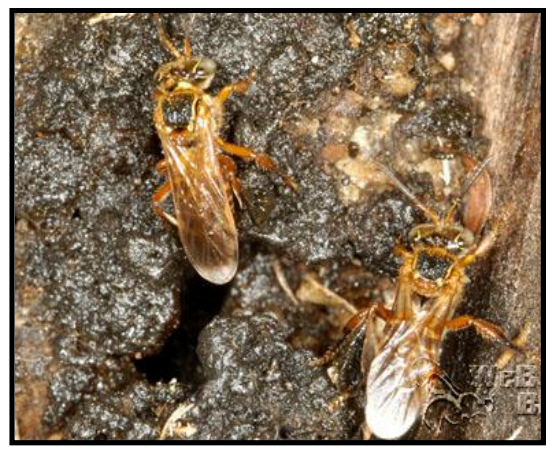




\subsection{O DNA mitocondrial e a morfologia}

Foram verificados por PCR-RFLP 21 haplótipos no total, sendo 16 para $F$. varia (campus USP e amostras externas), 4 para $F$. trichocerata e um para $F$. doederleini. Dos 16 haplótipos encontrados para $F$. varia, nove estavam presentes nas amostras do campus USP, sendo exclusivos à mesma. Para as amostras externas ao campus da USP (todas juntas) foram encontrados sete haplótipos, sendo dois deles compartilhados entre as amostras GO-MT-MG/SP, GO-MT-MG/MG e GO-MTMG/MT). Francisco e Arias (2010) analisaram o DNA mitocondrial de 70 amostras de Plebeia remota com o mesmo número de enzimas de restrição usado em nosso estudo (15) obtendo 15 haplótipos compostos. Estes autores encontraram forte estruturação genética entre os quatro locais de amostragem estudados e apenas dois haplótipos apresentaram sobreposição em dois locais. Brito e Arias (2010) amplificaram cinco regiões do DNAmt de Partamona helleri e as analisaram com seis enzimas de restrição, encontrando 10 haplótipos para 47 ninhos naturais distribuídos em 10 pontos de coleta. Assis (2010) encontrou apenas um haplótipo digerindo com 10 enzimas de restrição o DNAmt de 60 amostras de Nannotrigona testaceicornis provenientes de localidades do estado de São Paulo, inclusive do campus da USP em Ribeirão Preto, e também em Minas Gerais. Suzuki et al. (2010) encontraram 10 haplótipos compostos digerindo três regiões do DNAmt de 123 amostras de Euglossa fimbriata provenientes de seis fragmentos de floresta Atlântica do Paraná com 13 enzimas de restrição. Considerando que as coletas dos trabalhos mencionados foram realizadas em áreas naturais (em sua maioria), F. varia parece apresentar maior diversidade mitocondrial que as espécies citadas, visto que ela detém o maior número de haplótipos, e sendo que quase metade da amostragem é oriunda de um único local (campus USP, n=33). 
Os dados de PCR-RFLP obtidos em nosso estudo contradizem a maioria dos pressupostos de perda de variabilidade genética em pequenas populações, visto que o número de haplótipos, e por conseqüência a diversidade haplotípica, encontrados para a população do campus USP foram maiores do que para as amostras externas, indicando uma maior variabilidade no campus onde se esperava haver menor variabilidade devido aos diversos fatores explanados na introdução. É importante salientar também que não houve nenhum compartilhamento de haplótipos entre as amostras de F. varia do campus USP e as amostras externas ao mesmo, indicando isolamento destas amostras.

Já com o sequenciamento do gene COI encontramos no total 14 haplótipos, sendo 9 para $F$. varia ( 3 no campus USP e 6 nas amostras externas), três para $F$. trichocerata e dois para F. doederleini. No estudo de Assis (2010) foram encontrados, no total, cinco haplótipos mitocondriais através do sequenciamento do gene $C O I$ de Nannotrigona testaceicornis provenientes do campus da USP em Ribeirão Preto ( $\mathrm{n}=31$ ) e de áreas externas ao mesmo $(n=29)$, provenientes dos estados de SP e MG. Dos cinco haplótipos encontrados, três estavam presentes nas amostras do campus USP, sendo dois deles compartilhados com outras amostras: um com amostras de MG e SP e outro apenas com amostras de SP. Os outros dois haplótipos encontrados eram restritos às amostras de MG. Em comparação com nosso estudo, os valores de diversidade haplotípica $(h=0,264)$ e nucleotídica $(\pi=0,00386)$ encontrados por Assis $(2010)$ são baixos (Tabela 11).

Ao contrário dos dados de PCR-RFLP, o número de haplótipos para o COI (3) e a diversidade haplotípica $(0,517 \pm 0,068)$ provenientes da análise de sequências para as amostras do campus USP foram menores do que para as amostras externas (Tabelas 4, 6, 9 e 11). Ainda, os resultados do sequenciamento mostram que há compartilhamento de dois haplótipos (Hs05 e Hs07) entre as amostras do campus USP e as amostras 
externas (Tabela 9 e Figuras 15 e 16). O haplótipo Hs05 parece estar bem distribuído entre as amostras coletadas em áreas externas ao campus, já que ele está presente tanto em amostras coletadas em pontos mais próximos ao campus (Franca, São Simão, Bonfim Paulista e Ribeirão Preto) quanto em amostras coletadas em pontos bem distantes como Iporá-GO, Goiânia-GO, Araguari-MG, Viçosa-MG e Sabará-MG. Este haplótipo também foi o mais frequente em todos os grupos amostrais onde foi encontrado. O haplótipo Hs07 foi encontrado apenas nas amostras de Nova XavantinaMT e no campus. Esse fato pode ser interpretado como consequência de transporte de ninhos de Mato Grosso para o campus. Foi verificada também uma amostra Hs07 nas imediações do campus da USP, a poucos metros dos seus limites. Portanto, esse ninho muito provavelmente pode ser descendente, por enxameagem, de um ninho do campus, já que esse haplótipo, nessa área, apresenta uma freqüência de $21 \%$.

De fato, segundo o professor Ronaldo Zucchi (comunicação pessoal) da Faculdade de Filosofia Ciências e Letras de Ribeirão Preto (FFCLRP-USP), há algumas décadas houve o transporte de ninhos do Mato Grosso para o campus da USP em Ribeirão Preto. Porém, não se sabe exatamente o número, a exata procedência das colônias e nem a data precisa de quando elas foram introduzidas no campus. Segundo o professor Ademilson Espencer Egea Soares (comunicação pessoal), da FMRP-USP, a chegada desses ninhos teria ocorrido na década de 70 passada.

Como visto na Tabela 5, o menor valor de divergência de sequência de nucleotídeos $(d)$ encontrado entre os haplótipos verificados por PCR-RFLP foi entre Hr13 (presente nas amostras de GO-MT-MG e MT) e o haplótipo Hr17 (SP) (0,037\%). Em GO-MT-MG, as duas amostras que possuíam o haplótipo Hr13 eram provenientes de Nova Xavantina-MT. Já entre as amostras de MT o único indivíduo que possuía o haplótipo Hr13 era proveniente de Paranaíta-MT. O haplótipo Hr17, exclusivo das 
amostras de SP, foi verificado em apenas um ninho proveniente de Ribeirão Preto (área externa ao campus da USP), o mesmo que apresentou o haplótipo Hs07. Considerando também que não há a ocorrência dos haplótipos Hr13 e Hr17 em regiões compreendidas entre Mato Grosso e Ribeirão Preto, a pequena divergência de sequência entre estes dois haplótipos, a grande distância geográfica entre estes pontos de coleta (mais de 860 km) e os indícios de transporte de colônias, entre Mato Grosso e o campus da USP, a hipótese que levantamos é que o haplótipo $\operatorname{Hr} 17$ seria derivado do Hr13 e posteriormente introduzido em Ribeirão Preto, não tendo sido amostrado ou sido extinto em MT ou GO-MT-MG. Se este for o caso, observando a rede de haplótipos da Figura 14, é possível ver que o haplótipo Hr17 pode ter derivado tanto do Hr16 como do Hr13. No entanto, a maior probabilidade é de que o haplótipo Hr17 seja derivado do Hr13, pois entre estes dois há apenas um passo mutacional $(d=0,037 \%)$ contra cinco passos entre os haplótipos $\operatorname{Hr} 16$ e $\operatorname{Hr} 17(d=0,19 \%)$. Há uma única diferença entre os haplótipos Hr13 e Hr17, que consiste na ausência de uma banda em Hr13 devido ao ganho de um sítio de restrição Ase I na região COI, gerando duas bandas de menor peso molecular, o que caracteriza o haplótipo Hr17. No entanto, dados da literatura postulam que é mais provável a perda de um sítio de restrição por mutação do que o ganho do mesmo (Downling et al., 1996). Deste modo, há também a probabilidade do haplótipo Hr17 ser o mais antigo e ter dado origem ao Hr13. Se este for o caso, o haplótipo Hr17 teria sido introduzido em São Paulo, e novamente não amostrado no estado de Mato Grosso devido ao nosso baixo número amostral (2 indivíduos no grupo MT e 7 em GOMT-MG - Figuras 6 e 7) ou extinto.

Podemos ver que os resultados provenientes de PCR-RFLP e sequenciamento do COI são congruentes. As amostras de Nova Xavantina com o haplótipo Hr13 e a amostra com o haplótipo Hr17 em Ribeirão Preto apresentaram para o COI, o mesmo 
haplótipo (Hs07), corroborando a hipótese de transporte de ninhos. A única amostra que apresentou incongruência entre os resultados destas duas metodologias foi a amostra de Paranaíta-MT, que de acordo com o PCR-RFLP apresenta o mesmo haplótipo que as amostras de Nova Xavantina (Hr13), porém, de acordo com os dados de sequência do COI possui um haplótipo distinto (Hs08) das amostras de Nova Xavantina (Hs07). No entanto, a Tabela 10 mostra que a divergência de sequência entre os haplótipos Hs07 e Hs08 é baixa $(0,54 \%)$, indicando grande similaridade entre eles.

É possível que esta incongruência entre os resultados obtidos pelas duas metodologias seja explicada pelo maior refinamento que os dados de sequenciamento apresentam em relação aos de PCR-RFLP. As análises de sequências permitem analisar um grande número de bases, sendo todas potenciais marcas polimórficas. Em contraposição, com PCR-RFLP fica-se restrito apenas às mutações que ocorrem nos sítios de restrição das enzimas usadas, reduzindo-se substancialmente a quantidade de bases analisadas. É importante também mencionar que as regiões do gene COI amplificadas para PCR-RFLP e sequenciamento não eram as mesmas, por isso houve diferença no número de haplótipos encontrados na análise deste gene pelas duas metodologias. Os fatores explanados acima também explicam a presença de apenas um haplótipo para as amostras de F. doederleini através de PCR-RFLP (Hr18) e de dois através do sequenciamento do COI (Hs01 e Hs02).

A segunda menor divergência de sequência de nucleotídeos $(d=0,038 \%$ Tabela 5) foi encontrada entre os pares de haplótipos de PCR-RFLP Hr10/Hr16 e Hr14/Hr19. Estes dois últimos pertencentes a F. trichocerata. Os haplótipos Hr10 e Hr16 foram verificados nas amostras de $F$. varia coletadas em áreas externas ao campus USP, em diversas localidades. Porém eles parecem estar restritos à parte centro-leste do país, sendo encontrados em amostras dos estados de Goiás, Minas Gerais e São Paulo 
(Tabela 4). O haplótipo Hr14 foi verificado em uma única amostra de $F$. trichocerata coletada fora do grupo de 29 amostras do meliponário de Espigão do Oeste. Estas últimas apresentaram os três demais haplótipos descritos para essa espécie (Hr19, $\operatorname{Hr} 20$ e $\operatorname{Hr} 21)$.

Entretanto, considerando a herança materna e não recombinação do DNAmt, seria esperado apenas dois haplótipos entre as 29 amostras do meliponário de Espigão do Oeste, visto que elas foram geradas por divisões de dois ninhos ancestrais. $\mathrm{O}$ fato de ter sido encontrado um terceiro haplótipo para estas amostras pode ser explicado pela invasão de alguma caixa racional por um enxame vindo das redondezas. Segundo o meliponicultor que nos forneceu as amostras, a chácara onde está instalado seu meliponário é cercada de mata, e apesar de ele não ter constatado a invasão de nenhuma caixa, isto pode ter acontecido.

Assim como os dados de PCR-RFLP, as 29 amostras de F. trichocerata geradas por sucessivas divisões apresentaram três haplótipos através do sequenciamento do $\mathrm{COI}$ (Hs09, Hs11 e Hs12 - Tabela 9), sendo que a única amostra coletada fora do meliponário e que possuía um haplótipo distinto para PCR-RFLP, compartilhou um haplótipo de COI com as amostras do meliponário (Hs12).

Em relação aos dados de PCR-RFLP, quando comparamos as porcentagens de divergência de sequência de nucleotídeos entre pares de grupos amostrais (d) de $F$. varia, verificamos uma variação de 0,015 (SP/MG) a 0,295\% (campus USP/SP). No estudo de Francisco e Arias (2010) foram encontradas porcentagens de divergência que variaram de 0,6 a 3,86\% entre as populações de Plebeia remota estudadas. Brito (2005) encontrou valores deste mesmo parâmetro variando de 0,19 a 1,54\% em populações de Partamona helleri. Comparando com as porcentagens encontradas nesses estudos, os 
valores de divergência de sequência de nucleotídeos para $F$. varia são muito menores, indicando uma divergência recente entre esses haplótipos.

Os valores de "d" encontrados para os pares de grupos amostrais SP/MG e campus USP/SP contradizem o esperado, pois SP e MG estão muito mais distantes geograficamente que campus USP e SP, onde esperaríamos uma menor porcentagem de divergência de nucleotídeos, ou seja, uma maior similaridade devido à maior probabilidade de fluxo gênico.

A maior similaridade entre as amostras de SP e MG é confirmada pelos dados de sequências do COI. Neste caso, estes dois grupos amostrais também apresentaram a menor porcentagem de divergência de sequência entre as amostras de $F$. varia $(0,10 \%$ Tabela 12), corroborando os dados de PCR-RFLP. Entretanto, os dados do sequenciamento do $\mathrm{COI}$ apontam que as amostras do campus USP e SP, que foram as amostras mais divergentes segundo PCR-RFLP, apresentaram baixa divergência de sequência $(0,40 \%$-Tabela 11$)$.

Como se pode notar, em relação a PCR-RFLP as amostras do campus USP apresentaram maior variabilidade em relação às amostras externas. Ao contrário, com o sequenciamento do $\mathrm{COI}$ encontramos maior variabilidade nas amostras externas ao campus da USP. É possível que estas discordâncias entre os dados gerados por duas metodologias sejam devidas a diferenças nas taxas de acúmulo de mutações das regiões mitocondriais amplificadas. No caso de PCR-RFLP amplificamos cinco regiões distintas, que têm variadas taxas de substituição de nucleotídeos (Moritz et al., 1987). Já o gene sequenciado (COI) é frequentemente usado em estudos que têm como objetivo comparações interespecíficas (Hajibabaei et al.,2005; Hebert, et al., 2003), e tem sido empregado inclusive em abelhas (Sheffield, et al., 2009). Desse modo, em estudos que 
visam analisar a variação intraespecífica, a análise dessa região pode ser pouco informativa.

O fato de a meliponicultura ser uma fonte de entretenimento e renda para muitas pessoas torna a troca e o transporte de colônias uma prática muito comum. Entretanto esta ação não está restrita apenas aos meliponicultores, mas ela também ocorre em instituições de pesquisa que tratam da biologia de abelhas, como temos constatado. Devido a isto, ficamos impossibilitados de tirar conclusões mais acuradas sobre a colonização do campus da USP em Ribeirão Preto pela espécie $F$. varia, visto que aquela área parece não ter tido uma colonização totalmente natural. No entanto, podemos concluir que os atuais ninhos de $F$. varia do campus se originaram de pelo menos nove ninhos diferentes, já que encontramos nove linhagens mitocondriais distintas. Como as amostras do campus USP não compartilharam nenhum haplótipo com as amostras externas, tanto de pontos mais distantes como próximos geograficamente, podemos concluir que não há atualmente fluxo gênico via fêmea entre estas áreas. Fato este que pode ser explicado pela filopatria das rainhas. Esse comportamento leva a uma dispersão por enxameagem restrita, próxima do ninho mãe, pois o novo ninho depende de recursos alimentares e matéria prima que busca em seu ninho materno (Ross, 2001).

Quando observamos a divergência de sequência de nucleotídeos entre pares de grupos amostrais (d) (Tabela 7) das três espécies estudadas, verificamos que $F$. varia e F. trichocerata têm grande similaridade genética, visto que os valores de divergência variaram de 0,025 (campus USP/F. trichocerata) a 0,309\% (SP/F. trichocerata). Já entre $F$. varia e $F$. doederleini a divergência variou de 0,776 (MG/F. doederleini) a 1,012 (campus USP/F. dodederleini), implicando uma maior distância entre os haplótipos destas duas espécies. Estes resultados são coerentes com os encontrados 
através do sequenciamento do COI. De acordo com estes resultados as maiores porcentagens de divergência de sequência encontradas foram entre as espécies $F$. varia e $F$. doederleini, com valores de cerca de 6,3 a $7,3 \%$. Entretanto, entre $F$. varia e $F$. trichocerata as porcentagens de divergência de sequência se mantiveram menores, permanecendo em cerca de $2 \%$ (Tabela 12). É importante ressaltar que as amostras de F. varia coletadas no extremo norte do estado do Mato Grosso (amostras MT) apresentaram alta porcentagem de divergência de sequência nas comparações par a par com as outras localidades, e interessantemente o nível de divergência foi da mesma magnitude na comparação com a espécie $F$. trichocerata (valores acima de $2 \%$ - Tabela 12). Observando o cladograma construído com base nas porcentagens de divergência de sequências do $C O I$ apresentado na Figura 19, é possível ver que as amostras de $F$. varia de MT e as amostras de $F$. trichocerata formam um clado separado dos demais. Analisando ainda o cladograma construído com a divergência de sequência entre os haplótipos de COI (Figura 18) é possível ver que o haplótipo Hs09, pertencente a $F$. trichocerata, é agrupado com haplótipos de $F$. varia, indicando similaridade entre estes. Ainda, analisando os valores de bootstrap do cladograma da Figura 18, podemos ver que para os ramos que separam os haplótipos de $F$. trichocerata e $F$. varia este valor é baixo (28 e 35 respectivamente), indicando que possivelmente a variação entre estes haplótipos não é suficiente para separar estes haplótipos em clados distintos.

Hebert et al. (2003) estudaram aproximadamente $400 \mathrm{pb}$ do gene COI de 13.320 espécies pertencentes a 11 filos e verificaram que as porcentagens de divergência de sequência entre as mesmas variou de 0,0 a 53,7\%. Segundo estes autores $98 \%$ das espécies tiveram divergência de sequência acima de $2 \%$. Grande parte das espécies que tiveram divergências menores que $2 \%$ eram pertencentes ao filo dos cnidários, onde se sabe que as taxas de evolução do genoma mitocondrial são menores 
que as de outros filos (Shearer et al., 2002). Estes autores estimaram que entre as espécies de insetos a divergência de sequência do COI tipicamente varia entre 3 e $10 \%$. Berstch et al. (2005) verificaram que espécies crípticas de Bombus tinham divergência de sequência de cerca de 3\% para o gene COI.

Observando também as redes de inter-relações haplotípicas provenientes de PCR-RFLP e sequenciamento do COI (Figuras 14 e 17), é possível ver que todos os haplótipos de F. trichocerata (independentemente da metodologia) são derivados de haplótipos de F. varia. Ainda, o número de passos mutacionais que diferem estes haplótipos é baixo, comparado ao número de passos que diferenciam os haplótipos de $F$. varia e F. doederleini (58 para PCR-RFLP e 24 para o sequenciamento), com exceção apenas do haplótipo Hr21, que tem 22 passos diferenciando-o do haplótipo Hr15.

Os resultados genéticos aqui apresentados corroboram nossas observações a respeito da morfologia das espécies estudadas. F. varia e $F$. trichocerata apresentam morfologia muito semelhante tanto que as amostras de $F$. trichocerata só foram corretamente identificadas pela especialista do gênero. Consta no artigo de descrição de F. trichocerata que esta espécie é muito semelhante à $F$. varia (Moure, 1988). Ainda, Oliveira (2003) relata dificuldades do especialista em taxonomia Jesús Santiago Moure, descritor da espécie $F$. trichocerata, em classificar sem ambiguidades espécimes de $F$. varia e de $F$. trichocerata da região de Manaus-AM e Utiariti-MT. A diferenciação morfológica de $F$. varia e F. trichocerata é baseada em apenas um caractere, a saber, o comprimento dos pelos do escapo da antena. Em $F$. varia estes pelos são curtos e uniformemente distribuídos pelo escapo e em $F$. trichocerata são longos e não uniformemente distribuídos (Moure, 1988; Oliveira, 2003), como mostrado na Figura 24. Em contrapartida, entre $F$. varia e $F$. doederleini há notáveis diferenças morfológicas. Entre as que mais chamam a atenção estão o menor tamanho do corpo, a 
cor mais amarelada do tegumento e o menor tamanho da corbícula de $F$. doederleini (Oliveira, 2003).

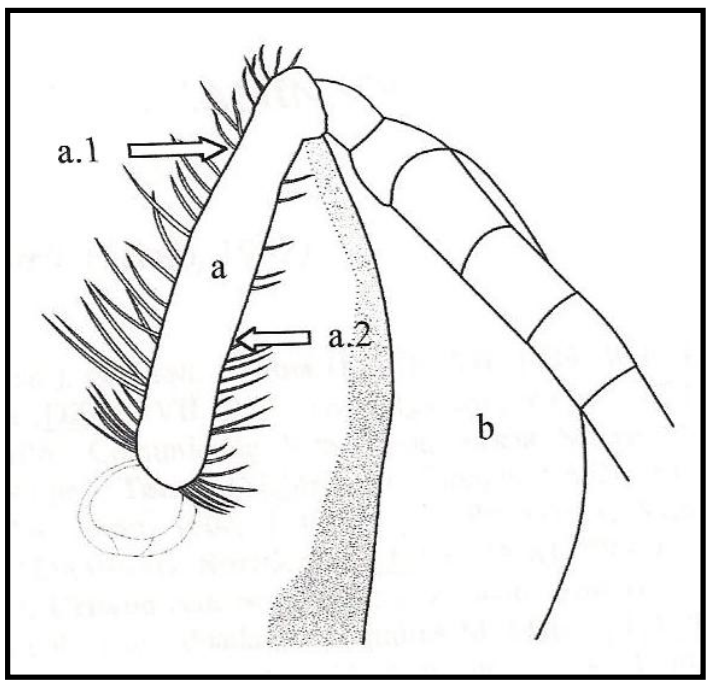

Figura 24: Esquema representando o escapo (a) da antena de uma operária de $F$. trichocerata e a distribuição dos pelos em seus bordos externo (a.1) e interno (a.2). b: olho. Fonte: Oliveira, (2003).

De fato, os dados gerados pela análise morfométrica das asas confirmam, com grandes taxas de acerto, os resultados das análises genéticas do DNAmt. Segundo Tiago M. Francoy (comunicação pessoal), o valor encontrado no teste de validação cruzada neste estudo $(86,1 \%)$ é bem alto considerando trabalhos com populações. Francoy (2007) obteve apenas 43,5\% de acerto neste mesmo teste analisando populações neotropicais de Apis mellifera. Em contraste, Mendes et al. (2007) obtiveram 77,6\% de acerto nos testes de validação cruzada estudando amostras de Nannotrigona testaceicornis de 20 ninhos da região de Uberlândia-MG.

Observando os valores de distância quadrada de Mahalanobis apresentados na Tabela 27, claramente podemos notar que os valores deste parâmetro entre as amostras de $F$. varia e $F$. doederleini (MD) são muito maiores que os encontrados entre $F$. varia e F. trichocerata. Esta maior distância morfológica entre $F$. varia e $F$. doederleini em 
relação a $F$. varia e $F$. trichocerata pode ser melhor visualizada através da média dos valores de distância de Mahalanobis entre os pares de localidades estudadas e também pelo cladograma gerado utilizando estes mesmos valores (Figura 23). Entre F. varia e $F$. trichocerata foi encontrada a média de 33,664 e entre $F$. varia e $F$. doederleini a média foi de 158,262. O cladograma da Figura 23 mostra a clara separação das amostras de $F$. doederleini, formando um clado irmão das amostras de $F$. varia. Ao contrário, as amostras de $F$. trichocerata juntamente com $F$. varia compõem um mesmo clado. É importante mencionar que as amostras coletadas no norte do estado do Mato Grosso (amostras MT) são morfologicamente próximas de $F$. trichocerata, corroborando os dados genéticos de divergência de sequência do $C O I$ que mostram que as porcentagens encontradas entre $F$. varia e $F$. trichocerata são similares às encontradas entre as amostras de $F$. varia de outras localidades e $F$. varia de MT (cerca de 2\%). Dado este que também pode ser visualizado no cladograma da Figura 19, que mostra o agrupamento das amostras MT com $F$. trichocerata em um mesmo clado.

Desta forma, considerando os resultados provenientes das análises genéticas de PCR-RFLP e sequenciamento do COI e também os resultados das análises de morfometria geométrica das asas das espécies estudadas, nós postulamos que $F$. trichocerata não deve ser considerada como uma espécie distinta, mas sim como um ecótipo de $F$. varia, do qual também fariam parte as amostras coletadas no norte de MT.

A hipótese de que $F$. trichocerata e as amostras de MT serem consideradas como um ecótipo, ou seja, uma variação geográfica de $F$. varia é reforçada quando observamos o mapa dos biomas brasileiros (Figura 25) e notamos que estas amostras foram coletadas em áreas do bioma da Amazônia. Em contraste, todas as outras amostras de $F$. varia foram coletadas em regiões de cerrado, à exceção das amostras de Sabará-MG. 


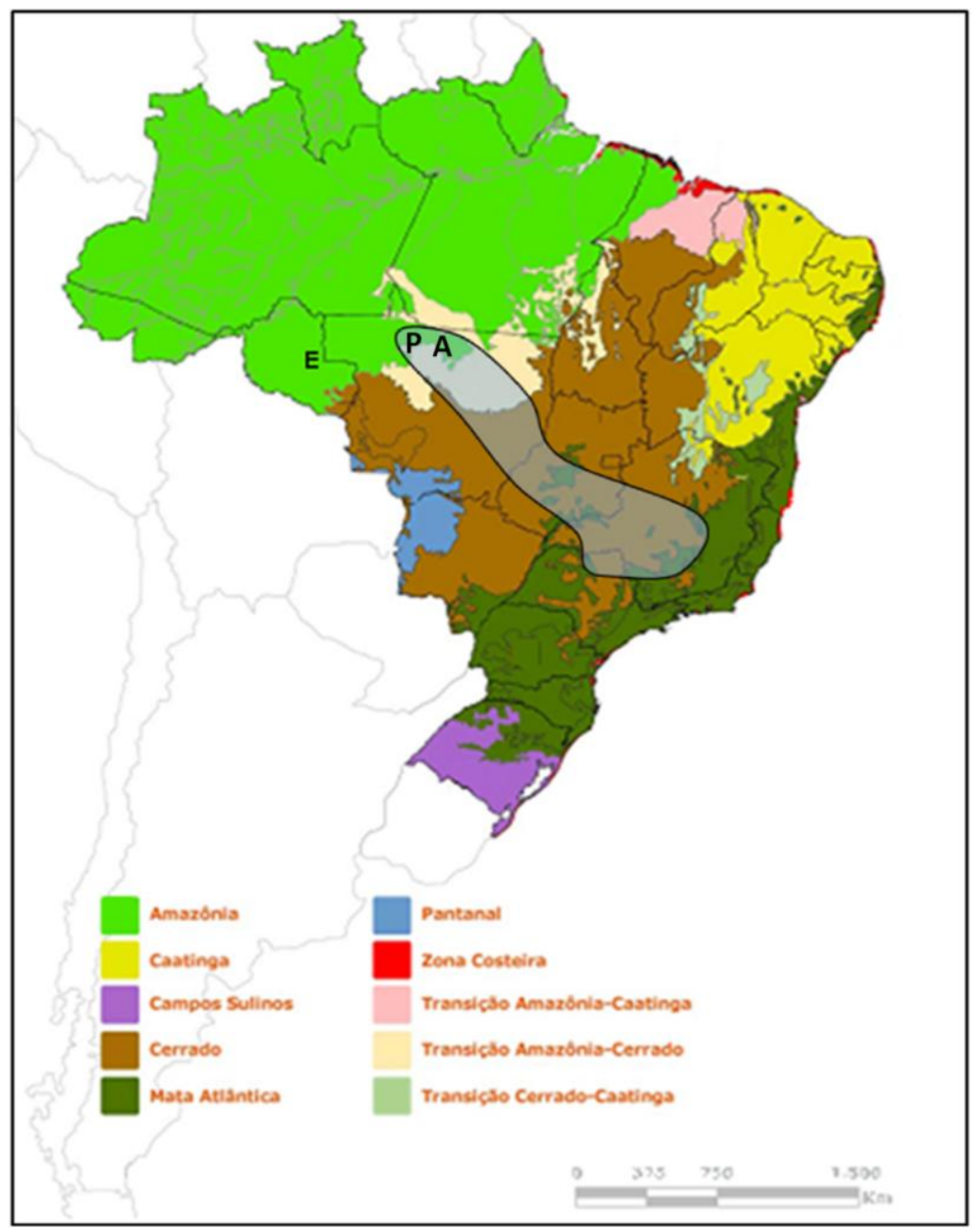

Figura 25: Mapa dos biomas brasileiros mostrando a localização das cidades de Espigão do Oeste-RO (E), local de coleta das amostras de F. trichocerata, Paranaíta-MT (P) e Alta Floresta-MT (A); e a área de abrangência de todas as coletas de $F$. varia (área azul translúcida). Adaptado de WWF Brasil (http://www.wwf.org.br/informacoes/questoes_ambientais/biomas)

Entretanto, para a confirmação desta hipótese seria necessária uma melhor amostragem tanto de $F$. varia quanto de $F$. trichocerata, que abrangesse toda a distribuição geográfica para avaliar qual o status genético e morfológico destas espécies.

Quezada-Euán et al. (2007) encontraram resultados opostos em seu estudo utilizando também marcadores genéticos (microssatélites e sequências do gene $C O I$ ) e morfológicos na análise de populações de Melipona beecheii provenientes da península 
Yucatânica e de Costa Rica, que são os extremos de distribuição desta espécie. Neste estudo encontraram significativa estruturação genética entre os pontos coletados, com divergência de sequência do gene $C O \mathrm{I}$ em torno de 1,2\%. A análise dos onze caracteres morfológicos revelou que havia significativas diferenças entre as amostras da península Yucatânica e da Costa Rica. Porém os autores argumentam não ser ainda possível determinar se as amostras provenientes destes dois pontos de coleta constituem espécies distintas ou somente de variação intraespecífica (ecótipos distintos) devido às características biológicas da espécie. 


\subsection{O DNA nuclear}

Os cinco locos selecionados para este estudo apresentaram bom nível de polimorfismo, nenhum apresentou menos que 11 alelos considerando todas as amostras de F. varia (n=69), sendo que o maior número de alelos foi de 23 (loco Friv14). As taxas médias de heterozigose observada e esperada ( $H o$ e $H e$ ) para as amostras de $F$. varia (campus USP e amostras externas) foram de 0,559 e 0,746 respectivamente (Tabela 18). Francini et al. (2009) isolaram e caracterizaram 9 locos microssatélites em 44 indivíduos de Melipona seminigra. Neste estudo o número de alelos variou de 2 a 8 com $H o$ e $H e$ média de 0,34 e 0,54 respectivamente. Carvalho-Zilse et al. (2009) estudaram 40 indivíduos de Melipona scutellaris provenientes dos estados de Pernambuco, Alagoas, Sergipe e Bahia com cinco locos microssatélites heteroespecíficos e encontraram número de alelos variando de 2 a 10 . Neste estudo as taxas médias de heterozigose observada e esperada foram de 0,35 e 0,55 respectivamente. Francisco (2002) estudou populações de Plebeia remota com sete locos microssatélites e encontrou número de alelos de 1 a 6 . Brito (2005) estudou com nove locos microssatélites populações de Partamona mulata dos estados de Mato Grosso e Mato Grosso do Sul e de Partamona helleri dos estados de Santa Catarina, São Paulo, Minas Gerais, Espírito Santo e Bahia. Para P. mulata o número de alelos variou de 1 a 6 e para $P$. helleri este número variou de 1 a 4.

A maior parte dos estudos descritos acima utilizou primers heteroespecíficos para a amplificação dos locos de microssatélites. Em nosso estudo, o grande número de alelos encontrado pode ser explicado pelo uso de primers específicos para $F$. varia. Ainda, o maior número amostral $(\mathrm{n}=69)$ por nós analisado, em relação aos demais 
estudos, pode também ter influenciado no número de alelos encontrado. Quando usados nas amostras de $F$. trichocerata $(\mathrm{n}=30)$ os locos tiveram número de alelos variando de 12 a 16 (total de 72 alelos - Tabela 18), mostrando que eles têm grande potencial para amplificação cruzada, ou seja, para o uso em espécies próximas, ou como aqui propomos, em ecótipos. Fato este confirmado com o sucesso de amplificação destes primers em outras seis espécies de Meliponini (Artigo aceito para publicação Apêndice 4).

Ao observar a Tabela 17 podemos ver que o número de alelos encontrado foi semelhante para os diferentes grupos amostrais. Este é outro fato que contraria os pressupostos de perda de variabilidade em pequenas populações. Considerando que as amostras do campus da USP parecem estar isoladas, semelhantemente a uma população em um fragmento de mata, seria esperado um menor número de alelos para estas amostras em relação ao encontrado para as amostras externas ao campus.

O número semelhante de alelos encontrado entre as amostras coletadas dentro e fora do campus contraria também os dados de sequências do COI, onde encontramos maior variabilidade das amostras externas em relação ao campus da USP. Para explicar este fato levantamos duas hipóteses. A primeira seria que, como temos indícios de introdução de ninhos no campus da USP, estas amostras trariam consigo alelos de outras localidades que seriam diferentes daqueles que originalmente estavam presentes no campus, aumentando assim a variabilidade daquelas amostras. A segunda hipótese seria de fluxo gênico via macho, onde haveria machos migrando de outras localidades e fecundando as rainhas do campus e introduzindo novos alelos na população.

O fluxo gênico via machos parece também ocorrer com as amostras de $F$. trichocerata, visto que para todos os locos encontramos grande número de alelos, com 
exceção do loco Friv14 (Tabela 17). Esta parece ser a explicação mais plausível, pois o meliponicultor que nos forneceu as amostras de F. trichocerata nos informou que o sítio onde está instalado o seu meliponário é circundado por mata pouco antropizada, tendo assim grandes chances de que machos estejam vindo destas áreas e fecundando fêmeas do meliponário.

Apesar de termos dividido as amostras de $F$. varia coletadas em áreas externas ao campus da USP em grupos baseados em proximidade geográfica, a Tabela 19 mostra que vários locos, quando analisados separadamente, não estavam em Equilíbrio de Hardy-Weinberg (EHW). Isto pode ser explicado pela grande distância entre alguns pontos de coleta, que em alguns casos chega a centenas de quilômetros. Além disso, como visto nas Tabelas 19 e 20, os locos para os quais foi detectada deficiência de heterozigotos são os mesmo que não apresentavam EHW. Por outro lado, quando todos os locos foram considerados em conjunto as únicas amostras que não estavam em EHW eram as do campus da USP e F.trichocerata $\left(\chi^{2}: \infty\right.$ e $P$ : Altamente significativo Tabela 19). Isto corrobora nossa hipótese sobre a existência de fluxo gênico nestes dois grupos amostrais, pois se há fluxo gênico via migrantes (machos) não há EHW.

O teste para detecção de desequilíbrio de ligação entre pares de locos revelou que apenas os locos Friv18 e Friv9 não estavam segregando independentemente nas amostras do campus da USP (Tabela 21), porém quando analisamos todas as amostras em conjunto, nenhum par de locos estava em desequilíbrio de ligação (Tabela 22). Na literatura há relatos de que a deriva genética pode causar desequilíbrio de ligação em populações subdivididas (Nei e Li, 1973; Ohta, 1982). Ainda, segundo Packer e Owen (1990), desequilíbrio de ligação é facilmente detectado em espécies da ordem Hymenoptera devido ao sistema sexual haplodiplóide. Neste caso, como os machos são 
haplóides, eles transferem para sua prole $100 \%$ de seu patrimônio genético, simulando assim uma "ligação" entre todos os seus locos.

Os valores de $F$ st (Tabela 23) revelaram estruturação em diferentes níveis para as amostras do campus da USP em relação aos outros grupos amostrais. Interessantemente o menor valor de $F$ st foi encontrado entre as amostras MT e campus USP $(F$ st $=0,0204)$, contrariando a expectativa de que as amostras do campus da USP seriam mais próximas das amostras SP, dado que elas estão geograficamente mais próximas. Entretanto, esta maior proximidade entre campus USP e MT confirma os indícios de transporte de ninhos entre o estado de Mato Grosso e o campus, fato este que estaria aproximando estes dois grupos amostrais. Além disso, o número amostral de MT é pequeno, o que pode interferir nesses resultados.

Apesar de os valores de $F$ st terem revelado certa estruturação, as amostras de F. varia do campus da USP parecem não apresentar altas taxas de endocruzamento, visto que o valore de $F$ is encontrado para estas amostras é baixo, chegando a ser menor inclusive que as amostras de GO-MT-MG, que são provenientes de áreas naturais (Tabela 26). Fato este que pode ser devido ao fluxo gênico via macho, que introduz novos alelos naquela área, minimizando os efeitos da endogamia.

Este trabalho foi pioneiro em estudar a estrutura populacional de $F$. varia utilizando marcadores moleculares de herança materna e paterna em conjunto com marcadores morfológicos, tendo como produção técnica resultante um conjunto de primers para amplificar locos microssatélites específicos desta espécie, e que também pode ser utilizado para amplificar locos de outras espécies (artigo Apêndice 4). Nossos resultados também forneceram informações importantes a respeito da validação de duas 
espécies do gênero Frieseomelitta que poderão ser levadas em consideração em ações de conservação das espécies deste gênero.

Para melhor responder a questão da colonização natural de novas áreas por $F$. varia são necessários estudos com diferentes metodologias de coleta, como por exemplo, a coleta em um fragmento de mata natural e em seus arredores, onde se saiba que não houve introdução de ninhos (por ação humana). Assim seria possível identificar os alelos e haplótipos que realmente pertencem àquela população, estimando com maior precisão as linhagens mitocondriais que deram origem à população e qual a efetiva contribuição dos machos para a redução da endogamia naquele fragmento. Ainda, a coleta e genotipagem dos machos forneceria um panorama da real produção de machos diplóides naquela área e assim confirmar se de fato a perda de variabilidade genética está prejudicando aquela população. 


\section{Conclusões}

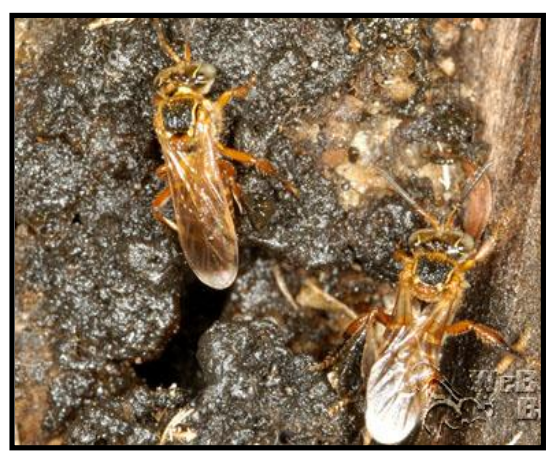


1. O cenário genético observado nas amostras de Frieseomelitta varia do campus USP-RP não corroborou nossa hipótese inicial de que encontraríamos uma situação de baixa variabilidade genética e endogamia. Ao contrário, o nível de diversidade genética tanto por marcadores de origem exclusivamente materna (DNAmt) quanto de origem biparental (microssatélites), mostraram alta variabilidade genética (9 haplótipos mitocondriais e locos de microssatélites com 11 a 23 alelos). Esse cenário pode ser explicado por mais de uma hipótese:

a: A atual população residente do campus deve ter se originado a partir de pelo menos nove ninhos fundadores portando cada um diferentes alelos nucleares;

b: Pelo menos nove enxames diferentes teriam fundado a população que atualmente reside no campus e a alta variabilidade nuclear seria explicada por fluxo gênico via macho. Considerando que ninhos de $F$. varia não são encontrados em áreas circunvizinhas ao campus e que as rainhas de Meliponíneos são filopátricas, ou seja, têm menor capacidade de dispersão devido à dependência do ninho mãe, a probabilidade de que novos ninhos estejam sendo atraídos para aquela área parece ser baixa. No entanto, como machos têm maior capacidade de vôo que as fêmeas, eles estariam vindo de regiões mais distantes e fecundando as rainhas do campus, introduzindo assim novos alelos naquela população.

c: O maior número de linhagens mitocondriais encontrado no campus em relação às amostras externas pode ser fruto de introdução de ninhos de outras regiões naquela área, hipótese esta levantada pela grande similaridade entre haplótipos encontrados apenas em regiões distantes entre si, como o campus da USP e o estado do Mato Grosso, e pelos indícios históricos a respeito de transporte de ninhos para o campus. Desse modo novos alelos nucleares também seriam introduzidos. 
2. A morfometria geométrica das asas não foi sensível o bastante para separar amostras de F. varia coletadas em diferentes situações (áreas naturais e antrópicas), porém foi muito eficiente na validação das espécies incluídas neste trabalho, portanto, sendo indicada para estudos que visem comparações interespecíficas.

3. Assim como a morfologia das asas, o gene COI isoladamente não foi sensível o bastante para detectar as nove linhagens mitocondriais existentes no campus atualmente, sendo, portanto, necessária a análise em paralelo de outros genes com diferentes taxas de acúmulo de substituições em estudos de variação intraespecífica. Por si só este gene (COI) seria indicado para a avaliação interespecífica. Em nosso caso, o gene $C O$ I foi também muito útil na validação das espécies estudadas. Este marcador foi sensível o bastante para detectar níveis significativos de diferenciação genética entre duas espécies ( $F$. varia e $F$. doederleini) e agrupar outras duas ( $F$. varia e $F$. trichocerata), levando-nos a postular que $F$. trichocerata não deve ser considerada como uma espécie, mas sim como uma variação geográfica (ecótipo) de $F$. varia.

4. Como o meliponário de Espigão do Oeste (amostras de $F$. trichocerata) foi fundado por dois ninhos ancestrais, o número superior ao esperado de haplótipos encontrado (no máximo 2), seria devido à invasão de caixas racionais por ninhos de outras localidades introduzindo novas linhagens mitocondriais. Ainda, o grande número de alelos encontrado para aquelas amostras é também explicado por fluxo gênico via machos, visto que a área do meliponário é circundada por mata pouco antropizada. 


\section{Resumo}

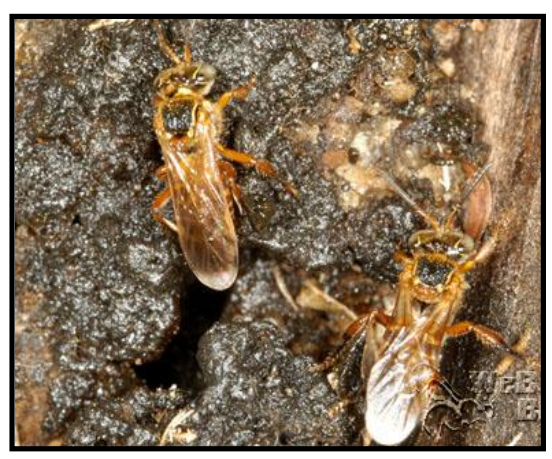


GONÇALVES, P.H.P. (2010). Análise da variabilidade genética de uma pequena população de Frieseomelitta varia (Hymenoptera, Apidae, Meliponini) por meio de análise do DNA mitocondrial, microssatélites e morfometria geométrica das asas. Dissertação de Mestrado-Instituto de Biociências, Universidade de São Paulo.

As abelhas da tribo Meliponini apresentam distribuição pantropical. São encontradas mais de 400 espécies pertencentes a 50 gêneros, sendo que mais de 300 estão presentes nas Américas. Os meliponíneos são responsáveis por grande parte da polinização das plantas nativas. A destruição das florestas tem ameaçado seriamente as abelhas sem ferrão, isolando-as em fragmentos e expondo-as ao endocruzamento e aos efeitos de perda de variabilidade genética. No presente estudo, foram empregadas análises moleculares (PCR-RFLP, análise de locos de microssatélites e o sequenciamento de um trecho do gene COI) e morfométrica (Análise da Morfometria Geométrica das asas) no intuito de se verificar a variabilidade em uma pequena população de Frieseomelitta varia residente no campus da USP de Ribeirão Preto ( $n=33)$. Para comparação, foram coletados e analisados indivíduos de áreas externas ao campus, ao longo da distribuição natural da espécie $(n=36)$ e também de duas outras espécies, $F$. trichocerata $(\mathrm{n}=30)$ e $F$. doederleini $(\mathrm{n}=3)$. Os resultados mostraram maior variabilidade mitocondrial e nuclear para o campus da USP em relação às amostras externas. Pelo menos nove matrilinhagens originaram a população do campus. O grande número de alelos encontrados nas amostras do campus pode ser explicado pela introdução de ninhos, por alta variabilidade já existente nos ninhos fundadores e/ou fluxo gênico via machos. Os resultados moleculares e morfológicos mostram grande similaridade entre $F$. varia e $F$. trichocerata, e em contraste, grande distância entre $F$. varia e $F$. doederleini, indicando que $F$. trichocerata deve ser considerada como uma variação geográfica (ecótipo) de $F$. varia. 


\section{Abstract}

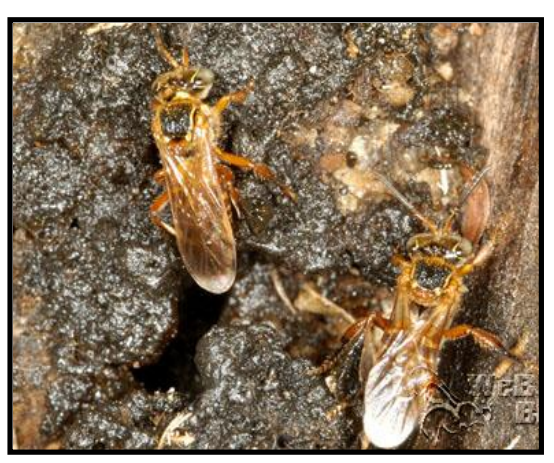


GONÇALVES, P.H.P. (2010). Analysis of the genetic variability of a small population of Frieseomelitta varia (Hymenoptera, Apidae, Meliponini) through mitochondrial DNA analysis, microsatellites and geometric morphometry of wings. Master degree dissertation-Instituto de Biociências, Universidade de São Paulo.

The stingless bees present a pantropical distribution. There are more than 400 species belonging to 50 genera. More than 300 are present in the Americas. These bees have a remarkable role in the pollination of native plants. Forest destruction has threatened stingless bees populations by isolating them in forest fragments and exposing them to the effects of inbreeding and loss of genetic variability. In the present study we applied molecular (PCR-RFLP, microsatellite loci analysis and COI sequencing) and morphometric (Geometric Morphometry of Wings) analysis to verify the genetic variability of a small population of Frieseomelitta varia $(n=33)$ resident in the campus of USP - Ribeirão Preto. For comparison, individuals collected across the species natural geographic range and also samples of two other species, $F$. trichocerata $(\mathrm{n}=30)$ and $F$. doederleini $(\mathrm{n}=3)$, were analyzed. The results showed greater mitochondrial and nuclear variability for the samples from the campus in relation to the species overall. Nine matrilines, at least, gave rise to the current campus colonies. The large microsatellite allele number can be explained by recurrent nests introduction, or by high variability already present in the founder nests and/or current gene flow mediated by males. The molecular and morphometric data show high similarity between $F$. varia and $F$. trichocerata, and in contrast, high distance between $F$. varia and $F$. doederleini, indicating that $F$. trichocerata should be considered as a geographic variation (ecotype) of $F$. varia. 


\section{Referências Bibliográficas}

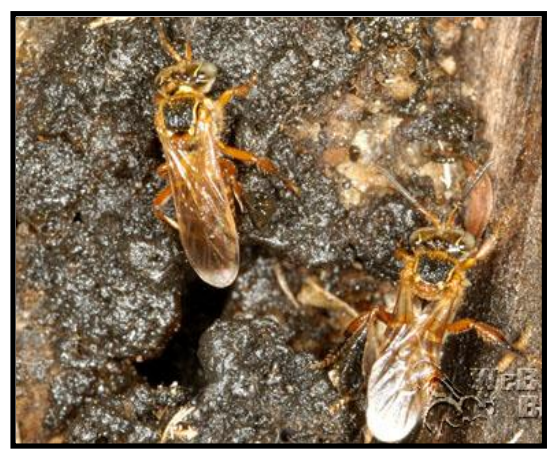


ALVES, D. A. (2010). Estratégias reprodutivas em Melipona com ênfase em pequenas populações de Melipona scutellaris (Apidae, Meliponini). Tese de Doutorado. Departamento de Ecologia - Instituto de Biociências, Universidade de São Paulo. $102 p$.

ARIAS, M. C., SHEPPARD, W. S. (1996). Molecular phylogenetics of honey bee subspecies (Apis mellifera 1.) Inferred from mitochondrial DNA sequences. Mol. Phylogenet. Evol. 5: 557-566.

ASSIS, A. F. (2010). Estudo populacional e molecular de Nannotrigona testaceicornis Cockerell (Hymenoptera, Apidae, Meliponini) através do DNA mitocondrial. Dissertação de mestrado. Departamento de Genética - Faculdade de Medicina de Ribeirão Preto, Universidade de São Paulo.

BAPTISTElla A. R. T. O., SILVA C. C. M., ASSIS A. F., AKATSU I. P., SOARES A. E. E. (2007). Distribuição espacial dos ninhos de Frieseomelitta varia no campus da USP, Ribeirão Preto - SP. Caderno de Resumos do XXV Encontro Anual de Etologia. São José do Rio Preto: Editora da UNESP. p. 234-234.

BEEBEE, T. J. C., ROWE, G. (2004). Conservation genetics. In: An introdution to molecular ecology. Oxford University Press. New York. Pg 199-222.

BEYE, M., HASSELMANN, M., FONDRK. M. K., PAGE, R. E. Jr, OMHOLT, S. W. (2003). The gene $c s d$ is the primary signal for sexual development in the honeybee and encodes an sr-type protein. Cell 114: 419-429.

BIJLSMA, R., BUNDGAARD, J., BOEREMA, A. C. (2000). Does inbreeding affect the extinction risk of small populations?: Predictions from Drosophila. J . Evol. Biol. 13: 502-514. 
BILlotTe N., LAGODA, P.J.R., RISTERUCCI, A.M., BAURENS, F.C. (1999). Microsatellite-enriched libraries: Applied methodology for the development of SSR markers in tropical crops. Fruits. 54: 277-288.

BOOKSTEIN, F. L. (1991) Morphometric tools for landmark data. Cambridge: Cambridge University Press.

BRITO, R. M. (2005). Análise molecular e populacional de Partamona mulata (Moure in Camargo, 1980) e Partamona helleri (Friese, 1900) (Hymenoptera, Apidae, Meliponini). São Paulo, USP, 189p. Tese de Doutorado (Biologia Genética). Universidade de São Paulo.

BRITO, R. M., FRANCISCO, F. O., DOMINGUES-YAMADA, A. M. T., GONÇAlves, P. H. P., PIOKER, F. C., SOARES, A. E. E., ARIAS, M. C. (2009). Characterization of microsatellite loci of Tetragonisca angustula (Hymenoptera, Apidae, Meliponini). Conservation Genetics Resources. DOI: 10.1007/s12686-009-9045-4.

BRITO, R. M., ARIAS, M. C. (2010). Genetic structure of Partamona helleri (Apidae,Meliponini) from Neotropical Atlantic rainforest. Insects Sociaux. DOI: 10.1007/s00040-010-0098-x.

BROWN, W. M. (1985). The mitochondrial genome of animals. In "molecular evolutionary genetics” (R.J. MacIntyre, Ed.), pp. 95-130, Plenus Press, New York.

CAMARGO, J. M. F., PEDRO, S. R M. (1992). Systematics, phylogeny, and biogeography of the Meliponinae (Hymenoptera, Apidae): A mini-review. Apidologie 23: 509-522. 
CAMARGO, J. M. F., PEDRO S. E. M. (2008) MELIPONINI LEPELETIER, 1836. In Moure, J.S., Urban D., Melo, G. A. R (Orgs). Catalogue of bees (hymenoptera, apoidea) in the neotropical region - Versão online. Disponível em http://www.moure.cria.org.br/catalogue. Acessado 25/11/2009.

CARVALHO-ZILSE, G. A., COSTA-PINTO M. F. F., NUNES-SILVA, C. G., KERR, W. E. (2009). Does beekeeping reduce genetic variability in Melipona scutellaris (Apidae, Meliponini)? Genetics and Molecular Research 8: 758-765.

COLLET, T., FERREIRA, K. M., ARIAS, M. C., SOARES, A. E. E., DEL LAMA, M. A. (2006). Genetic structure of africanized honeybee populations (Apis mellifera l.) from Brazil and Uruguay viewed through mitochondrial DNA COI-COII patterns. Heredity 97: 329-335.

COLlET, T., ARIAS, M. C., DEL LAMA, M. A. (2007). 16s mtDNA variation in Apis mellifera detected by PCR-RFLP. Apidologie 38: 47-54.

COUVILLON M. J.; RATNIEKS F. L.W. (2008). Odour transfer in stingless bee marmelada (Frieseomelitta varia) demonstrates that entrance guards use an "undesirable-absent" recognition system. Behav. Ecol. Sociobiol. 62: 1099-1105.

COWAN, D. P., STAHLHUT, J. K. (2004). Functionally reproductive diploid and haploid males in an inbreeding hymenopteran with complementary sex determination. PNAS 101: 10374-10379.

CROZIER R. H., CROZIER Y. C. (1993). The mitochondrial genome of the honeybee Apis mellifera: Complete sequence and the genome organization. Genetics 133: 97117. 
CURTOPASSI- LAURINO, M., RIBEIRO, M. F., NOGUEIRA-NETO, P., ROSSO, J. M. L. (2002). Nidificação de abelhas sem ferrão em um cerrado de Goiás. Anais do V Encontro Sobre Abelhas, Ribeirão Preto, SP. P. 303.

DE BOER, J. G., ODE, P. J., VET, L. E. M.,WHITIELD, J. B., HEIMPEL, G. (2007). Diploid males sire triploid daughters and sons in the parasitoid wasp Cotesia vestalis. Heredity 99: 288-294.

DE BOER, J. G., ODE, P. J., RENDAHL, A. K., VET, L. E. M., WHITFIELD, J. B., HEIMPEL, G. (2008). Experimental support for multiple locus complementary sex determination in the parasitoid Cotesia vestalis. Genetics 180: 1525-1535.

DEL LAMA, M. A., LOBO, J. A., SOARES, A. E. E., DEL LAMA, S. N. (1990). Genetic differentiation estimated by isozymic analysis of africanized Honey Bee populations from Brazil and from central america. Apidologie 21: 271-280.

DOWNling, T. E., MORITZ, C., PALMER, J. D., RIESEBERG, L. H. (1996). Nucleic acids III: Analysis of fragments and restriction sites. In: Molecular Systematics. 2nd edn. Sinauer Associates Inc., Massachusetts.

EDGAR, R. C. (2004). Muscle: Multiple sequence alignment with high accuracy and high throughput. Nucleic Acids Research 32: 1792-97.

ELLSTRAND, N. C., ELAN D. R. (1993). Population genetic consequences of small population size: Implications for plant conservation. Annual Review of Ecology and Systematics, 24: 217-242.

EL-NIWEIRI, M. A. A., MORITZ R. F. A. (2008). Mitochondrial discrimination of honeybees (Apis mellifera) of sudan. Apidologie 39: 566-573. 
ESTOUP, A., SOLIGNAC, M., HARRY, J. M. CORNUET. (1993). Characterization of (GT)n and (CT)n microssatellites in two insect species: Apis mellifera AND Bombus terrestris. Nucleic Acids. 21: 1427-1431.

ESTOUP, A., GARNERY, L., SOLIGNAC, M., CORNUET, J.M. (1995). Microsatellite variation in honey bee (Apis mellifera 1.) Populations: Hierarchical genetic structure and test of the infinite allele and stepwise mutation models. Genetics 140: 679-695.

ESTOUP, A., SOLIGNAC, M., CORNUET, J. M., GOUDET, J. SCHOOL, A. (1996). Genetic differentiation of island and continental populations of Bombus terrestris (Hymenoptera: Apidae) in Europe. Mol. Ecol. 5: 19-31.

EXCOFFIER, L., SMOUSE, P. E., QUATTRO, J. M. (1992). Analysis of molecular variance inferred from metric distances among DNA haplotypes: application to human mitochondrial DNA restriction data. Genetics 131: 479-491.

EXCOFFIER, L. G. L., SCHNEIDER S. (2005). Arlequin ver. 3.0: An integrated software package for population genetics data analysis. Evolutionary Bioinformatics Online 1:47-50.

FAUSTINO, C. D., ZUCCHI, R., NOGUEIRA-FERREIRA, F. H. (2002). Polietismo etário entre mini-colônias de Frieseomelitta varia (Hymenoptera: Apidae: Meliponini). Anais do V Encontro Sobre Abelhas, Ribeirão Preto, SP. P. 314.

FIGUEIREDO, G. P., FAUSTINO, C. D., COSTA, L. M., ZUCCHI, R. (2002). Longevidade e polietismo etário de operárias em colônias normais de Frieseomelitta varia e Frieseomelitta silvestrii (Hymenoptera, Apidae, Meliponini). Anais do V Encontro Sobre Abelhas, Ribeirão Preto, SP. P. 316. 
FRANCINI, I. B., SFORÇA, D. A., SOUSA, A. C. B., CAMPOS, T., CIDADE, F. W., ZUCCHI, M. I., SOUZA, A. P., NUNES-SILVA C. G., CARVALHO-ZILSE, G. A. (2009). Microsatellite loci for an endemic stingless bee Melipona seminigra merrillae (Apidae, Meliponini) from Amazon. Conservation genetics resources DOI 10.1007/s12686-009-9113-9.

FRANCISCO, F.O., SILVESTRE, D., ARIAS, M.C. (2001). Mitochondrial DNA characterization of five species of Plebeia (Apidae: Meliponini): RFLP and restriction maps. Apidologie, 32: 323-332.

FRANCISCO, F.O. (2002). Diversidade genética de populações de abelha sem ferrão plebeia remota: análise do DNA mitocondrial e microssatélites. São Paulo, USP, 140p. Dissertação de mestrado. (Biologia Genética). Universidade de São Paulo.

FRANCISCO, F. O., BRITO, R. M., ARIAS, M. C. (2006). Alelle number and heterozigosity for microsatellite loci in different stingless bee species (Hymenoptera: Apidae, Meliponini). Neotropical Entomology 35: 638-643.

FRANCISCO, F. O., NINES-SILVA, P., FRANCOY, T. M., WITTMANN, D., FONSECA, V. L. I., ARIAS, M. C., MORGAN, E. D. (2008). Morphometrical, biochemical and molecular tools for assessing biodiversity. An example in Plebeia remota (Holmberg, 1903) (Apidae, Meliponini). Insectes Sociaux, 55: 231-237.

FRANCISCO, F. O. (2009). FOFpop v.2.0, a pool of Microsoft Excel sheets to analyse genotypic data. Disponível em: http://www.ib.usp.br/ lgea/fofpop.

FRANCISCO, F. O., ARIAS, M. C. (2010). Inferences of evolutionary and ecological events that influenced the population structure of Plebeia remota, a stingless bee from Brazil. Apidologie 41: 216-224. 
FRANCK, P., GARNERY, L., SOLIGNAC, M., CORNUET, J. M. (1998). The origin of west european subspecies of Honeybees (Apis mellifera) new isights from microsatellite and mitochondrial data. Evolution 52, 1119-1134.

FRANCOY, T. M., GONÇALVES, L. S., WITTMANN, D. (2006). Changes in the patterns of wing venation of Africanized honey bees over time. Anais do VII Encontro sobre Abelhas. p. 173-177.

FRANCOY, T. M. (2007). Variabilidade genético-morfológica em populações neotropicais de Apis mellifera. Ribeirão Preto, USP. Tese de Doutorado, FMRP. Universidade de São Paulo, Ribeirão Preto.

FRANCOY, T. M., WITTMANN, D., DRAUSCHKE, M., MULLER, S., STEINHAGE, V., BEZERRA-LAURE, M. A. F., DE JONG, D., GONÇALVES L. S. (2008). Identification of africanized Honeybees through wing morphometrics: two fast and eficient procedures. Apidologie 39: 488-494.

FRANKHAM, R., BALLOU, J. D., BRISCOE D. A. (2004). Genetic consequences of small population size in: A primer of conservation genetics. Editora da Universidade de Cambridge. Cambridge-UK. Pg 52 a75.

FREITAS, G. S. (2001). Levantamento de ninhos de meliponíneos (Hymenoptera, Apidae) em área urbana: Campus da USP, Ribeirão Preto/SP. Dissertação de mestrado. FFCLRP. Ribeirão Preto, SP. 84p.

GARNERY, L., VAUTRIN, J. M., CORNUET, J. M., SOLIGNAC, M. (1991). Phylogenetics relationships in the genus Apis inferred from mitocondrial DNA analysis. Mol. Ecol. 1: 2317-2331. 
GARNERY, L., CORNUET, J. M., SOLIGNAC, M. (1992). Evolutionary history of the honey bee Apis mellifera inferred from mitochondrial DNA analysis. Mol. Ecol. 1: 145-154.

GOUDET, J., RAYMOND, M., DE MEEÜS, T., ROUSSET, F. (1996) Testing differentiation in diploid populations. Genetics 144: 1933-1940.

GREEN, C. L., FRANCK, P., OLDROYD, B. P. (2001). Characterization of microsatellite loci for Trigona carbonaria, a stingless bee endemic to Australia. Mol. Ecol. Notes 1:89-92.

HAJIBABAEI, M., JANZEN, D. H., BURNS, J. M., HALLWACHS, W., HEBERT, P. D. N. (2005). DNA barcodes distinguish species of tropical Lepidoptera. PNAS 103: $968-971$.

HALL, H. G., SMITH, D.R. (1991). Distinguishing african and european Honeybee matrilines using amplified mitochondrial DNA. Proc. Natl. Acad. Sci. USA, 88: $4248-4552$.

HALL, T. A. (1999). Bioedit: A user-friendly biological sequence alignment editor and analysis program for windows 95/98/NT. Nucl. Acids. Symp. 41: 95-98.

HASSELMANN, M., GEMPE, T., SCHIØTT, M., NUNES-SILVA, C. G., OTTE, M., BEYE, M., (2008). Evidence for the evolutionary nascence of a novel sex determination pathway in honeybees. Nature 454: 19-522.

HARRISON, R. G. (1989). Animal mitochondrial DNA as a genetic marker in population and evolutionary biology. Tree 4: 6-11. 
HEARD, T. A. (1999). The role of stingless bees in crop pollination. Annu. Rev. Entomol.44: 183-206.

HEBERT, P. D. N., SUJEEVAN, R., WAARD, J. R. (2003). Barcoding animal life: cytochrome $c$ oxidase subunit 1 divergences among closely related species. Proc. R. Soc. Lond. 270: 96-99.

HEDRICK, P. W., GADAU, J., PAGE Jr., R. E. (2006). Genetic sex determination and extinction. TREE 21: 55-57.

HEIN, S., POETHKEB, H. J., DORNA, S. (2009). What stops the 'diploid male vortex'? - a simulation study for species with single locus complementary sex determination. Ecological Modelling 220: 1663-1669.

HEPBURN, H. R., SMITH, D. R., RADLOFF, S. E., OTIS, G. W. (2001). Infraspecific categories of Apis cerana: Morphometric, allozymal and mtDNA diversity. Apidologie 32, 3-23.

HGSC-HONEYBEE GENOME SEQUENCING CONSORTIUM. (2006). Insights into social insects from the genome of the honeybee Apis mellifera. Nature 443: 931949.

HILLIS, D. M., MORITZ, C., MABLE, B. K. (1996). Molecular systematics. 2nd edn. Sinauer Associates Inc., Massachusetts.

IHERING, H. (1912). Zur Biologie der brasilianischen Meliponiden. Z. Wiss. Insektenbiol. 8: 1-5. 
KANDEMIR, I., KENCE, M., KENSE, A. (2005). Morphometric and electrophoretic variation in different Honeybee (Apis mellifera l.) Populations. Turk. J. Vet. Anim. Sci. 29: 885-890.

KANDEMIR, I., MEIXNER, M. D., OZKAN A., SHEPPARD, W. S. (2006). Genetic characterization of honey bee (Apis mellifera cypria) populations in northern cyprus. Apidologie 37: 547-555.

KERR, W. E; VENCOVSK, R. (1982). Melhoramento genético em abelhas I. Efeito do número de colônias sobre o melhoramento. Brazilian. Journal of Genetics. v. 5, p. 279-285.

KERR, W. E., CARVALHO, G. A. E NASCIMENTO, V. A. (1996). A abelha uruçu: biologia, manejo e conservação. Fundação Acangáu, Belo Horizonte-MG.

KERR, W. E. (1997) Meliponicultura. A importância da meliponicultura para o país. Biotecnologia Ciência e Desenvolvimento 1: 42-44.

KERR, W. E., CARVAlho, G. A., COletto DA SIlVA, A., ASSiS, M. G. P. (2001). Aspectos pouco mencionados da biodiversidade amazônica, p. 20-41. In: MINISTÉRIO DA CIÊNCIA E TECNOLOGIA (Ed.). Biodiversidade, Pesquisa e Desenvolvimento na Amazônia. Parcerias Estratégicas. Brasília, vol. 12.

KRAUS, F. B., WEINHOLD, S., MORITZ, R. F. A. (2007). Genetic structure of drone congregations of the stingless bee Scaptotrigona mexicana. Insectes Sociaux 55: $22-27$.

LIBRADO, P., ROSAS, J. (2009). DnaSP v5: A software for comprehencive analysis of DNA polymorphism data. Bioinformatics 25: 1451-1452. 
LEPELETIER, A. L. M. (1836). Histoire Naturelle des Insectes- Hyménoptères. Paris: Roret Vol. 1 1-547 pp. 433.

LOBO, J. A., DEL LAMA, M. A. AND MESTRINER, M. A. (1989). Population differentiation and racial admixture in the africanized Honeybee (Apis mellifera l.). Evolution 43: 794-802.

LOPES, E. M., SILVA, F. O., FERNANDES-SALOMÃO, T. M., CAMPOS, L. A. O., TAVARES M. G. (2009a). Microsatellite loci for the stingless bee Melipona rufiventris (Hymenoptera: Apidae). Mol. Ecology Resources 9: 923-925.

LOPES, D. M., SILVA F. O., FERNANDES-SALOMÃO, T. M., CAMPOS, L. A. O., TAVARES M. G. (2009b). A scientific note on the characterization of microsatellite loci for Melipona mondury (Hymenoptera: Apidae). Apidologie DOI: 10.1051/apido/2009067.

LYNCH, M., GABRIEL, W. (1990). Mutation load and the survival of small populations. Evolution 44: 1725-1737.

MALAGODI-BRAGA, K. S., KLEINERT, A. M. P. (2002). A produção de morangos sob efeito da polinização por jataí (Tetragonisca angustula). Anais do V Encontro Sobre Abelhas, Ribeirão Preto, SP.

MCELROY, D.; MORAN, P.; BERMINGHAM, E., KORNFIELD, I. (1992). REAP: An integrated environment for the manipulation and phylogenetic analysis of restriction data. The Journal of Heredity 83: 157-158.

MENDES, M. F. M., FRANCOY, T. M., NUNES-SILVA, P., MENEZES, C., IMPERATRIZ-FONSECA, V. L. (2007) Intra-populational variability of 
Nannotrigona testaceicornis Lepeletier 1836 (Hymenoptera, Meliponini) using relative warp analysis. Biosci. J., 23: 147-152.

MEIXNER, M.D., ARIAS, M.C., SHEPPARD, W.S. (2000) Mitochondrial DNA polymorphisms in Honey bee subspecies from Kenya. Apidologie 31, 181-190.

MESQUiTA, F. L. A., ALVES, J. E., FREITAS, B. M. (2002) Padrão diário de trabalho de operárias dos ninhos de moça branca (Frieseomelitta varia) ao longo do dia. Anais do V Encontro Sobre Abelhas, Ribeirão Preto, SP. P. 311.

MICHENER, C. D. (2007). The bees of the world. Segunda edição. The Johns Hopkins University Press. Baltimore. 953p.

MORITZ, C., DOWLING, T. E., BROWN, W. M. (1987). Evolution of animal mitochondrial DNA. Relevance for population biology and systematics. Ann. Rev. Ecol. Syst. 18: 269-292.

MOURE, J. S. (1988). Uma nova espécie de Frieseomelitta do oeste da Amazônia. Acta Biol. Par. 17: 141-145.

NEI, M., LI, W. H. (1973). Linkage disequilibrium in subdivided populations. Genetics 75: 213-219.

NEI, M., TAJIMA F. (1981). DNA polymorphism detectable by restriction endonucleases. Genetics 97: 145-163.

NEI, M. (1987). Molecular Evolutionary Genetics. Columbia University Press, New York. 
NEWMAN, D., PILSON D. (1997). Increased probability of extinction due to decreased genetic effective population size: experimental populations of Clarkia pulchella. Evoltuion 51: 354-362.

NOGUEIRA-NETO, P. (1997). Vida e criação de abelhas indígenas sem ferrão. Editora Nogueirapis. São Paulo, SP. 445 p.

NOGUEIRA-NETO, P. (2002). Imbreeding and builting up a small population of stingless bees. Revista Brasileira de Zoologia. 19: 1181-1214.

NUNES T. M., TURATTI, I. C. C., LOPES N. P., ZUCCHI R. (2008). Reconhecimento em abelhas sem ferrão. Anais do VIII Encontro sobre Abelhas. Ribeirão Preto, SP. Editora Funpec.p. 81-86.

OHTA, T. (1982). Linkage disequilibrium due to random genetic drift in finite subdivided populations. PNAS 79: 1940-1944.

OLIVEIRA, F. F. (2003). Revisão do gênero Frieseomelitta von Ihering, 1912 (Hymenoptera, Apidae, Meliponinae), com notas bionômicas de algumas espécies. Tese de Doutorado, Universidade Federal do Paraná, Curitiba, 327p.

OLIVEIRA, E. J. F., FREITAS G. S., FONSECA, A. S., SOUSA, A. C. B., CAMPOS, T, ASSIS, A. F., SOUZA, A. P., CONTEL, E. P. B., SOARES, A. E. E. (2009). Isolation and characterization of microsatellite markers from the stingless bee Nannotrigona testaceicornis. Conservation Genetics Resources. doi: 0.1007/s12686-009-9023-x.

PACKER, L., OWEN, R. E. (1990). Allozyme variation, linkage disequilibrium and diploid male production in a primitively social bee Augochlorella striata (Hymenoptera; Halictidae). Heredity 65: 241-248. 
PAXTON, R. J., WEIßSCHUH, N., QUEZADA-EUÁN, J. J. G. (1999a). Characterization of dinucleotide microsatellite loci for stingless bees. Mol. Ecol. 8: 690-692.

PAXTON, R. J., WEIßSCHUH, N., ENGELS, W., HARTFELDER, K., QUEZADAEUÁN, J. J. G. (1999b). Not only single mating in stingless bees. Naturwissenschaften 86: 143-146.

PEAKALL, R., SMOUSE, P. E. (2006). GENALEX 6: genetic analysis in Excel. Population genetic software for teaching and research. Molecular Ecology Notes 6: 288-295.

PETERS, J. M., QUELLER, D. C.; IMPERATRIZ-FONSECA, V. L., STRASSMANN, J. E. (1998). Microsatellite loci for stingless bees. Mol. Ecol. 7: 787-787.

POLZIN, T., DANESCHMAND,S. V. (2003). On steiner trees and minimum spanning trees in hypergraphs. Operations Research Letters 31: 12-20.

QUEZADA-EUÁN, J. J. G., PAXTON, R. J., PALMER, K. A., ITZÁ, W. J. M., TAY, W. T., OLDROYD, B. P. (2007). Morfological and molecular characters reveal differentiation in a neotropical social bee, Melipona beecheii (Apidae: Meliponini). Apidologie 38: 247-258.

RANDI, E., LUCCHINI, V., CHRISTENSEN, M. F., MUCCI N., FUNK S. M., DOLF G., LOESCHCKE, V. (2000). Mitochondrial DNA variability in italian and east european wolves: Detecting the consequences of small population size and hybridization. Conservation biology 14: 464-473.

RAYMOND, M. E., ROUSSET, F. (1995a) An exact test for population differentiation. Evolution 49: 1280-1283. 
RAYMOND, M., ROUSSET, F. (1995b). Genepop (version 1.2): Population genetics software for exact tests and ecumenicism. J. Heredity, 86: 248-249.

RODRIGUES, L. A., SANTOS, V. F. (2003) Morfometria geométrica - Aplicações em paleobiologia de dinossaurios. Ciências da Terra. (UNL), Lisboa, $\mathrm{n}^{\circ}$ esp. V, CDROM, pp. A141-A145.

ROHLF, F. J., MARCUS, L. F. (1993) A revolution in morphometrics. Trends in Ecology \& Evolution 8: 129-132.

ROHLF, F. J. tpsUtil, Version 1.33. (2004). Department of Ecology and Evolution, State University of New York, Stony Brook.

ROHLF, F .J. tpsDig, Version 2.04. (2005a). Department of Ecology and Evolution, State University of New York, Stony Brook.

ROHLF, F. J. tpsRelw, Version 2.04. (2005b). Department of Ecology and Evolution, State University of New York, Stony Brook.

ROSS, K. G. (2001). Molecular ecology of social behaviour: analyses of breeding systems and genetic structure. Molecular Ecology 10:265-284.

ROZEN, S., SKALETSKY, H. J. (1998). Primer3. Code available at http://wwwgenome.wi.mit.edu/genome_software/other/primer3.html.

RUTTNER, F., TASSENCOURT, L., LOUVEAUX, J. (1978). Biometrical satistical analysis of the geographic variability of Apis mellifera L. Material and Methods. Apidologie 9: 363381.

SAMBROOK, J., FRITSCH, E. F., MANIATS, T. (1989). Molecular cloning: a laboratory manual. $2^{\text {nd }}$ edition. Cold Sprig Harbor Laboratory Press, USA. 
SHEARER, T. L., VAN OPPEN, M. J. H., ROMANO, S. L. \& WORHEIDE, G. (2002). Slow mitochondrial DNA sequence evolution in the Anthozoa (Cnidaria). Mol. Ecol. 11, 2475-2487.

SHEFFIELD, C. S., HEBERT, P.D.N., KEVAN, P. G., PACKER, L. (2009). DNA barcoding a regional bee (Hymenoptera: Apoidea) fauna and its potential for ecological studies. Mol Ecol Resources 9: 196-207.

SHEPPARD, W.S., MCPHERON, B. (1991). Ribossomal dna diversity in apidae. In: diversity in the genus Apis (ed. Smith D.R.), Westview Press, Oxford.

SHEPPARD, W. S.; ARIAS, M. C., SHIMANUKI, H. (1994). Determination of mitochondrial DNA haplotypes from sting remnants of the honeybee Apis mellifera (Hymenoptera, Apidae). Bull. Entomol. Res. 84: 551-554.

SILVEIRA, F. A., MELO, G. A. R., ALMEIDA, E. A. B. (2002). Abelhas brasileiras sistemática e identificação. Editora Composição e Arte, Minas Gerais, Brasil. $1^{\text {a }}$ edição. Pg 86.

SILVESTRE, D., DOWTON, M., ARIAS M. C. (2008). The mitochondrial genome of the stingless bee Melipona bicolor (Hymenoptera, Apidae, Meliponini): Sequence, gene organization and a unique tRNA translocation event conserved across the tribe Meliponini. Genetics and Molecular Biology. 31: 451-460.

SIMON, C.; FRATI, F., BECKNBACH, A., CRESPI, B., LIU, H., FLOOK, P. (1994). Evolution, weighting, and phylogenetic utility of mitochondrial gene sequences and a compilation of conserved polymerase chain reaction primers. Ann. Entomol. Soc. Am. 87: 651-701. 
STATSOFT Inc. (2003). Statistica 6.0. Disponível em http://www.statsoft.com. Acessado em 10/06/09.

STRANGE, J. P., GARNERY, L., SHEPPARD W. S. (2008). Morphological and molecular characterization of the landes honeybee (Apis mellifera l.) Ecotype for genetic conservation. J Insect Conserv. 12: 527-537.

STRASSMANN, J. E., SOlís, C. R., PETERS, J. M., QUELlER, D. C. (1996). Strategies for finding and using highly polymorphic dna microsatellite loci for studies of genetic relatedness and pedigrees. In "Molecular methods in zoology" (J.D. Ferraris e S.R. Palumbi, Eds.), p. 163-178, 528-549, Wiley-Liss, Inc, New York.

SUZUKI, K. M., ARIAS, M. C., GIANGARELli, D. C., FREIRIA, G. A., SOFIA, S. H. (2010). Mitochondrial DNA Diversity of Orchid Bee Euglossa fimbriata (Hymenoptera: Apidae) Populations Assessed by PCR-RFLP. Biochemical Genetics 48: 326-341.

TAMURA, K., DUDLEY, J., NEI, M., KUMAR, S. (2007). Mega4: Molecular evolutionary genetics analysis (MEGA) software version 4.0. Molecular Biology and Evolution. 24: 1596-1599.

TEIXEIRA, L. V., BELLUSCI, S., MARQUES, M. D. (2002). Influência das condições de criação na atividade externa das forrageadoras de Frieseomelitta varia (Apidae, Meliponini). Anais do V Encontro Sobre Abelhas, Ribeirão Preto, SP. P. 317.

WEINLICH, R., FRANCISCO, F. O., ARIAS, M. C. (2004) Mitochondrial DNA restriction and genomic maps of seven species of Melipona (Apidae: Meliponini), Apidologie 35: 365-370. 
WIDMER, A., SCHMID-HEMPEL, P., ESTOUP, A., SCHOOLS, A. (1998). Population genetic structure and colonization history of Bombus terrestris (Hymenoptera: Apidae) from the Canary Islands and Madeira. Heredity 81: 563572.

WIDMER, A., SCHMID-HEMPEL, P. (1999). The population genetic structure of a large temperate pollinator species, Bombus pascuorum (Scopoli) (Hymenoptera: Apidae). Mol. Ecol. 8: 387-398.

WOLSTENHOLME, D. R. (1992). Animal mitochondrial DNA: Structure and evolution. In Mitochondrial Genomes (eds. D.R. Wolstenholme e K.W. Jeon), pp. 173-216, Academic Press, San Diego.

WRIGHT, S. (1969). The theory of gene frequencies. Chicago: The University. 511p.

ZAYED, A., PACKER, L. (2005). Complementary sex determination substantially increases extinction proneness of haplodiploid populations. PNAS 102: 1074210746. 


\section{Apêndices}

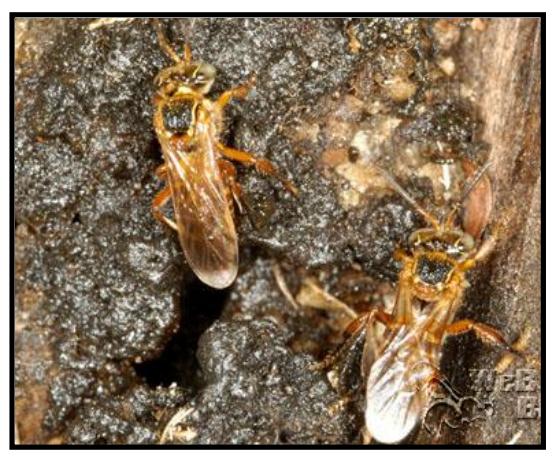




\section{Apêndice 1.}

Tabela 28: Padrões de corte gerados pela digestão enzimática das regiões mitocondriais amplificadas para $F$. varia (amostras do Campus USP e externas), $F$. trichocerata $\left(\boldsymbol{F} . t_{\text {. }}\right)$ e F.doederleini $(\boldsymbol{F} . \boldsymbol{d}$.). Os fragmentos estão codificados como presentes (1) ou ausentes (0). Os padrões de corte estão representados por letras. Nome e tamanho da região (pb), enzima usada na reação e grupo amostral estão apresentados. I- Ase I; II- Dra I; III-EcoR I; IV-Bcl I; V-EcoR V;VI$X b a$ I; VII- Rsa I; VIII- Hinf I; IX- Ssp I; Xa e Xb- Mbo I; XI- Pst I e XII- Cla I.

I

\begin{tabular}{|c|c|c|c|c|c|c|c|c|c|c|c|c|c|c|c|c|c|c|c|c|c|}
\hline \multicolumn{7}{|c|}{$[C O I I]-950 \mathrm{pb}-A s e \mathrm{I}$} & \multicolumn{6}{|c|}{$[N D 1 / 16 S]-800 \mathrm{pb}-$ Ase $\mathrm{I}$} & \multicolumn{9}{|c|}{$[C O I]-980 \mathrm{pb}-A s e \mathrm{I}$} \\
\hline \multirow[t]{2}{*}{ Fragmentos } & \multicolumn{2}{|c|}{$\begin{array}{c}\text { Campus } \\
\text { USP }\end{array}$} & \multicolumn{2}{|c|}{$\begin{array}{c}\text { Amostras } \\
\text { externas }\end{array}$} & \multirow{2}{*}{$\begin{array}{l}\text { F.t. } \\
\mathbf{A}\end{array}$} & \multirow{2}{*}{$\begin{array}{c}F . d . \\
\mathbf{C}\end{array}$} & \multirow[t]{2}{*}{ Fragmentos } & \multirow{2}{*}{$\begin{array}{c}\text { Campus } \\
\text { USP } \\
\text { A }\end{array}$} & \multicolumn{2}{|c|}{$\begin{array}{c}\text { Amostras } \\
\text { externas }\end{array}$} & \multirow{2}{*}{$\begin{array}{l}\text { F.t. } \\
\mathbf{A}\end{array}$} & \multirow{2}{*}{$\begin{array}{c}F . d . \\
\text { C }\end{array}$} & \multirow[t]{2}{*}{ Fragmentos } & \multirow{2}{*}{$\begin{array}{c}\text { Campus } \\
\text { USP } \\
\text { A }\end{array}$} & \multicolumn{4}{|c|}{ Amostras externas } & \multicolumn{2}{|c|}{ F.t. } & \multirow{2}{*}{$\begin{array}{c}F . d . \\
\mathbf{F}\end{array}$} \\
\hline & $\mathbf{A}$ & $\mathbf{B}$ & $\mathbf{A}$ & $\mathbf{B}$ & & & & & $\mathbf{A}$ & B & & & & & $\mathbf{A}$ & B & $\mathbf{C}$ & D & $\mathbf{A}$ & $\mathbf{E}$ & \\
\hline 320 & 1 & 0 & 1 & 0 & 1 & 1 & 400 & 1 & 1 & 1 & 1 & 1 & 600 & 0 & 0 & 0 & 0 & 0 & 0 & 1 & 1 \\
\hline 270 & 0 & 1 & 0 & 1 & 0 & 0 & 140 & 1 & 1 & 0 & 1 & 0 & 500 & 1 & 1 & 1 & 1 & 1 & 1 & 0 & 0 \\
\hline 240 & 0 & 0 & 0 & 0 & 0 & 1 & 105 & 1 & 1 & 1 & 1 & 1 & 180 & 0 & 0 & 0 & 0 & 0 & 0 & 0 & 1 \\
\hline 180 & 0 & 1 & 0 & 1 & 0 & 0 & 100 & 0 & 0 & 0 & 0 & 1 & 145 & 0 & 0 & 0 & 0 & 0 & 0 & 0 & 1 \\
\hline 155 & 1 & 1 & 1 & 1 & 1 & 0 & 98 & 0 & 0 & 1 & 0 & 0 & 130 & 1 & 1 & 1 & 1 & 1 & 1 & 1 & 0 \\
\hline 140 & 0 & 0 & 0 & 0 & 0 & 1 & 90 & 1 & 1 & 0 & 1 & 0 & 105 & 1 & 1 & 1 & 1 & 1 & 1 & 1 & 0 \\
\hline 130 & 0 & 0 & 0 & 0 & 0 & 1 & 80 & 0 & 0 & 0 & 0 & 1 & 90 & 1 & 1 & 0 & 1 & 1 & 1 & 0 & 0 \\
\hline 125 & 1 & 1 & 1 & 1 & 1 & 0 & 70 & 0 & 0 & 0 & 0 & 1 & 80 & 0 & 0 & 0 & 1 & 1 & 0 & 0 & 0 \\
\hline 115 & 1 & 0 & 1 & 0 & 1 & 0 & 60 & 1 & 1 & 1 & 1 & 1 & 75 & 0 & 0 & 1 & 0 & 1 & 0 & 1 & 0 \\
\hline 105 & 1 & 1 & 1 & 1 & 1 & 0 & & & & & & & 70 & 1 & 1 & 1 & 1 & 1 & 1 & 1 & 1 \\
\hline 85 & 1 & 1 & 1 & 1 & 1 & 0 & & & & & & & & & & & & & & & \\
\hline 50 & 0 & 1 & 0 & 1 & 0 & 0 & & & & & & & & & & & & & & & \\
\hline
\end{tabular}


II

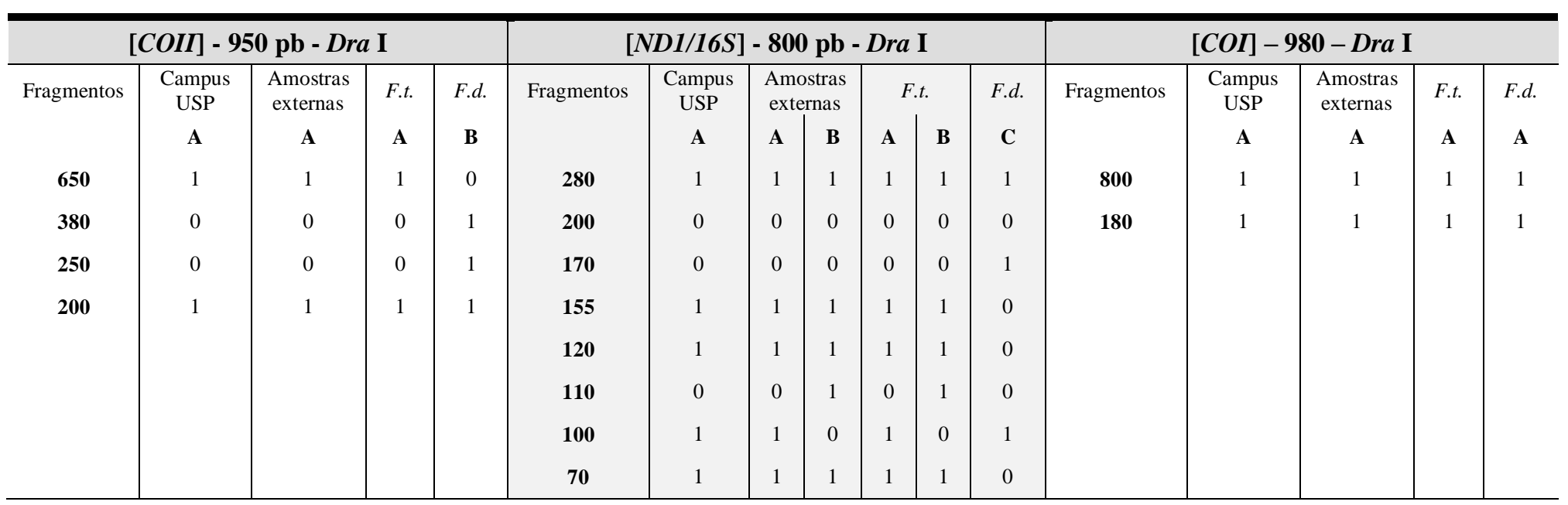

III

\begin{tabular}{c|c|c|c|c|c}
\hline \multicolumn{6}{c}{ [ATPase 6 e $8 /$ COIII - 1900 pb - Eco R I } \\
\hline Fragmentos & Campus USP & Amostras externas & F.t. & F.d. \\
& A & B & B & B & B \\
$\mathbf{1 9 0 0}$ & 1 & 0 & 0 & 0 & 0 \\
$\mathbf{1 8 0 0}$ & 0 & 1 & 1 & 1 & 1 \\
$\mathbf{1 0 0}$ & 0 & 1 & 1 & 1 & 1 \\
\hline
\end{tabular}

IV

\begin{tabular}{c|c|c|c|c}
\hline \multicolumn{5}{c}{$[\boldsymbol{C O}]-\mathbf{9 8 0} \mathbf{~ p b}-\boldsymbol{B c l} \mathbf{I}$} \\
\hline Fragmentos & Campus USP & Amostras externas & F.t. & F.d. \\
& $\mathbf{A}$ & $\mathbf{A}$ & $\mathbf{A}$ & $\mathbf{B}$ \\
$\mathbf{9 8 0}$ & 1 & 1 & 1 & 0 \\
$\mathbf{6 0 0}$ & 0 & 0 & 0 & 1 \\
$\mathbf{3 8 0}$ & 0 & 0 & 0 & 1 \\
\hline
\end{tabular}


V

\begin{tabular}{|c|c|c|c|c|c|c|c|c|c|c|}
\hline \multicolumn{6}{|c|}{ [ATPase 6 e 8/COIII] - 1900 pb - EcoR V } & \multicolumn{5}{|c|}{$[16 S / 12 S]-1800 \mathrm{pb}-E c o R \mathrm{~V}$} \\
\hline \multirow[t]{2}{*}{ Fragmentos } & \multicolumn{2}{|c|}{ Campus USP } & \multirow{2}{*}{$\begin{array}{c}\text { Amostras externas } \\
\mathbf{A}\end{array}$} & \multirow{2}{*}{$\begin{array}{c}\text { F.t. } \\
\mathbf{A}\end{array}$} & \multirow{2}{*}{$\begin{array}{c}F . d . \\
\mathbf{A}\end{array}$} & \multirow[t]{2}{*}{ Fragmentos } & \multirow{2}{*}{$\begin{array}{c}\text { Campus USP } \\
\mathbf{A}\end{array}$} & \multirow{2}{*}{$\begin{array}{c}\text { Amostras externas } \\
\mathbf{A}\end{array}$} & \multirow{2}{*}{$\begin{array}{c}\text { F.t. } \\
\text { A }\end{array}$} & \multirow{2}{*}{$\begin{array}{c}\text { F.d } \\
\mathbf{A}\end{array}$} \\
\hline & $\mathbf{A}$ & B & & & & & & & & \\
\hline 1250 & 1 & 0 & 1 & 1 & 1 & 1000 & 1 & 1 & 1 & 1 \\
\hline 1000 & 0 & 1 & 0 & 0 & 0 & 800 & 1 & 1 & 1 & 1 \\
\hline 900 & 0 & 1 & 0 & 0 & 0 & & & & & \\
\hline 550 & 1 & 0 & 1 & 1 & 1 & & & & & \\
\hline
\end{tabular}

VI

\begin{tabular}{c|c|c|c|c}
\hline \multicolumn{5}{c}{ [ATPase 6 e 8/COIII] - 1900 pb - Xba I } \\
\hline Fragmentos & Campus USP & Amostras externas & F.t. & F.d. \\
& A & A & A & B \\
$\mathbf{1 9 0 0}$ & 1 & 1 & 1 & 0 \\
$\mathbf{1 8 0 0}$ & 0 & 0 & 0 & 1 \\
$\mathbf{1 0 0}$ & 0 & 0 & 0 & 1 \\
\hline
\end{tabular}

\section{VII}

\begin{tabular}{|c|c|c|c|c|c|c|c|c|c|c|c|c|c|c|c|c|c|}
\hline \multicolumn{8}{|c|}{ [ATPase 6 e 8/COIII] - $1900 \mathrm{pb}-$ Rsa I } & \multicolumn{5}{|c|}{$[N D 1 / 16 S]-800 \mathrm{pb}-R s a \mathrm{I}$} & \multicolumn{5}{|c|}{$[16 S / 12 S]-1800 \mathrm{pb}-R s a \mathrm{I}$} \\
\hline \multirow[t]{2}{*}{ Fragmentos } & \multicolumn{3}{|c|}{ Campus USP } & \multirow{2}{*}{$\begin{array}{c}\text { Amostras externas } \\
\text { A }\end{array}$} & \multicolumn{2}{|c|}{ F.t. } & \multirow{2}{*}{$\begin{array}{c}F . d . \\
\mathbf{A}\end{array}$} & \multirow[t]{2}{*}{ Fragmentos } & \multirow{2}{*}{$\begin{array}{c}\text { Campus USP } \\
\text { A }\end{array}$} & \multirow{2}{*}{$\begin{array}{c}\text { Amostras externas } \\
\text { A }\end{array}$} & \multirow{2}{*}{$\begin{array}{l}\text { F.t. } \\
\text { A }\end{array}$} & \multirow{2}{*}{$\begin{array}{c}F . d . \\
\text { A }\end{array}$} & \multirow[t]{2}{*}{ Fragmentos } & \multirow{2}{*}{$\begin{array}{c}\text { Campus USP } \\
\mathbf{A}\end{array}$} & \multirow{2}{*}{$\begin{array}{c}\text { Amostras externas } \\
\text { A }\end{array}$} & \multirow{2}{*}{$\begin{array}{c}\text { F.t. } \\
\text { A }\end{array}$} & \multirow{2}{*}{$\begin{array}{c}F . d . \\
\mathbf{A}\end{array}$} \\
\hline & $\mathbf{A}$ & B & $\mathbf{C}$ & & $\mathbf{A}$ & $\mathbf{D}$ & & & & & & & & & & & \\
\hline 1900 & 1 & 0 & 0 & 1 & 1 & 0 & 1 & 550 & 1 & 1 & 1 & 1 & 600 & 1 & 1 & 1 & 1 \\
\hline 1300 & 0 & 0 & 0 & 0 & 0 & 1 & 0 & 250 & 1 & 1 & 1 & 1 & 450 & 1 & 1 & 1 & 1 \\
\hline 950 & 0 & 1 & 0 & 0 & 0 & 0 & 0 & & & & & & 400 & 1 & 1 & 1 & 1 \\
\hline 850 & 0 & 1 & 0 & 0 & 0 & 0 & 0 & & & & & & 300 & 1 & 1 & 1 & 1 \\
\hline 600 & 0 & 0 & 1 & 0 & 0 & 1 & 0 & & & & & & & & & & \\
\hline 500 & 0 & 0 & 1 & 0 & 0 & 0 & 0 & & & & & & & & & & \\
\hline 450 & 0 & 0 & 1 & 0 & 0 & 0 & 0 & & & & & & & & & & \\
\hline 400 & 0 & 0 & 0 & 0 & 0 & 0 & 0 & & & & & & & & & & \\
\hline 300 & 0 & 0 & 1 & 0 & 0 & 0 & 0 & & & & & & & & & & \\
\hline
\end{tabular}


VIII

\begin{tabular}{|c|c|c|c|c|c|c|c|c|c|c|c|c|c|c|c|c|c|c|c|c|}
\hline \multicolumn{5}{|c|}{$[C O I I]-950 \mathrm{pb}-\operatorname{Hinf} \mathrm{I}$} & \multicolumn{6}{|c|}{ [ATPase 6 e $8 / C O I I I]-1900$ pb - Hinf I } & \multicolumn{5}{|c|}{$[C O I]-980 \mathrm{pb}-\operatorname{Hinf} \mathrm{I}$} & \multicolumn{5}{|c|}{$[N D 1 / 16 S]-800 \mathrm{pb}-\operatorname{Hinf} \mathrm{I}$} \\
\hline \multirow[t]{2}{*}{ Fragmentos } & $\begin{array}{l}\text { Campus } \\
\text { USP }\end{array}$ & $\begin{array}{c}\text { Amostras } \\
\text { externas }\end{array}$ & F.t. & F.d. & Fragmentos & $\begin{array}{c}\text { Campus } \\
\text { USP }\end{array}$ & $\begin{array}{l}\text { Amostras } \\
\text { externas }\end{array}$ & $F$ & & F.d. & Fragmentos & $\begin{array}{c}\text { Campus } \\
\text { USP }\end{array}$ & $\begin{array}{c}\text { Amostras } \\
\text { externas }\end{array}$ & & & Fragmentos & $\begin{array}{c}\text { Campus } \\
\text { USP }\end{array}$ & $\begin{array}{c}\text { Amostras } \\
\text { externas }\end{array}$ & F.t. & \\
\hline & $\mathbf{A}$ & $\mathbf{A}$ & $\mathbf{A}$ & B & & $\mathbf{A}$ & $\mathbf{A}$ & $\mathbf{A}$ & B & $\mathbf{A}$ & & $\mathbf{A}$ & $\mathbf{A}$ & $\mathbf{A}$ & $\mathbf{A}$ & & A & $\mathbf{A}$ & $\mathbf{A}$ & B \\
\hline 600 & 1 & 1 & 1 & 0 & 1100 & 1 & 1 & 1 & 0 & 1 & 500 & 1 & 1 & 1 & 1 & 800 & 1 & 1 & 1 & 1 \\
\hline 400 & 0 & 0 & 0 & 1 & 800 & 1 & 1 & 1 & 1 & 1 & 480 & 1 & 1 & 1 & 1 & 600 & 0 & 0 & 0 & 0 \\
\hline 350 & 1 & 1 & 1 & 1 & 700 & 0 & 0 & 0 & 1 & 0 & & & & & & 200 & 0 & 0 & 0 & 0 \\
\hline 200 & 0 & 0 & 0 & 1 & 400 & 0 & 0 & 0 & 1 & 0 & & & & & & & & & & \\
\hline
\end{tabular}

\section{IX}

\begin{tabular}{|c|c|c|c|c|c|c|c|c|c|c|c|c|c|c|c|c|c|c|c|}
\hline \multicolumn{6}{|c|}{$[C O I I]-950 \mathrm{pb}$ - Ssp I } & \multicolumn{9}{|c|}{$[N D 1 / 16 S]-800 \mathrm{pb}-S s p$ I } & \multicolumn{5}{|c|}{$[C O I]-980 \mathrm{pb}-\operatorname{Ssp} \mathrm{I}$} \\
\hline \multirow[t]{2}{*}{ Fragmentos } & \multirow{2}{*}{$\begin{array}{c}\text { Campus USP } \\
\text { A }\end{array}$} & \multirow{2}{*}{$\begin{array}{c}\text { Amostras externas } \\
\text { A }\end{array}$} & \multicolumn{2}{|c|}{ F.t. } & \multirow{2}{*}{$\begin{array}{l}F . d . \\
\mathbf{C}\end{array}$} & \multirow[t]{2}{*}{ Fragmentos } & \multicolumn{2}{|c|}{ Campus USP } & \multicolumn{3}{|c|}{ Amostras externas } & \multicolumn{2}{|c|}{ F.t. } & \multirow{2}{*}{$\begin{array}{l}F . d . \\
\mathbf{E}\end{array}$} & \multirow[t]{2}{*}{ Fragmentos } & \multirow{2}{*}{$\begin{array}{c}\text { Campus USP } \\
\text { A }\end{array}$} & \multirow{2}{*}{$\begin{array}{c}\text { Amostras externas } \\
\text { A }\end{array}$} & \multirow{2}{*}{$\begin{array}{l}\text { F.t. } \\
\text { A }\end{array}$} & \multirow{2}{*}{$\begin{array}{c}\text { F.d. } \\
\text { B }\end{array}$} \\
\hline & & & $\mathbf{A}$ & B & & & $\mathbf{A}$ & B & $\mathbf{A}$ & B & $\mathbf{C}$ & $\mathbf{A}$ & $\mathbf{D}$ & & & & & & \\
\hline 420 & 0 & 0 & 0 & 1 & 0 & 400 & 0 & 1 & 0 & 1 & 0 & 0 & 0 & 0 & 550 & 1 & 1 & 1 & 0 \\
\hline 330 & 1 & 1 & 1 & 0 & 1 & 330 & 0 & 0 & 0 & 0 & 0 & 0 & 0 & 1 & 300 & 0 & 0 & 0 & 1 \\
\hline 250 & 1 & 1 & 1 & 1 & 1 & 270 & 1 & 1 & 1 & 1 & 1 & 1 & 1 & 1 & 200 & 1 & 1 & 1 & 1 \\
\hline 225 & 0 & 0 & 0 & 1 & 0 & 220 & 1 & 0 & 1 & 0 & 1 & 1 & 1 & 0 & 180 & 1 & 1 & 1 & 0 \\
\hline 220 & 1 & 1 & 1 & 0 & 0 & 150 & 0 & 0 & 0 & 0 & 0 & 0 & 1 & 0 & & & & & \\
\hline 160 & 0 & 0 & 0 & 0 & 1 & 140 & 0 & 0 & 0 & 0 & 1 & 0 & 0 & 0 & & & & & \\
\hline 100 & 0 & 0 & 0 & 0 & 1 & 120 & 0 & 1 & 0 & 1 & 0 & 0 & 1 & 0 & & & & & \\
\hline 90 & 0 & 0 & 0 & 0 & 1 & 105 & 1 & 0 & 1 & 0 & 0 & 1 & 0 & 0 & & & & & \\
\hline 85 & 1 & 1 & 1 & 0 & 0 & 70 & 1 & 0 & 1 & 0 & 0 & 1 & 0 & 0 & & & & & \\
\hline 75 & 0 & 0 & 0 & 1 & 0 & 60 & 1 & 0 & 1 & 0 & 0 & 1 & 0 & 0 & & & & & \\
\hline 70 & 1 & 1 & 1 & 0 & 0 & & & & & & & & & & & & & & \\
\hline
\end{tabular}


X a

\begin{tabular}{|c|c|c|c|c|c|c|c|c|c|c|c|c|c|c|c|c|c|c|c|c|c|c|}
\hline \multicolumn{5}{|c|}{$[C O I I]-950 \mathrm{pb}-M b o \mathrm{I}$} & \multicolumn{8}{|c|}{ [ATPase 6 e 8/COIII] - 1900 pb - Mbo I } & \multicolumn{5}{|c|}{$[N D 1 / 16 S]-800 \mathrm{pb}-$ Mbo I } & \multicolumn{5}{|c|}{$[C O I]-980 \mathrm{pb}-\quad M b o$ I } \\
\hline \multirow[t]{2}{*}{ Fragmentos } & \multirow{2}{*}{$\begin{array}{c}\text { Campus } \\
\text { USP } \\
\mathbf{A}\end{array}$} & \multirow{2}{*}{$\begin{array}{c}\text { Amostras } \\
\text { externas } \\
\mathbf{A}\end{array}$} & \multirow{2}{*}{$\begin{array}{l}\text { F.t. } \\
\mathbf{A}\end{array}$} & \multirow{2}{*}{$\begin{array}{c}F . d . \\
\text { B }\end{array}$} & \multirow[t]{2}{*}{ Fragmentos } & \multicolumn{3}{|c|}{$\begin{array}{c}\text { Campus } \\
\text { USP }\end{array}$} & \multicolumn{2}{|c|}{$\begin{array}{l}\text { Amostras } \\
\text { externas }\end{array}$} & \multirow{2}{*}{$\begin{array}{l}\text { F.t. } \\
\mathbf{A}\end{array}$} & \multirow{2}{*}{$\begin{array}{c}F . d \\
\mathbf{E}\end{array}$} & \multirow[t]{2}{*}{ Fragmentos } & \multirow{2}{*}{$\begin{array}{c}\text { Campus } \\
\text { USP } \\
\text { A }\end{array}$} & \multirow{2}{*}{$\begin{array}{c}\text { Amostras } \\
\text { externas } \\
\mathbf{A}\end{array}$} & \multirow{2}{*}{$\begin{array}{l}\text { F.t. } \\
\text { A }\end{array}$} & \multirow{2}{*}{$\begin{array}{c}F . d . \\
\text { B }\end{array}$} & \multirow[t]{2}{*}{ Fragmentos } & \multirow{2}{*}{$\begin{array}{c}\text { Campus } \\
\text { USP } \\
\text { A }\end{array}$} & \multirow{2}{*}{$\begin{array}{c}\text { Amostras } \\
\text { externas } \\
\mathbf{A}\end{array}$} & \multirow{2}{*}{$\begin{array}{c}\text { F.t. } \\
\mathbf{A}\end{array}$} & \multirow{2}{*}{$\begin{array}{r}F . d \\
\text { B }\end{array}$} \\
\hline & & & & & & $\mathbf{A}$ & B & $\mathbf{C}$ & $\mathbf{A}$ & $\mathbf{D}$ & & & & & & & & & & & & \\
\hline 950 & 0 & 0 & 0 & 1 & 1500 & 0 & 1 & 0 & 0 & 0 & 0 & 0 & 800 & 0 & 0 & 0 & 1 & 980 & 0 & 0 & 0 & 1 \\
\hline 640 & 1 & 1 & 1 & 0 & 1300 & 1 & 0 & 0 & 1 & 0 & 1 & 0 & 390 & 1 & 1 & 1 & 0 & 600 & 1 & 1 & 1 & 0 \\
\hline 310 & 1 & 1 & 1 & 0 & 1200 & 0 & 0 & 0 & 0 & 1 & 0 & 0 & 400 & 1 & 1 & 1 & 0 & 380 & 1 & 1 & 1 & 0 \\
\hline & & & & & 1000 & 0 & 0 & 0 & 0 & 0 & 0 & 1 & & & & & & & & & & \\
\hline & & & & & 900 & 0 & 0 & 1 & 0 & 0 & 0 & 0 & & & & & & & & & & \\
\hline & & & & & 850 & 0 & 0 & 1 & 0 & 0 & 0 & 0 & & & & & & & & & & \\
\hline & & & & & 400 & 1 & 1 & 0 & 1 & 1 & 1 & 1 & & & & & & & & & & \\
\hline & & & & & 300 & 0 & 0 & 0 & 0 & 0 & 0 & 1 & & & & & & & & & & \\
\hline & & & & & 200 & 1 & 0 & 0 & 1 & 1 & 1 & 1 & & & & & & & & & & \\
\hline & & & & & 100 & 0 & 0 & 0 & 0 & 1 & 0 & 0 & & & & & & & & & & \\
\hline
\end{tabular}

X b

\begin{tabular}{c|c|c|c|c}
\hline \multicolumn{5}{|c}{$[16 \mathrm{~S} / 12 S]-1800 \mathbf{p b}-$ Mbo I } \\
\hline Fragmentos & Campus USP & Amostras externas & F.t. & F.d. \\
& A & A & A & B \\
$\mathbf{1 0 0 0}$ & 0 & 0 & 0 & 1 \\
$\mathbf{9 0 0}$ & 1 & 1 & 1 & 0 \\
$\mathbf{8 0 0}$ & 1 & 1 & 1 & 1 \\
\hline
\end{tabular}


XI

\begin{tabular}{|c|c|c|c|c|c|c|c|c|c|}
\hline \multicolumn{5}{|c|}{$[N D 1 / 16 S]-800 \mathrm{pb}-$ Pst I } & \multicolumn{5}{|c|}{$[16 S / 12 S]-1800 \mathrm{pb}-$ Pst I } \\
\hline Fragmentos & $\begin{array}{l}\text { Campus } \\
\text { USP }\end{array}$ & $\begin{array}{c}\text { Amostras } \\
\text { externas }\end{array}$ & F.t. & F.d. & Fragmentos & $\begin{array}{l}\text { Campus } \\
\text { USP }\end{array}$ & $\begin{array}{l}\text { Amostras } \\
\text { externas }\end{array}$ & F.t. & F.d. \\
\hline & A & B & $\mathbf{B}$ & $\mathbf{B}$ & & $\mathbf{A}$ & $\mathbf{A}$ & A & $\mathbf{A}$ \\
\hline 800 & 1 & 0 & 0 & 0 & 1300 & 1 & 1 & 1 & 1 \\
\hline 700 & 0 & 1 & 1 & 1 & 500 & 1 & 1 & 1 & 1 \\
\hline 100 & 0 & 1 & 1 & 1 & & & & & \\
\hline
\end{tabular}

\section{XII}

\begin{tabular}{|c|c|c|c|c|c|c|c|c|c|c|}
\hline \multicolumn{5}{|c|}{$[C O I I]-950 \mathrm{pb}-C l a \mathrm{I}$} & \multicolumn{6}{|c|}{ [ATPase 6 e 8/COIII] - 1900 pb - Cla I } \\
\hline \multirow[t]{2}{*}{ Fragmentos } & \multirow{2}{*}{$\begin{array}{c}\text { Campus } \\
\text { USP } \\
\text { A }\end{array}$} & \multirow{2}{*}{$\begin{array}{c}\text { Amostras } \\
\text { externas } \\
\mathbf{A}\end{array}$} & \multirow{2}{*}{$\begin{array}{l}\text { F.t. } \\
\mathbf{A}\end{array}$} & \multirow{2}{*}{$\begin{array}{c}F . d . \\
\mathbf{A}\end{array}$} & \multirow[t]{2}{*}{ Fragmentos } & \multicolumn{2}{|c|}{ Campus USP } & \multirow{2}{*}{$\begin{array}{c}\text { Amostras } \\
\text { externas } \\
\text { A }\end{array}$} & \multirow{2}{*}{$\begin{array}{c}\text { F.t. } \\
\mathbf{A}\end{array}$} & \multirow{2}{*}{$\begin{array}{c}F . d . \\
\mathbf{A}\end{array}$} \\
\hline & & & & & & $\mathbf{A}$ & B & & & \\
\hline 800 & 1 & 1 & 1 & 1 & 1900 & 0 & 1 & 0 & 0 & 0 \\
\hline 150 & 1 & 1 & 1 & 1 & 1400 & 1 & 0 & 1 & 1 & 1 \\
\hline & & & & & 500 & 1 & 0 & 1 & 1 & 1 \\
\hline
\end{tabular}




\section{Apêndice 2.}

Tabela 29: Exemplo de como foram codificados os padrões de corte provenientes da digestão enzimática das regiões mitocondriais amplificadas para $F$. varia, $F$. trichocerata e $F$. doederleini (Ex. Padrão A, B, C). São Apresentados apenas os resultados de duas das enzimas usadas: I - Hinf I; II - EcoR V. Fragmentos gerados nas digestões de cada região e a codificação de suas combinações considerando todas as regiões que apresentaram sítio de restrição para uma dada enzimas são mostrados.

I

\begin{tabular}{|c|c|c|c|c|c|c|c|c|c|c|c|c|c|c|c|c|}
\hline \multirow{2}{*}{ Amostra } & \multicolumn{4}{|c|}{$[C O I I]-950 \mathrm{pb}$} & \multicolumn{4}{|c|}{ [ATPase 6 e $8 / C O I I I]-1900 \mathrm{pb}$} & \multicolumn{3}{|c|}{$[N D 1 / 16 S]-800 \mathrm{pb}$} & \multicolumn{4}{|c|}{$[C O I]-980 \mathrm{pb}$} & \multirow{2}{*}{ Padrão } \\
\hline & 600 & 400 & 350 & 200 & 1100 & 800 & 700 & 400 & 800 & 600 & 250 & 550 & 300 & 200 & 180 & \\
\hline 1 & 1 & 0 & 1 & 0 & 1 & 1 & 0 & 0 & 1 & 0 & 0 & 1 & 0 & 1 & 1 & $\mathbf{A}$ \\
\hline 2 & 1 & 0 & 1 & 0 & 0 & 1 & 1 & 1 & 1 & 0 & 0 & 1 & 0 & 1 & 1 & B \\
\hline 3 & 0 & 1 & 1 & 1 & 1 & 1 & 0 & 0 & 0 & 1 & 1 & 0 & 1 & 1 & 0 & $\mathbf{C}$ \\
\hline
\end{tabular}

II

\begin{tabular}{|c|c|c|c|c|c|c|c|}
\hline \multirow{2}{*}{ Amostra } & \multicolumn{4}{|c|}{ [ATPase 6 e 8/COIII] - 1900 pb } & \multicolumn{2}{|c|}{$[16 S / 12 S]-1800 \mathrm{pb}$} & \multirow[t]{2}{*}{ Padrão } \\
\hline & 1250 & 1000 & 900 & 550 & 1000 & 800 & \\
\hline 1 & 1 & 0 & 0 & 1 & 1 & 1 & $\mathbf{A}$ \\
\hline 2 & 0 & 1 & 1 & 0 & 1 & 1 & B \\
\hline
\end{tabular}


Tabela 30: Haplótipos compostos formados pela combinação dos padrões de corte gerados pelas digestões enzimáticas das regiões mitocondriais amplificadas para as amostras de $F$. varia, F. trichocerata e $F$. doederleini.

\begin{tabular}{|c|c|c|c|c|c|c|c|c|c|c|c|c|}
\hline Haplótipo & Ase I & Bcl I & Cla I & Dra I & EcoR I & $E c o R$ V & Hinf I I & Mbo I & Pst I & Rsa I & Ssp I & $X b a \mathbf{I}$ \\
\hline Hr1 & A & A & A & A & A & A & A & $\mathrm{A}$ & A & A & A & A \\
\hline Hr2 & A & A & A & A & A & A & A & A & A & A & B & A \\
\hline Hr3 & A & A & A & A & B & A & A & A & A & A & A & A \\
\hline Hr4 & A & A & A & A & B & A & A & A & B & A & A & A \\
\hline Hr5 & A & A & B & A & A & B & A & C & A & C & A & A \\
\hline Hr6 & B & A & A & A & B & A & A & A & B & A & A & A \\
\hline Hr7 & C & A & A & A & A & A & A & A & A & A & A & A \\
\hline Hr8 & $\mathrm{C}$ & A & A & A & A & A & A & B & A & B & A & A \\
\hline Hr9 & C & A & A & A & B & A & A & B & A & A & A & A \\
\hline Hr10 & C & A & A & B & B & A & A & A & B & A & D & A \\
\hline Hr11 & C & A & B & A & A & B & A & C & A & C & A & A \\
\hline Hr12 & $\mathrm{C}$ & A & B & A & B & B & A & $\mathrm{C}$ & A & $\mathrm{C}$ & A & A \\
\hline Hr13 & D & A & A & A & B & A & A & A & B & A & A & A \\
\hline Hr14 & D & A & A & B & B & A & A & A & B & A & D & A \\
\hline Hr15 & D & A & A & B & B & A & A & D & B & A & B & A \\
\hline Hr16 & D & A & A & B & B & A & A & D & B & A & C & A \\
\hline Hr17 & E & A & A & A & B & A & A & A & B & A & A & A \\
\hline Hr18 & F & A & A & B & B & A & A & A & B & A & D & A \\
\hline Hr19 & $\mathrm{F}$ & A & A & B & B & A & B & A & B & D & E & A \\
\hline Hr20 & G & A & A & A & B & A & A & A & B & A & A & A \\
\hline Hr21 & $\mathrm{H}$ & B & A & $\mathrm{C}$ & B & A & $\mathrm{C}$ & E & B & A & $\mathrm{F}$ & A \\
\hline
\end{tabular}


Apêndice 3.

Tabela 31: Alelos encontrados para cada loco e suas frequências totais e em cada um dos grupos de amostras de $F$. varia, $F$ trichocerata $(F . t$.) e $F$. doederleini $(F$. d.). Também é mostrado o grupo amostral ao qual o alelo está restrito, quando for o caso.

\section{I - Friv14}

F. varia

\begin{tabular}{|c|c|c|c|c|c|c|c|c|c|c|}
\hline \multirow[b]{3}{*}{ Alelo } & \multirow[b]{3}{*}{ Tamanho } & \multicolumn{5}{|c|}{ F. varia } & \multirow[b]{3}{*}{ F.t. } & \multirow[b]{3}{*}{ F.d. } & \multirow[b]{3}{*}{ Total } & \multirow[b]{3}{*}{ Privativo } \\
\hline & & \multirow[b]{2}{*}{ Campus USP } & \multicolumn{4}{|c|}{ Amostras externas ao campus } & & & & \\
\hline & & & GO-MT-MG & SP & MT & MG & & & & \\
\hline 1 & 163 & 0,03 & 0,00 & 0,00 & 0,00 & 0,00 & 0,00 & 0,00 & 0,01 & Campus USP \\
\hline 2 & 171 & 0,00 & 0,00 & 0,00 & 0,00 & 0,00 & 0,05 & 0,00 & 0,01 & F.t. \\
\hline 3 & 172 & 0,00 & 0,00 & 0,00 & 0,00 & 0,00 & 0,02 & 0,00 & 0,00 & F.t. \\
\hline 4 & 173 & 0,00 & 0,00 & 0,00 & 0,00 & 0,00 & 0,03 & 0,00 & 0,01 & F.t. \\
\hline 5 & 174 & 0,00 & 0,00 & 0,00 & 0,25 & 0,00 & 0,02 & 0,50 & 0,02 & \\
\hline 6 & 175 & 0,02 & 0,00 & 0,00 & 0,00 & 0,00 & 0,00 & 0,00 & 0,00 & Campus USP \\
\hline 7 & 177 & 0,03 & 0,00 & 0,00 & 0,00 & 0,00 & 0,00 & 0,00 & 0,01 & Campus USP \\
\hline 8 & 178 & 0,08 & 0,00 & 0,04 & 0,00 & 0,00 & 0,12 & 0,00 & 0,06 & \\
\hline 9 & 179 & 0,00 & 0,03 & 0,00 & 0,00 & 0,00 & 0,02 & 0,00 & 0,01 & \\
\hline 10 & 180 & 0,18 & 0,47 & 0,31 & 0,00 & 0,25 & 0,20 & 0,00 & 0,24 & \\
\hline 11 & 182 & 0,11 & 0,17 & 0,15 & 0,25 & 0,33 & 0,00 & 0,17 & 0,11 & \\
\hline 12 & 184 & 0,11 & 0,13 & 0,00 & 0,25 & 0,00 & 0,02 & 0,00 & 0,06 & \\
\hline 13 & 186 & 0,03 & 0,00 & 0,00 & 0,00 & 0,00 & 0,05 & 0,33 & 0,03 & \\
\hline 14 & 188 & 0,23 & 0,03 & 0,04 & 0,00 & 0,00 & 0,08 & 0,00 & 0,11 & \\
\hline 15 & 190 & 0,03 & 0,00 & 0,00 & 0,00 & 0,00 & 0,17 & 0,00 & 0,06 & \\
\hline 16 & 192 & 0,02 & 0,00 & 0,00 & 0,00 & 0,00 & 0,07 & 0,00 & 0,02 & \\
\hline 17 & 194 & 0,02 & 0,00 & 0,00 & 0,00 & 0,00 & 0,02 & 0,00 & 0,01 & \\
\hline 18 & 196 & 0,03 & 0,03 & 0,00 & 0,25 & 0,17 & 0,10 & 0,00 & 0,06 & \\
\hline 19 & 198 & 0,02 & 0,00 & 0,00 & 0,00 & 0,00 & 0,03 & 0,00 & 0,01 & \\
\hline 20 & 200 & 0,00 & 0,07 & 0,00 & 0,00 & 0,00 & 0,02 & 0,00 & 0,01 & \\
\hline 21 & 202 & 0,00 & 0,03 & 0,04 & 0,00 & 0,00 & 0,00 & 0,00 & 0,01 & \\
\hline 22 & 203 & 0,02 & 0,00 & 0,12 & 0,00 & 0,00 & 0,00 & 0,00 & 0,02 & \\
\hline 23 & 204 & 0,00 & 0,03 & 0,08 & 0,00 & 0,08 & 0,00 & 0,00 & 0,02 & \\
\hline 24 & 205 & 0,06 & 0,00 & 0,23 & 0,00 & 0,08 & 0,00 & 0,00 & 0,05 & \\
\hline 25 & 206 & 0,02 & 0,00 & 0,00 & 0,00 & 0,00 & 0,00 & 0,00 & 0,00 & Campus USP \\
\hline 26 & 207 & 0,00 & 0,00 & 0,00 & 0,00 & 0,08 & 0,00 & 0,00 & 0,00 & MG \\
\hline & Total & 33 & 15 & 13 & 2 & 6 & 30 & 3 & 102 & \\
\hline
\end{tabular}




\section{II - Friv15}

\section{F. varia}

Amostras externas ao campus

\begin{tabular}{|c|c|c|c|c|c|c|c|c|c|c|}
\hline Alelo & Tamanho & Campus USP & GO-MT-MG & SP & MT & MG & F.t. & F. $d$. & Total & Privativo \\
\hline 1 & 150 & 0,03 & 0,50 & 0,04 & 0,00 & 0,00 & 0,00 & 0,00 & 0,08 & \\
\hline 2 & 156 & 0,00 & 0,00 & 0,00 & 0,00 & 0,00 & 0,04 & 0,33 & 0,02 & \\
\hline 3 & 160 & 0,05 & 0,00 & 0,00 & 0,00 & 0,00 & 0,00 & 0,00 & 0,02 & Campus USP \\
\hline 4 & 162 & 0,00 & 0,00 & 0,00 & 0,00 & 0,00 & 0,00 & 0,17 & 0,01 & F.d. \\
\hline 5 & 166 & 0,00 & 0,00 & 0,00 & 0,25 & 0,00 & 0,00 & 0,00 & 0,01 & MT \\
\hline 6 & 168 & 0,00 & 0,00 & 0,00 & 0,00 & 0,00 & 0,05 & 0,00 & 0,02 & F.t. \\
\hline 7 & 170 & 0,00 & 0,00 & 0,00 & 0,00 & 0,00 & 0,07 & 0,00 & 0,02 & F.t. \\
\hline 8 & 172 & 0,00 & 0,08 & 0,00 & 0,00 & 0,00 & 0,21 & 0,00 & 0,07 & \\
\hline 9 & 174 & 0,00 & 0,04 & 0,00 & 0,25 & 0,08 & 0,04 & 0,00 & 0,03 & \\
\hline 10 & 175 & 0,00 & 0,00 & 0,00 & 0,00 & 0,00 & 0,02 & 0,00 & 0,01 & F.t. \\
\hline 11 & 176 & 0,23 & 0,15 & 0,63 & 0,00 & 0,50 & 0,20 & 0,00 & 0,27 & \\
\hline 12 & 177 & 0,00 & 0,00 & 0,00 & 0,00 & 0,08 & 0,04 & 0,00 & 0,02 & \\
\hline 13 & 178 & 0,23 & 0,12 & 0,21 & 0,00 & 0,33 & 0,00 & 0,00 & 0,14 & \\
\hline 14 & 180 & 0,27 & 0,00 & 0,13 & 0,00 & 0,00 & 0,02 & 0,00 & 0,11 & \\
\hline 15 & 181 & 0,00 & 0,00 & 0,00 & 0,00 & 0,00 & 0,04 & 0,00 & 0,01 & F.t. \\
\hline 16 & 182 & 0,19 & 0,08 & 0,00 & 0,25 & 0,00 & 0,02 & 0,33 & 0,09 & \\
\hline 17 & 183 & 0,00 & 0,00 & 0,00 & 0,00 & 0,00 & 0,14 & 0,17 & 0,05 & \\
\hline 18 & 184 & 0,00 & 0,00 & 0,00 & 0,25 & 0,00 & 0,07 & 0,00 & 0,03 & \\
\hline 19 & 207 & 0,00 & 0,00 & 0,00 & 0,00 & 0,00 & 0,02 & 0,00 & 0,01 & F.t. \\
\hline 20 & 215 & 0,00 & 0,00 & 0,00 & 0,00 & 0,00 & 0,04 & 0,00 & 0,01 & F.t. \\
\hline 21 & 217 & 0,00 & 0,04 & 0,00 & 0,00 & 0,00 & 0,00 & 0,00 & 0,01 & GO-MT-MG \\
\hline \multicolumn{2}{|r|}{ Total } & 32 & 13 & 12 & 2 & 6 & 28 & 3 & 96 & \\
\hline
\end{tabular}




\section{III - Friv16}

F. varia

Amostras externas ao campus

\begin{tabular}{cc|cccccccccc} 
Alelo & Tamanho & Campus USP & GO-MT-MG & SP & MT & MG & $\boldsymbol{F} . \boldsymbol{t}$. & $\boldsymbol{F} . \boldsymbol{d}$. & Total & Privativo \\
\hline 1 & 164 & 0,00 & 0,00 & 0,00 & 0,00 & 0,00 & 0,00 & 0,50 & 0,01 & $F . d$. \\
2 & 165 & 0,00 & 0,00 & 0,00 & 0,00 & 0,00 & 0,00 & 0,50 & 0,01 & $F . d$. \\
3 & 179 & 0,00 & 0,00 & 0,00 & 0,00 & 0,00 & 0,03 & 0,00 & 0,01 & $F . t$. \\
4 & 183 & 0,00 & 0,07 & 0,00 & 0,00 & 0,00 & 0,00 & 0,00 & 0,01 & GO-MT-MG \\
5 & 187 & 0,11 & 0,00 & 0,04 & 0,00 & 0,00 & 0,00 & 0,00 & 0,04 & \\
6 & 189 & 0,02 & 0,10 & 0,04 & 0,00 & 0,17 & 0,02 & 0,00 & 0,04 & \\
7 & 191 & 0,20 & 0,00 & 0,08 & 0,25 & 0,17 & 0,05 & 0,00 & 0,10 & \\
8 & 192 & 0,20 & 0,07 & 0,00 & 0,00 & 0,00 & 0,23 & 0,00 & 0,14 & \\
9 & 194 & 0,41 & 0,30 & 0,75 & 0,25 & 0,00 & 0,13 & 0,00 & 0,31 & \\
10 & 196 & 0,07 & 0,27 & 0,08 & 0,00 & 0,58 & 0,20 & 0,00 & 0,17 & \\
11 & 198 & 0,00 & 0,00 & 0,00 & 0,25 & 0,08 & 0,13 & 0,00 & 0,05 & \\
12 & 200 & 0,00 & 0,03 & 0,00 & 0,00 & 0,00 & 0,00 & 0,00 & 0,01 & GO-MT-MG \\
13 & 202 & 0,00 & 0,07 & 0,00 & 0,00 & 0,00 & 0,00 & 0,00 & 0,01 & GO-MT-MG \\
14 & 204 & 0,00 & 0,10 & 0,00 & 0,00 & 0,00 & 0,07 & 0,00 & 0,04 & \\
15 & 206 & 0,00 & 0,00 & 0,00 & 0,00 & 0,00 & 0,02 & 0,00 & 0,01 & F.t. \\
16 & 208 & 0,00 & 0,00 & 0,00 & 0,00 & 0,00 & 0,02 & 0,00 & 0,01 & F.t. \\
17 & 211 & 0,00 & 0,00 & 0,00 & 0,00 & 0,00 & 0,02 & 0,00 & 0,01 & F.t. \\
18 & 212 & 0,00 & 0,00 & 0,00 & 0,25 & 0,00 & 0,03 & 0,00 & 0,02 &
\end{tabular}




\section{IV - Friv18}

\begin{tabular}{|c|c|c|c|c|c|c|c|c|c|c|}
\hline \multirow[b]{3}{*}{ Alelo } & \multirow[b]{3}{*}{ Tamanho } & \multicolumn{5}{|c|}{ F. varia } & \multirow[b]{3}{*}{ F.t. } & \multirow[b]{3}{*}{ F. $d$. } & \multirow[b]{3}{*}{ Total } & \multirow[b]{3}{*}{ Privativo } \\
\hline & & \multirow[b]{2}{*}{ Campus USP } & \multicolumn{4}{|c|}{ Amostras externas ao campus } & & & & \\
\hline & & & GO-MT-MG & SP & MT & MG & & & & \\
\hline 1 & 185 & 0,16 & 0,00 & 0,00 & 0,00 & 0,00 & 0,10 & 0,00 & 0,08 & \\
\hline 2 & 186 & 0,03 & 0,00 & 0,00 & 0,00 & 0,00 & 0,00 & 0,00 & 0,01 & Campus-USP \\
\hline 3 & 187 & 0,00 & 0,00 & 0,00 & 0,00 & 0,00 & 0,10 & 0,00 & 0,03 & F.t. \\
\hline 4 & 188 & 0,00 & 0,00 & 0,00 & 0,00 & 0,00 & 0,02 & 0,00 & 0,01 & F.t. \\
\hline 5 & 190 & 0,00 & 0,00 & 0,00 & 0,00 & 0,00 & 0,00 & 0,33 & 0,01 & F.d. \\
\hline 6 & 192 & 0,02 & 0,00 & 0,08 & 0,25 & 0,08 & 0,05 & 0,67 & 0,06 & \\
\hline 7 & 194 & 0,14 & 0,00 & 0,04 & 0,25 & 0,00 & 0,00 & 0,00 & 0,06 & \\
\hline 8 & 195 & 0,00 & 0,00 & 0,00 & 0,00 & 0,00 & 0,02 & 0,00 & 0,01 & F.t. \\
\hline 9 & 196 & 0,00 & 0,03 & 0,00 & 0,00 & 0,00 & 0,22 & 0,00 & 0,07 & \\
\hline 10 & 198 & 0,03 & 0,00 & 0,00 & 0,00 & 0,33 & 0,07 & 0,00 & 0,05 & \\
\hline 11 & 200 & 0,05 & 0,00 & 0,04 & 0,00 & 0,00 & 0,17 & 0,00 & 0,07 & \\
\hline 12 & 201 & 0,00 & 0,00 & 0,00 & 0,00 & 0,00 & 0,02 & 0,00 & 0,01 & F.t. \\
\hline 13 & 202 & 0,00 & 0,03 & 0,00 & 0,00 & 0,00 & 0,12 & 0,00 & 0,04 & \\
\hline 14 & 204 & 0,00 & 0,07 & 0,00 & 0,25 & 0,00 & 0,02 & 0,00 & 0,02 & \\
\hline 15 & 206 & 0,00 & 0,03 & 0,04 & 0,25 & 0,17 & 0,00 & 0,00 & 0,03 & \\
\hline 16 & 207 & 0,00 & 0,03 & 0,00 & 0,00 & 0,00 & 0,00 & 0,00 & 0,01 & GO-MT-MG \\
\hline 17 & 208 & 0,39 & 0,20 & 0,46 & 0,00 & 0,08 & 0,02 & 0,00 & 0,22 & \\
\hline 18 & 209 & 0,06 & 0,10 & 0,25 & 0,00 & 0,00 & 0,00 & 0,00 & 0,07 & \\
\hline 19 & 210 & 0,03 & 0,13 & 0,04 & 0,00 & 0,17 & 0,00 & 0,00 & 0,05 & \\
\hline 20 & 211 & 0,02 & 0,10 & 0,00 & 0,00 & 0,08 & 0,02 & 0,00 & 0,03 & \\
\hline 21 & 212 & 0,05 & 0,07 & 0,00 & 0,00 & 0,00 & 0,03 & 0,00 & 0,04 & \\
\hline 22 & 213 & 0,00 & 0,07 & 0,00 & 0,00 & 0,08 & 0,00 & 0,00 & 0,02 & \\
\hline 23 & 215 & 0,02 & 0,00 & 0,00 & 0,00 & 0,00 & 0,05 & 0,00 & 0,02 & \\
\hline 24 & 218 & 0,00 & 0,03 & 0,00 & 0,00 & 0,00 & 0,00 & 0,00 & 0,01 & GO-MT-MG \\
\hline 25 & 220 & 0,00 & 0,07 & 0,00 & 0,00 & 0,00 & 0,00 & 0,00 & 0,01 & GO-MT-MG \\
\hline 26 & 225 & 0,02 & 0,00 & 0,04 & 0,00 & 0,00 & 0,00 & 0,00 & 0,01 & \\
\hline 27 & 227 & 0,00 & 0,03 & 0,00 & 0,00 & 0,00 & 0,00 & 0,00 & 0,01 & GO-MT-MG \\
\hline & Total & 32 & 15 & 12 & 2 & 6 & 30 & 3 & 100 & \\
\hline
\end{tabular}




\begin{tabular}{|c|c|c|c|c|c|c|c|c|c|c|}
\hline \multirow[b]{3}{*}{ Alelo } & \multirow[b]{3}{*}{ Tamanho } & \multicolumn{5}{|c|}{ F. varia } & \multirow[b]{3}{*}{ F.t. } & \multirow[b]{3}{*}{ F.d. } & \multirow[b]{3}{*}{ Total } & \multirow[b]{3}{*}{ Privativo } \\
\hline & & \multirow[b]{2}{*}{ Campus USP } & \multicolumn{4}{|c|}{ Amostras externas ao campus } & & & & \\
\hline & & & GO-MT-MG & SP & MT & MG & & & & \\
\hline 1 & 215 & 0,00 & 0,00 & 0,00 & 0,25 & 0,00 & 0,00 & 0,00 & 0,01 & MT \\
\hline 2 & 227 & 0,00 & 0,00 & 0,00 & 0,00 & 0,00 & 0,02 & 0,00 & 0,01 & F.t. \\
\hline 3 & 228 & 0,00 & 0,00 & 0,00 & 0,00 & 0,00 & 0,02 & 0,00 & 0,01 & F.t. \\
\hline 4 & 230 & 0,44 & 0,30 & 0,69 & 0,50 & 0,17 & 0,15 & 0,00 & 0,34 & \\
\hline 5 & 231 & 0,00 & 0,07 & 0,00 & 0,00 & 0,00 & 0,00 & 0,00 & 0,01 & GO-MT-MG \\
\hline 6 & 232 & 0,19 & 0,53 & 0,12 & 0,25 & 0,25 & 0,12 & 0,00 & 0,21 & \\
\hline 7 & 234 & 0,00 & 0,00 & 0,00 & 0,00 & 0,00 & 0,13 & 0,00 & 0,04 & F.t. \\
\hline 8 & 235 & 0,00 & 0,00 & 0,00 & 0,00 & 0,00 & 0,23 & 0,00 & 0,07 & F.t. \\
\hline 9 & 236 & 0,00 & 0,00 & 0,00 & 0,00 & 0,00 & 0,00 & 0,17 & 0,01 & F.d. \\
\hline 10 & 237 & 0,00 & 0,00 & 0,00 & 0,00 & 0,00 & 0,15 & 0,00 & 0,04 & F.t. \\
\hline 11 & 238 & 0,00 & 0,00 & 0,00 & 0,00 & 0,00 & 0,02 & 0,00 & 0,01 & F.t. \\
\hline 12 & 242 & 0,00 & 0,00 & 0,00 & 0,00 & 0,00 & 0,07 & 0,00 & 0,02 & F.t. \\
\hline 13 & 243 & 0,00 & 0,00 & 0,04 & 0,00 & 0,00 & 0,00 & 0,67 & 0,02 & \\
\hline 14 & 244 & 0,03 & 0,00 & 0,00 & 0,00 & 0,00 & 0,00 & 0,00 & 0,01 & Campus USP \\
\hline 15 & 245 & 0,00 & 0,00 & 0,00 & 0,00 & 0,00 & 0,00 & 0,17 & 0,01 & F.d. \\
\hline 16 & 246 & 0,00 & 0,00 & 0,00 & 0,00 & 0,17 & 0,02 & 0,00 & 0,01 & \\
\hline 17 & 247 & 0,00 & 0,03 & 0,00 & 0,00 & 0,00 & 0,00 & 0,00 & 0,01 & GO-MT-MG \\
\hline 18 & 249 & 0,27 & 0,00 & 0,12 & 0,00 & 0,00 & 0,00 & 0,00 & 0,10 & \\
\hline 19 & 251 & 0,00 & 0,03 & 0,00 & 0,00 & 0,00 & 0,00 & 0,00 & 0,01 & GO-MT-MG \\
\hline 20 & 254 & 0,02 & 0,00 & 0,00 & 0,00 & 0,00 & 0,00 & 0,00 & 0,01 & Campus USP \\
\hline 21 & 256 & 0,06 & 0,00 & 0,00 & 0,00 & 0,00 & 0,00 & 0,00 & 0,02 & Campus USP \\
\hline 22 & 258 & 0,00 & 0,00 & 0,00 & 0,00 & 0,00 & 0,07 & 0,00 & 0,02 & F.t. \\
\hline 23 & 264 & 0,00 & 0,03 & 0,04 & 0,00 & 0,33 & 0,02 & 0,00 & 0,03 & \\
\hline 24 & 274 & 0,00 & 0,00 & 0,00 & 0,00 & 0,08 & 0,00 & 0,00 & 0,01 & MG \\
\hline & Total & 32 & 15 & 13 & 2 & 6 & 30 & 3 & 101 & \\
\hline
\end{tabular}


Apêndice 4: Trabalho aceito para publicação na revista científica Apidologie

\title{
A scientific note on the isolation and characterization of microsatellite loci of Frieseomelitta varia (Hymenoptera, Apidae, Meliponini)
}

\author{
P. H. P. Gonçalves ${ }^{1}$, F. O. Francisco ${ }^{1}$, R. M. Brito ${ }^{1}$, A. M. T. Domingues-Yamada ${ }^{1}$, F. C. Pioker ${ }^{2}$, A. \\ E. E. Soares ${ }^{3}$, M. C. Arias ${ }^{1}$ \\ 1: Departamento de Genética e Biologia Evolutiva, Instituto de Biociências, Universidade de São Paulo, \\ Rua do Matão, 277, São Paulo, SP, 05508-090, Brazil. \\ 2: Departamento de Ecologia, Instituto de Biociências, Universidade de São Paulo, Rua do Matão, \\ travessa 14, nº. 321, São Paulo, SP, 05508-900, Brazil. \\ ${ }^{3}$ : Departamento de Genética, Faculdade de Medicina de Ribeirão Preto, Universidade de São Paulo, Av. \\ Bandeirantes, 3900, Ribeirão Preto, SP, 14049-900, Brazil.
}

The environmental changes mediated directly or indirectly by humans represent a threat for many species. Most of the bee species built their nest in hollow of trees, so deforestation represents a great loss either in terms of number of species or in number of individuals (nests). The reduction of forest to fragments surrounded by urban areas may represent a severe barrier to gene flow leading to inbreeding and loss of genetic variability (Frankham et al. 2004). The assessment of the genetic structure of populations depends on the availability of reliable molecular markers. Studies aiming at characterizating stingless bees populations have been traditionally performed by using heterospecific microsatellite primers, however it has been shown that this strategy is not sensitive enough to detect polymorphism to perform robust population analysis (Francisco et al. 2006).

The stingless bee Frieseomelitta varia (Meliponini) has gotten the attention of researchers by the presence of several nests in buildings housing the University of São Paulo facilities (in Ribeirão Preto, SP). This area is surrounded by residential areas or sugar cane crop where nests have not been found. Several questions concerning inbreeding, gene flow, genetic variability can be addressed using this small population as a model. Thus aiming to answer these questions, we isolated and characterized microsatellite loci from $F$. varia genome, designed primers and standardized PCR conditions. 
Genomic DNA from a pool of 10 females was obtained following a phenol:chlorophorm protocol. The microsatellite enriched genomic library was built following the procedure described by Billotte et al. (1999). Approximately $5 \mu \mathrm{g}$ of genomic DNA were digested with $50 \mathrm{U}$ of $R s a$ I. Fragments were linked to single strand adaptors (10 $\mu \mathrm{M}$ each): - Rsa21 (5'-CTCTTGCTTACGCGTGGACTA-3') and Rsa25 (5'-TAGTCCACGCGTAAGCAAGAGCACA-3'). Those fragments were amplified by using the Rsa21 adaptor as primer. The PCR products were screened for repeat motifs through hybridization with four biotinilated probes $\left[(\mathrm{CT})_{8},(\mathrm{GT})_{8},(\mathrm{GA})_{8}\right.$ and $\left.(\mathrm{AGA})_{5}\right]$. This selection was mediated by metallic micro beads (Streptavidin MagneSphere ${ }^{\circledR}$ Promega). The selected fragments were cloned into pGem®-T vector (Promega) and used to transform E. coli DH5 $\alpha$ cells. Positive clones (71) were sequenced in an automated sequencer (ABI Prism 3100). The sequences were visualized, screened for the presence of microsatellites and aligned using the software BioEdit v. 7.0 (Hall 1999). Seventeen primer pairs were designed (see Table 1) using the software Primer3 (Rozen et al. 1998).

A sample of nineteen unrelated individuals of $F$. varia collected in different Brazilian regions was analyzed. The species Frieseomelitta flavicornis, Frieseomelitta doederleine, Frieseomelitta trichocerata, Paratrigona sp., Scaptotrigona postica, and Schwarziana quadripunctata were analyzed for cross-specific amplifications. PCR reactions were carried out in a final volume of $10 \mu$ l containing: $5.45 \mu 1$ of deionized $\mathrm{H}_{2} \mathrm{O} ; 2 \mu \mathrm{l}$ of betaine $5 \mathrm{M} ; 1 \mathrm{X}$ reaction buffer; $0.15 \mu \mathrm{l}$ of $\mathrm{MgCl}_{2} 50 \mathrm{mM} ; 0.2 \mu \mathrm{l}$ of each primer $10 \mu \mathrm{M}$; $1 \mathrm{U}$ of Taq polymerase and $1 \mu \mathrm{l}$ of template DNA obtained through phenol:chlorophorm protocol. The amplifications were performed in a GeneAmp® PCR System 9700 (Applied Biosystems) for $4 \mathrm{~min}$ at $94{ }^{\circ} \mathrm{C}$, followed by 35 cycles of $40 \mathrm{~s}$ at $94{ }^{\circ} \mathrm{C}, 50 \mathrm{~s}$ at specific annealing temperature (see Table 1), and $40 \mathrm{~s}$ at $72{ }^{\circ} \mathrm{C}$. A final elongation step of $10 \mathrm{~min}$ at $72{ }^{\circ} \mathrm{C}$ was performed. The fragments amplified were resolved by electrophoresis in polyacrylamide gels following silver staining. Observed heterozygosity $(\mathrm{Ho})$, expected heterozygosity $(\mathrm{He})$ and number of alleles were calculated using FOFpop v.2.0 (Francisco 2009). GENEPOP v.4.0 (Rousset 2008) was used to calculate Hardy-Weinberg Equilibrium (HWE) and linkage disequilibrium (LD). MicroChecker v.2.2.3 (Van Oosterhout et al. 2004) was used to perform tests for null alleles.

The amplification analysis showed that out of 17 primer pairs 12 amplified the respective loci successfully, being 11 polymorphic (Table 1). The average number of 
alleles (8.08) was the second highest found in Meliponini so far. Expected and observed heterozygosities ranged from 0.14 to 0.90 (mean 0.66 ) and from 0.00 to 1.00 (mean 0.45), respectively. In general, the observed heterozygosity was lower than the expected, except for the loci Friv5, Friv11 and Friv12 (Table 1).

Only locus Friv5 was in Hardy-Weinberg Equilibrium $(P>0.05)$. Null alleles were detected for the loci Friv1, Friv2, Friv9, Friv10, Friv14, Friv15, Friv16 and Friv18; and LD $(P<0.05)$ was detected between loci Friv1/Friv2, Friv9/Friv10, Friv2/Friv14 and Friv2/Friv18. The departure of HWE, presence of null alleles and LD observed for most of loci can be easily explained by the sampling strategy. Individuals were collected throughout the species natural geographic range (in some cases, individuals were sampled more than $1800 \mathrm{~km}$ apart). Also queen philopatry, observed in several Meliponini species can lead to population substructuring due to limited queen dispersal (Ross, 2001). This behavior, in terms of population structure can result in LD and deviation of HWE (Nei and Li 1973; Ohta 1982).

The primer set here presented is suitable for studies aiming the characterization of $F$. varia's genetic diversity, relatedness, inbreeding levels, nest aggregations, intraspecific variation and genetic mapping. Also, as the cross-species amplification tests revealed PCR fragments of expected size for the species analyzed, with few exceptions (Table 2), we are confident that those loci will be suitable and informative in population studies of other stingless bee species, and will contribute to a better understanding of the biology of $F$. varia, and for stingless bees in general.

\section{Acknowledgements}

We would like to thank Dr Anete P. de Sousa and the staff of CBMEGUNICAMP for the teachings in the construction of the genomic library; Dr Favízia Freitas de Oliveira for specimens identification; Susy Coelho Oliveira for the technical assistance; Fundação de Amparo à Pesquisa do Estado de São Paulo for the financial support (BIOTA 2004/15801-0) and for PhD scholarships to FOF and FCP; Coordenação de Aperfeiçoamento de Pessoal de Nível Superior for a Ms scholarship to PHPG and Conselho Nacional de Desenvolvimento Científico e Tecnológico for a PhD scholarship to AMTDY. 
Table 1: Name of locus, flanking primers, optimal annealing temperatures $(\mathrm{Ta})$, number of alleles $(\mathrm{K})$, allele size range, observed $\left(H_{\mathrm{O}}\right)$ and expected $\left(H_{\mathrm{E}}\right)$ heterozygosity estimated from 19 unrelated workers.

\begin{tabular}{|c|c|c|c|c|c|c|c|c|}
\hline LOCUS & REPEAT MOTIF & PRIMER SEQUENCE (5'- 3') & $\begin{array}{c}\text { Ta } \\
\left({ }^{\circ} \mathbf{C}\right)\end{array}$ & $\mathbf{K}$ & $\begin{array}{l}\text { ALLELE SIZE } \\
\text { RANGE (bp) }\end{array}$ & $\boldsymbol{H}_{\boldsymbol{O}}$ & $\boldsymbol{H}_{\boldsymbol{E}}$ & $\begin{array}{c}\text { GENBANK ACCESSION } \\
\text { NUMBER }\end{array}$ \\
\hline Friv1 & $(\mathrm{GA})_{14}$ & $\begin{array}{l}\text { F: CACACGCCTAGCCGAATTAC } \\
\text { R: GGGGAACATCTCTTGGTTCA }\end{array}$ & 64 & 13 & $210-236$ & 0.67 & 0.85 & HM222393 \\
\hline Friv2 & $(\mathrm{GA})_{10}$ & $\begin{array}{l}\text { F: GACGAATTAATCAGTCCTGGAG } \\
\text { R: GCGAGACGAGCCTCTGTT }\end{array}$ & 56 & 6 & $202-220$ & 0.12 & 0.58 & HM222394 \\
\hline Friv4 & $(\mathrm{TC})_{8}$ & $\begin{array}{l}\text { F: CGATGACACGAGCATTGACT } \\
\text { R: TCCGTCATGAATGCCAATAG }\end{array}$ & 60 & 1 & 135 & - & - & HM222395 \\
\hline Friv5 & $(\mathrm{AG})_{11}$ & $\begin{array}{l}\text { F: TAGACGTAGCCAGCGAAG } \\
\text { R: TCGATCCGTCTTCTTGGTAA }\end{array}$ & 60 & 2 & $138-140$ & 0.15 & $0.14 *$ & HM222396 \\
\hline Friv9 & $(\mathrm{TCAC})_{7} \mathrm{TCAT}(\mathrm{TC})_{15} \mathrm{TG}(\mathrm{TTTC})_{2}$ & $\begin{array}{l}\text { F: GTCGAGACGAACTTGGACGA } \\
\text { R: CGCCGCTAGTTCCCATATC }\end{array}$ & 57.5 & 8 & $198-224$ & 0.39 & 0.77 & HM222397 \\
\hline Friv10 & $\mathrm{TT}(\mathrm{TC})_{16}$ & $\begin{array}{l}\text { F: GGAACGAATCGATCTGCATTA } \\
\text { R: TATCGATCCAGCGATCCACT }\end{array}$ & 63 & 7 & $276-302$ & 0.50 & 0.77 & HM222398 \\
\hline Friv11 & $(\mathrm{GT})_{3} \mathrm{GC}(\mathrm{GT})_{10}$ & $\begin{array}{l}\text { F:AGAACGAGATCTGCCACGAC } \\
\text { R:TCACGAATCCGCTGATACAC }\end{array}$ & 60 & 2 & $222-224$ & 1.00 & 0.50 & HM222399 \\
\hline Friv12 & $(\mathrm{CA})_{17}$ & $\begin{array}{l}\text { F: TTGCCAATATCGGTCTAATCG } \\
\text { R: GACCGTTATCGTTGCAGAACT }\end{array}$ & 60 & 7 & $172-192$ & 0.78 & 0.76 & HM222400 \\
\hline Friv14 & $(\mathrm{AG})_{17}(\mathrm{G})_{3}(\mathrm{AG})$ & $\begin{array}{l}\text { F: TAATTCCACGTGTGCGTGAT } \\
\text { R: CAATTCAGGACGACCGTATG }\end{array}$ & 61 & 11 & $140-190$ & 0.11 & 0.83 & HM222401 \\
\hline Friv15 & $(\mathrm{AG})_{18}$ & $\begin{array}{l}\text { F: CGTACATACATCTGTCGAAGAACG } \\
\text { R: GCTGGCTCCTTCATTACGAG }\end{array}$ & 63 & 15 & $132-174$ & 0.58 & 0.89 & HM222402 \\
\hline Friv16 & $(\mathrm{AG})_{18}$ & $\begin{array}{l}\text { F: GCTTCTGCGTGTCAGCTC } \\
\text { R: GGCCCTCTCGTTTCCTTACT }\end{array}$ & 61 & 11 & $138-202$ & 0.42 & 0.87 & HM222403 \\
\hline Friv18 & $(\mathrm{AC})_{2}(\mathrm{GA})_{6}(\mathrm{AAAA})(\mathrm{GA})_{9}$ & $\begin{array}{l}\text { F: ATCCCACGGACGTGCTAC } \\
\text { R: CTCGTGTGTAGTCGGCTGAA }\end{array}$ & 60 & 16 & $170-204$ & 0.63 & 0.87 & HM222404 \\
\hline
\end{tabular}

*: Locus in Hardy-Weinberg Equilibrium. 
Table 2: Results from cross species amplification tests: (+) amplification and (-) no amplification.

\begin{tabular}{c|c|c|c|c|c|c}
\hline Loco & $\begin{array}{c}\text { Frieseomelitta } \\
\text { flavicornis }\end{array}$ & $\begin{array}{c}\text { Frieseomelitta } \\
\text { doederleine }\end{array}$ & $\begin{array}{c}\text { Frieseomelitta } \\
\text { trichocerata }\end{array}$ & $\begin{array}{c}\text { Paratrigona } \\
\text { sp. }\end{array}$ & $\begin{array}{c}\text { Scaptotrigona } \\
\text { postica }\end{array}$ & $\begin{array}{c}\text { Schwarziana } \\
\text { quadripunctata }\end{array}$ \\
\hline Friv1 & + & + & + & + & + & + \\
\hline Friv2 & - & - & - & - & - & - \\
\hline Friv4 & + & + & + & + & + & + \\
\hline Friv5 & + & + & + & + & + & + \\
\hline Friv9 & + & + & + & + & + & + \\
\hline Friv10 & + & + & + & - & + & + \\
\hline Friv12 & + & + & + & + & + & - \\
\hline Friv14 & + & + & + & + & + & + \\
\hline Friv15 & + & + & + & + & - & + \\
\hline Friv16 & + & + & + & + & - & + \\
\hline Friv18 & + & + & + & + & + & + \\
\hline
\end{tabular}

\section{References:}

Billotte N, Lagoda PJR, Risterucci AM, Baurens FC (1999) Microsatellite-enriched libraries: applied methodology for the development of SSR markers in tropical crops. Fruits 54:277-288

Francisco FO, Brito RM, Arias MC (2006) Alelle number and heterozigosity for microsatellite loci in different stingless bee species (Hymenoptera: Apidae, Meliponini). Neotrop Entomol 35:638-643. doi: 10.1590/S1519$566 \times 2006000500011$

Francisco FO (2009) FOFpop v.2.0, a pool of Microsoft Excel sheets to analyze genotypic data. Available at: http://www.ib.usp.br/ lgea/fofpop. Accessed 10 January 2009.

Frankham R, Ballou JD, Briscoe, DA (2004) A Primer of Conservation Genetics. Cambridge University Press, Cambridge, UK. 
Hall TA (1999) BioEdit: A user-friendly biological sequence alignment editor and analysis program for Windows 95/98/NT. Nucleic Acids Symposium Series, 41: 95-98.

Nei M, Li WH (1973) Linkage disequilibrium in subdivided populations. Genetics 75:213-219.

Ohta T. (1982) Linkage disequlibrium due to random genetic drift in finite subdivided populations. PNAS 79: 1940-1944

Ross KG (2001) Molecular ecology of social behaviour: analyses of breeding system and genetic structure, Mol Ecol 10:265-284. doi: 10.1046/j.1365294X.2001.01191.x

Rousset F (2008) GENEPOP'007: a complete re-implementation of the GENEPOP software for Windows and Linux. Mol Ecol Resour 8:103-106. doi:10.1111/j.1471-8286.2007.01931.x

Rozen S, Skaletsky HJ (1998) Primer3. Code available at http://wwwgenome.wi.mit.edu/genome_software/other/primer3.html.

Van Oosterhout C, Hutchinson WF, Wills DPM, Shipley P (2004) Micro-checker software for identifying and correcting genotyping errors in microsatellite data. Mol Ecol Notes 4:535-538. doi: 10.1111/j.1471-8286.2004.00684.x 